UNIVERSIDADE DE SÃO PAULO

FACULDADE DE FILOSOFIA, LETRAS E CIÊNCIAS HUMANAS DEPARTAMENTO DE CIÊNCIA POLÍTICA PROGRAMA DE PÓS-GRADUAÇÃO EM CIÊNCIA POLÍTICA

AUREO DE TOLEDO GOMES

\title{
DO COLAPSO À RECONSTRUÇÃO: \\ ESTADOS FALIDOS, OPERAÇÕES DE NATION- BUILDING E O CASO DO AFEGANISTÃO NO PÓS- GUERRA FRIA
}

SÃO PAULO 
UNIVERSIDADE DE SÃO PAULO

FACULDADE DE FILOSOFIA, LETRAS E CIÊNCIAS HUMANAS

DEPARTAMENTO DE CIÊNCIA POLÍTICA

PROGRAMA DE PÓS-GRADUAÇÃO EM CIÊNCIA POLÍTICA

\section{DO COLAPSO À RECONSTRUÇÃO: \\ ESTADOS FALIDOS, OPERAÇÕES DE NATION-BUILDING E O CASO DO AFEGANISTÃO NO PÓS-GUERRA FRIA}

AUREO DE TOLEDO GOMES

Dissertação apresentada ao

Programa de Pós-Graduação em

Ciência Política do Departamento de

Ciência Política da Faculdade de

Filosofia, Letras e Ciências Humanas

da Universidade de São Paulo, como

exigência parcial para a obtenção do

título de Mestre em Ciência Política.

Orientador: Profa. Dra. Rossana Rocha Reis

São Paulo

2008 


\section{BANCA EXAMINADORA:}

$\overline{\text { Profa. Dra. Rossana Rocha Reis (Orientadora) - USP }}$

Profa. Dra. Janina Onuki - USP

Prof. Dr. Luis Fernando Ayerbe - UNESP/ Araraquara

São Paulo, de de 2008. 
À minha mãe e à minha irmã, os maiores presentes que esta vida pôde me dar. 


\section{AGRADECIMENTOS}

Acredito cegamente que esta dissertação não é resultado apenas de dois anos e meio de mestrado, mas sim de toda a minha trajetória acadêmica, iniciada lá pelos idos de 2001, quando ingressei no curso de Relações Internacionais. No entanto, como o espaço é pequeno demais para agradecer a todos, além do risco de nunca conseguir fazer justiça à real contribuição de cada um, tentarei, na medida do possível, destacar aqueles que de maneira mais direta contribuíram para este trabalho.

Primeiramente, agradeço o esmero, a paciência e o empenho de Rossana Rocha Reis que soube conduzir brilhantemente o presente trabalho, sugerindo, criticando e elogiando sempre que necessário. À minha orientadora, o meu muito obrigado.

Aos professores Peter Demant e Rafael Villa, pelas valiosas contribuições durante a banca de qualificação.

À Janina Onuki e Luis Fernando Ayerbe, membros da banca de defesa, meu muito obrigado - ainda que antecipadamente - pelas sugestões e críticas que só tenderão a acrescentar qualidade a este trabalho.

Aos professores do Departamento de Ciência Política da USP, em especial Amâncio Jorge de Oliveira e Rafael Villa, pela amizade desenvolvida durante estes anos de convivência. Um agradecimento especial também aos funcionários do Departamento: Raí, Ana, Márcia, Vivian e Léo.

Aos professores da PUC-SP, agradeço pela atenção dispensada durante os meus anos de graduação. Um agradecimento especial à professora Ceres de Carvalho Medina, minha orientadora de iniciação científica e "culpada" por me colocar nos caminhos da academia.

No âmbito pessoal, à minha mãe que, além de proporcionar todo o amor e atenção e constantemente acreditar nos meus sonhos, encontrou um tempinho para fazer a revisão textual. À minha irmã, pelo amor e apoio sempre incondicionais durante toda a minha vida. À Carolina, por todo o amor e compreensão durante a reta final desta dissertação. Ao tio Ary e à tia Daphine, pela presença constante e pelos muitos almoços de domingo. Palavras não são capazes de expressar toda a gratidão que sinto por todos vocês. 
Tenho dívidas incontáveis com muitos amigos que fiz durante este percurso. Ao Eiji, Almir, Gustavo e Bruno, pela amizade, convivência e presença durante nossos anos de república. Ao Tomaz, pelo incentivo e amizade durante a realização do mestrado. A todos aqueles que junto comigo ingressaram no mestrado em 2006, em especial ao Pedro, amigo desde os tempos de graduação, e à Erica, que antes mesmo do meu ingresso no mestrado já me ajudava constantemente, ora com a bibliografia, ora com importantes conselhos.

Por último, embora de maneira fundamental, agradeço à Fundação de Amparo à Pesquisa do Estado de São Paulo (FAPESP) que, por meio da concessão de bolsa de estudo de mestrado, viabilizou a realização deste trabalho.

Enfim, se esta dissertação tem qualidades, devo à contribuição de vocês e de tantos outros. Os deméritos, no entanto, são de minha única e exclusiva responsabilidade. 
Após os atentados terroristas de Onze de setembro de 2001 os Estados Falidos passaram a ser considerados uma das principais ameaças à paz e segurança internacional. A maior parte dos estudos sobre o tema argumenta que a melhor maneira para se lidar com esta ameaça são as chamadas operações de Nation-Building, lideradas por agentes externos e cujos objetivos principais são reconstruir as instituições políticas, promover eleições democráticas e consolidar uma economia de mercado no país alvo. Assim sendo, na primeira parte do trabalho, intitulada O Colapso, esta dissertação almeja analisar as características do conceito de Estado Falido à luz do caso do Afeganistão. Na segunda parte, intitulada A Reconstrução, ambicionamos entender o que são e como são levadas a cabo as operações de NationBuilding, analisando as missões lideradas pela ONU e pelos EUA e realizando um estudo da atual operação no Afeganistão.

Palavras-chave: Estados Falidos; Nation-Building; Segurança Internacional; Afeganistão. 


\section{ABSTRACT}

After the September $11^{\text {th }}, 2001$ terrorist attacks, Failed States have been considered one of the greatest threats to peace and international security. The great majority of the studies about this theme argue that one of the best ways to cope with this threat are the so-called Nation-Building operations, leaded by external agents and whose main objectives are the reconstruction of political institutions, the promotion of elections and the consolidation of a marketoriented economy in the target country. Therefore, in the first part of this work, called The Collapse, this dissertation aims to analyze the characteristics of the Failed State concept through the Afghan case. In the second part, called The Reconstruction, we intend to understand what Nation-Building operations are and how they have been carried out, analyzing the missions leaded both by the UN and the United States and doing a case study over the current operation in Afghanistan.

Keywords: Failed States; Nation-Building; International Security; Afghanistan. 


\section{LISTA DE ILUSTRAÇÕES}

Mapa político do Afeganistão.

p. 36 


\section{LISTA DE TABELAS}

Failed States Index 2007........................................................ p. 16

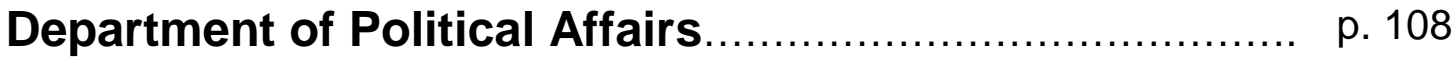

Department of Peacekeeping Operations..................... p. p. 109

Peacebuilding Support Office ................................. p. 112

Operações de Nation-Building 1945 - Hoje................... p. 136

Cultivo de Ópio no Afeganistão 1990 - 2007..................... p. p. 154

Economia política do Ópio....................................................... p. 155 
1. OS ESTADOS FALIDOS.

p. 8

1.1 A ASCENSÃO DO ESTADO.

p. 19

1.2. PARA ALÉM DA EUROPA.

p. 27

2. O AFEGANISTÃO.

p. 37

2.1 NOTAS PRELIMINARES.

p. 37

2.2 O ESTADO NO AFEGANISTÃO.

p. 38

2.3 REFLEXÕES SOBRE O ESTADO NO AFEGANISTÃO

p. 67

A RECONSTRUÇÃO.

p. 71

3. AS OPERAÇÕES DE NATION-BUILDING

p. 72

3.1 ORIGENS E ANTECEDENTES

p. 72

3.2 NATION-BUILDING: O QUE É E PARA QUE SERVE?

p. 92

4. NATION-BUILDING EM PERSPECTIVA COMPARADA. p. 104

4.1 A ONU E NATION-BUILDING. p. 105

4.2 OS EUA E NATION-BUILDING.

p. 120

5. NATION-BUILDING NO AFEGANISTÃO

p. 138

5.1 DE CABUL A BONN

p. 139

5.2 DE BONN A CABUL

p. 142

5.3 AVANÇOS E RETROCESSOS.

p. 145

5.3.1 SEGURANÇA.

p. 146

5.3.2 ECONOMIA.

p. 150 
6. CONSIDERAÇÕES FINAIS

p. 156

7. REFERÊNCIAS BIBLIOGRÁFICAS.

p. 161 


\section{INTRODUÇÃO}

"Antes de 11 de setembro, todos os sinais apontavam para o Afeganistão como uma grande ameaça para a estabilidade regional e internacional. A seca, a guerra civil, as migrações em massa, o tráfico de drogas, a linha dura imposta pelos líderes do Talibã e o aumento de grupos terroristas operando a partir do país deveriam ter alertado as potências ocidentais que uma crise estava em suas mãos ${ }^{1}$ “.

Conquanto poucos se lembrem da data exata muitos hão de se recordar das reverberações mundiais ocasionadas pelo 25 de dezembro de 1991. Neste dia, o então presidente Mikhail Gorbachev adentrou as televisões mundiais e anunciou a dissolução da URSS. O império soviético, um dos pólos de poder da Guerra Fria, desapareceria do cenário internacional deixando perplexos não apenas os teóricos de Relações Internacionais ${ }^{2}$, cuja produção foi em muito influenciada pelos anos de bipolaridade, como também os policymakers de outros países, cujas políticas externas sempre levaram em consideração a URSS. O ordenamento mundial pós-1945, caracterizado pelos embates político-ideológicos entre dois modelos de organização societal distintos e pela competição estratégico-militar entre as duas superpotências (LIMA, 1996), findara.

As conseqüências do final da Guerra Fria influenciaram sobremaneira os debates, tanto acadêmicos quanto políticos. Enquanto, no primeiro caso, grande parte da intelectualidade defrontou-se com os rumos de uma nova ordem internacional (FUKUYAMA, 1992; HUNTINGTON, 1996; WALTZ, 1999), no meio político uma das questões centrais relacionava-se com a atuação dos EUA. Única superpotência mundial em um contexto em que inexistiam novos Impérios do Mal a serem contidos e dissuadidos, como sua política externa deveria ser direcionada e quais seriam seus impactos nas relações internacionais eram apenas algumas das incógnitas (BROWN, 2001; WOLFORTH, 1999).

\footnotetext{
${ }^{1}$ RASHID, 2001: xii. Todas as traduções do inglês para o português apresentadas no decorrer do texto são de nossa responsabilidade.

${ }^{2}$ Para melhor compreensão, convencionamos diferenciar entre o nome da disciplina (Relações Internacionais) e seu objeto de estudo (as relações internacionais) pelo emprego de iniciais maiúsculas, para o primeiro caso, e minúsculas, para o segundo.
} 
Outrossim, com o fim dos anos de bipolaridade, a comunidade internacional acreditou estar à frente de um revigoramento das Nações Unidas, principalmente do Conselho de Segurança, superando a paralisia dos anos de Guerra Fria. Temas como desenvolvimento econômico e social, proteção dos direitos humanos e a manutenção da paz e segurança internacionais ganharam grande relevo. Segundo Moreno (2001), as atividades da ONU caracterizaramse neste período por um envolvimento cada vez maior em assuntos de cunho doméstico, objetivando a promoção de uma ordem internacional mais estável ${ }^{3}$.

Excetuando-se algumas análises importantes, (JACKSON e ROSENBERG, 1982; JACKSON, 1990; HELMAN e RATNER, 1992; KAPLAN, 1994) um aspecto deveras negligenciado por boa parte do mainstream acadêmico e político foi o impacto do final da Guerra Fria no Terceiro Mundo, alcunha que perdera boa parte de sua significação uma vez que a débâcle da URSS findara com o Segundo Mundo. Sabe-se que se a confrontação direta entre EUA e URSS pôde ser adjetivada enquanto fria, os embates indiretos, principalmente na África e Ásia, foram extremamente quentes. Com a vitória norte-americana, a divisão do mundo em zonas de influência não parecia ter mais utilidade, assim como teorias como a do Dominó ${ }^{4}$. As mudanças sistêmicas, oriundas do ocaso soviético, influenciaram as trajetórias de diversos países que até então eram palcos das confrontações entre as grandes potências.

caso do Afeganistão é ilustrativo. Em 25 de fevereiro de 1986, Gorbachev descrevia a intervenção soviética no país como uma ferida que não cessava de sangrar (SAIKAL, 2004). A saída da URSS do país e a queda do governo central foi o estopim para o início de uma guerra civil (1992-1996) na qual os contendores almejavam cercar Cabul e assumir o controle do país. $O$ conflito civil deteriorou ainda mais a situação do país; enquanto durante a invasão soviética os embates estiveram limitados ao interior do Afeganistão, a

\footnotetext{
${ }^{3}$ É dentro deste contexto que se inserem as discussões acerca das intervenções humanitárias. Reduzindo-se as limitações impostas pela Carta da ONU, principalmente o artigo $2^{\circ}$, parágrafo $7^{\circ}$, tais intervenções foram levadas a cabo no decorrer da década de 1990, principalmente em países acusados de desrespeito aos direitos humanos, como no caso de Kosovo. Contudo, conforme bem apontado por Alves (2003) e Koerner (2002), esta proteção dos direitos humanos era seletiva, submetida a interesses geopolíticos das principais potências.

${ }^{4}$ Grosso modo, a Teoria do Dominó asseverava que se um país saísse da zona de influência de uma das potências para a outra, a tendência seria de que outros países acompanhassem a mesma trajetória.
} 
partir de agora as facções digladiavam-se nas principais cidades, resultando num número muito maior de baixas, tanto civis quanto militares. Ademais, nenhuma das facções conseguiu fazer avanços significativos; o país podia ser visto como um grande mosaico, no qual cada região era controlada por um grupo.

Somente em 1996, com a chegada do Talibã ao poder, um grupo conseguiu ampliar consideravelmente o seu domínio pelo território afegão. Todavia, tal expansão foi caracterizada por regime fundamentalista e brutal: as minorias eram extremamente reprimidas, as mulheres eram hostilizadas e o abrigo a grupos terroristas era uma realidade que ninguém podia negar. $\mathrm{O}$ resultado de uma conjuntura tão conturbada e muito negligenciada entrou para a história como um dos maiores atentados terroristas da história, não apenas pelo número de mortos, como também pelo seu caráter emblemático: a maior potência de nossos tempos foi atacada por um grupo terrorista, o qual contara com a ajuda de um país que, até então, não tinha grande importância para a política externa dos EUA.

Da mesma forma que o Afeganistão podia ser considerado um centro de instabilidade antes dos atentados de Onze de setembro, os Estados Falidos também já eram vistos como tema importante dentro das relações internacionais, ainda que de forma não tão enfática. No Suplemento para Uma Agenda para a Paz, Boutros-Boutros Ghali (1995), então Secretário-Geral da ONU, já apontava para o fato de que uma das características dos conflitos intraestatais da década de 1990 era o colapso das instituições estatais, em particular a polícia e o judiciário, culminando numa paralisia governamental. No entanto, apenas contemporaneamente estes países passaram a receber mais saliência. De acordo com Relatório do Secretariado Geral das Nações Unidas intitulado $A$ more secure world: our shared responsibility, os Estados Fracos estão entre as seis maiores ameaças com as quais o mundo precisa lidar $(\text { UNITED NATIONS, 2004) })^{5}$. Na academia, segundo Susan Woodward, nos últimos anos construiu-se um consenso acerca da importância de tal temática. Conforme salienta a autora:

\footnotetext{
${ }^{5}$ As demais ameaças seriam (1) guerras interestatais; (2) pobreza e doenças infecciosas assim como degradação ambiental; (3) armas nucleares, químicas, radiológicas e biológicas; (4) terrorismo; e (5) crime transnacional organizado.
} 
"A ameaça primária atualmente são os Estados frágeis e em falência. Todas as ameaças concretas para a segurança internacional, incluindo terrorismo, proliferação nuclear, violações em massas dos direitos humanos, pobreza, conflitos armados $e$ refugiados são vistas como responsabilidades dos Estados e conseqüência da fraqueza estatal (2004: 01)".

Para a política externa norte-americana, o tema recebeu a devida atenção principalmente após os ataques. No documento intitulado A Estratégia de Segurança Nacional dos EUA, enviado ao congresso norte-americano em 20 de setembro de 2002, o presidente George W. Bush afirmava que:

"Os acontecimentos de 11 de setembro de 2001 nos ensinaram que Estados fracos, como o Afeganistão, podem tanto quanto os mais fortes, representar um grande perigo para nossos interesses nacionais. A pobreza não transforma os pobres em terroristas e assassinos. No entanto, a pobreza, as instituições frágeis e a corrupção podem tornar os Estados fracos mais vulneráveis às redes de terroristas e aos cartéis de drogas presentes dentro de suas fronteiras (BUSH, 2002/2003: 80)".

Tendo em mente toda esta realidade, Francis Fukuyama (2005: 124) argumenta que o falido Estado do Afeganistão estava tão fraco que foi seqüestrado por um participante não-estatal, a organização terrorista Al-Qaeda, e serviu de base para operações terroristas globais. Estas formas de ameaça, segundo o autor, não são passíveis de serem contidas por estratégias como a Contenção e a Dissuasão nuclear: diante desta nova conjuntura, a estratégia de segurança mais adequada envolveria um investimento maciço na reconstrução de Estados fracos ou falidos. As ameaças oriundas destes países assim como o receituário para lidar com os mesmos, a nosso ver, merecem alguns questionamentos importantes: 0 que é um Estado Falido e como o mesmo se torna uma ameaça à segurança internacional; e, em um outro plano, como estão sendo efetuadas as Reconstruções de Estados considerados fracassados são tópicos que merecem um maior escrutínio.

Acreditamos que a análise do caso do Afeganistão pode nos ajudar a jogar alguma luz sobre essas questões. A escolha deste país, 
contudo, não foi feita de forma aleatória. Escolhemos o Afeganistão porque sua situação interna, caracterizada pelos anos de guerra civil, passando pela ascensão do regime do Talibã, seguido das suas relações com a Al Qaeda de Osama Bin Laden influenciaram grandemente a eclosão dos atentados de Onze de setembro de 2001, realimentando o debate sobre Estados Falidos e Nation-Building. Em segundo lugar, existe um debate importante acerca do fracasso do Estado afegão: de um lado, autores como Saikal (2004) e Rubin (2002), afirmam que o país entrou em colapso antes mesmo do Talibã; outros, como Fukuyama (2005), adjudicam o fracasso à chegada da milícia e seu período no poder. Por fim, a reconstrução do país foi a primeira realizada após os atentados às Torres Gêmeas, o que nos possibilitará analisar como estão sendo levadas a cabo as atuais missões.

Não queremos, todavia, rumar para explicações simplistas. Nossa hipótese parte do princípio de que se realmente queremos entender o que é um Estado Falido não podemos nos deixar levar por análises que, como bem apontado por Hirst (2006), vilanizam a pobreza, destacando que a ineficácia de determinados países em prover bens públicos para a sua população pode acarretar no colapso de um Estado. Tais abordagens deixam a desejar ao não destacarem a dinâmica entre o país em questão e o sistema internacional. $O$ colapso do Estado longe de ser um processo endógeno, é fortemente influenciado pela forma como se deu a expansão da instituição Estado pelo globo, e, portanto, precisa ser pensado a partir de uma perspectiva mais ampla.

Assim sendo, dividimos o presente trabalho em duas etapas. A primeira parte, denominada $O$ Colapso, procura analisar como o Afeganistão enveredou para uma conjuntura que permitiu que diversos analistas 0 adjetivassem enquanto Falido. Para isso, antes de tudo, discutiremos o conceito de Estado Falido e como o mesmo foi construído e vem sendo utilizado por alguns dos principais analistas de política internacional. Nosso argumento aqui é o de que a idéia de Estado Falido só pode ser compreendida a partir de uma perspectiva comparativa, uma vez que implícita na idéia de falência está um determinado modelo de Estado moderno, cujas origens estão na Europa. Assim, temos que nos voltar para os processos históricos de construção do Estado na Europa e para a transposição dessa instituição para todo o globo, visto que esta expansão produziu diferenças qualitativas entres 
os países do sistema internacional. Dessa forma, estaremos habilitados para discutir a construção do Estado no Afeganistão e como a atuação conjunta de variáveis endógenas e exógenas criou um Estado que hoje é considerado fracassado.

$\mathrm{Na}$ seção seguinte, intitulada A Reconstrução, procuraremos avaliar o processo de reconstrução do Estado afegão, tendo em mente a atuação de dois grandes atores externos no país: os EUA e a ONU. Com esse objetivo em mente, aprofundaremos a discussão sobre a emergência do Estado fraco como uma ameaça a segurança, e de que forma esse processo se articula com uma revisão do conceito de segurança internacional. Em seguida, passaremos à questão das operações de Nation-Building, destacando as controvérsias em torna da própria definição do termo e, em particular, a forma como EUA e ONU realizam estas missões. Finalmente, após conhecimento prévio dos termos e das diretrizes que guiam as operações, teceremos algumas considerações sobre a reconstrução do Estado no Afeganistão. 
O COLAPSO 


\section{OS ESTADOS FALIDOS}

“(...) Pela natureza de sua instituição, os Estados estão destinados a viver tanto tempo quanto a humanidade, ou quanto as leis da natureza, ou quanto a própria justiça, que Ihes dá a vida. Portanto quando acontece serem dissolvidos, não por violência externa, mas por desordem intestina, a causa não reside nos homens enquanto matéria, mas enquanto seus obreiros e realizadores ${ }^{6} . "$

A ascensão e a consolidação dos Estados Falidos, como tema acadêmico e político de suma importância na agenda internacional, estão relacionadas com os efeitos do final da Guerra Fria e do Onze de setembro de 2001. Diferentemente dos anos de bipolaridade, as novas análises de política internacional, inebriadas pela euforia da década de 1990 nas quais se imaginava uma ampliação do direito internacional e das ambições normativas da sociedade internacional (HURRELL,1999), reduziram as distâncias entre High Politics e Low Politics. Dessa forma, foi possível a inclusão de temas emergentes na agenda internacional, além do impacto dessas transformações em conceitos como o de segurança, até então estritamente ligado ao Realismo.

Tal fenômeno possibilitou o surgimento de demandas visando a revisão do papel das organizações internacionais para a manutenção da ordem internacional assim como o próprio design do Estado, para que se pudesse responder de maneira mais efetiva às novas responsabilidades que a comunidade internacional reivindicava para si. As tentativas de fortalecimento de mecanismos de segurança coletiva e as regras de condicionalidade em organismos internacionais foram apenas alguns dos movimentos na direção de um Solidarismo Coercitivo, designação dada por Hurrell (1999).

Dentro dessa conjuntura maior notamos a ascensão da temática envolvendo os ditos Estados Falidos. Pioneiro, Saving Failed States, de Helman e Ratner (1992), argumentava que os Estados Falidos, caracterizados por conflitos civis, falência governamental e privações econômicas, conforme tornam-se palcos para violência intestina e anarquia, colocam seus próprios cidadãos em perigo além de propiciar instabilidade regional. Salvar os Estados

\footnotetext{
${ }^{6}$ HOBBES, 1997: 243
} 
Falidos, segundo os autores, seria o desafio a ser enfrentado pela comunidade internacional.

I. William Zartman (1995), em seu artigo na coletânea Collapsed States: The Disintegration and Restoration of Legitimante Authority, postula que o colapso estatal é um fenômeno mais profundo do que rebeliões e golpes de estado. De acordo com seu raciocínio, o colapso estatal se refere a uma situação aonde a estrutura, a autoridade (poder legítimo), a lei e a ordem política foram destruídas e precisam ser reconstruídas de alguma forma (1995:01). Segundo Zartman, os Estados entram em colapso porque:

\begin{abstract}
"Não conseguem mais realizar as funções que os caracterizam enquanto Estados. Um Estado é a instituição de autoridade política soberana sobre determinado território. Esta definição salienta três funções: o Estado enquanto autoridade soberana - a fonte reconhecida de identidade e a arena da política; o Estado enquanto instituição - e, consequentemente, uma organização tangível de tomada de decisões e um símbolo intangível de identidade; e o Estado enquanto garantidor da segurança para sua população (1995:05)".
\end{abstract}

Destarte, o colapso significa que as funções básicas do Estado não são mais desenvolvidas. Enquanto centro de tomada de decisões, o Estado está paralisado e inoperante: leis não são feitas, a ordem não é preservada e a coesão societal está comprometida. Enquanto símbolo de identidade, o Estado perde seu poder de conferir nome à sua população e sentido para a sua ação social. A segurança não é mais assegurada a todo o território e o sistema socioeconômico tem seu funcionamento totalmente comprometido. Por fim, parafraseando Weber (2004), sem fontes tradicionais, carismáticas ou racionais-legais de legitimação, o Estado perde a capacidade para governar.

Após os ataques terroristas de 11 de setembro de 2001 uma nova leva de autores procurou lidar com a temática dos Estados Falidos dentro das Relações Internacionais. Além do já destacado Fukuyama (2005), um projeto desenvolvido pela Harvard University, encabeçado por Robert I. Rotberg, objetivou analisar a falência dos Estados no pós-Guerra Fria, dando origem à 
artigos (ROTBERG, 2002) e à uma coleção de livros (ROTBERG, 2003; ROTBERG, 2004; ROTBERG, 2007). Seguindo a linha desenvolvida pelo autor e seus colaboradores:

"Estados-Nação fracassam quando são consumidos por violência interna e deixam de prover bens públicos aos seus habitantes. Seus governos perdem credibilidade e a natureza dos Estados torna-se questionável e ilegítima nos corações e mentes dos cidadãos (2004:01)".

Os Estados existem, segundo Rotberg (2003), para proverem um método descentralizado de entrega de bens políticos públicos para as pessoas que vivem dentro de suas fronteiras. Estes bens políticos são aqueles clamores intangíveis e difíceis de quantificar que os cidadãos outrora faziam aos monarcas e que agora são feitos para os Estados. Eles englobam direitos e deveres dos cidadãos e são o substrato do contrato social entre governante e governados. Na hierarquia de bens políticos públicos apresentada por Rotberg, a segurança, em especial a segurança humana, encabeça a lista, seguida pelos direitos políticos, civis e sociais ${ }^{7}$, além temas como infra-estrutura, comércio, educação e saúde.

Fukuyama, em seu Construção de Estados (2005), percorre direção semelhante, argumentando que o Estado possui três tipos de funções. Dentre as Funções Mínimas, destacam-se a provisão de bens públicos, em especial defesa, lei, ordem, direitos de propriedade, saúde pública, entre outros. Por Funções Intermediárias, devemos ter em mente cuidados com educação, meioambiente, regulamentação financeira e assim por diante. Finalmente, nas Funções Ativistas, encontramos quesitos como política industrial e redistribuição de riqueza. De modo esquemático, Ghani, Lockhart e Carnahan (2005) dividem em 10 as principais funções do Estado moderno ${ }^{8}$, quais sejam:

\footnotetext{
${ }^{7}$ Para as questões envolvendo cidadania e direitos políticos, civis e sociais, sugere-se Marshall (1967) e Bobbio (2004).

${ }^{8} \mathrm{O}$ debate acerca de quais funções o Estado deve ter é bastante variado, desde aqueles que argumentam que o Estado deve se engajar na formulação e execução de políticas desenvolvimentistas (por exemplo, a escola da CEPAL) enquanto outros, principalmente as abordagens de cunho mais liberal (KRUEGER, 1990), advogam uma atuação mais limitada, pregando maior espaço para os mecanismos de mercado.
} 
01. Monopólio dos meios de violência dentro de determinado território;

02. Controle administrativo;

03. Administração das finanças públicas;

04. Investimento em capital humano;

05. Delineação dos direitos e deveres da população;

06. Provisão de infra-estrutura;

07. Formação do mercado interno;

08. Administração dos bens do Estado (recursos naturais, culturais, etc.)

09. Relações internacionais;

10. Estabelecimento do Estado de direito.

Segundo os autores, o fracasso em prover uma ou mais dessas funções pode redundar em conseqüências perigosas. Pode-se criar um círculo vicioso resultando no surgimento de centros de poder contestadores; na multiplicação de processos de formulação e de execução de políticas públicas ineficazes; na perda da confiança dos cidadãos no Estado; na deslegitimação das instituições; no fim da cidadania; e, por fim, no surgimento de conflitos dentro do país (GHANI, LOCKHART e CARNAHAN, 2005: 09).

As questões envolvendo a distribuição dos bens públicos e as funções desempenhadas são nevrálgicas para os autores porquanto oferecem os critérios para que julguemos o desempenho estatal. Segundo Rotberg (2004), existiria uma taxionomia distinguindo quatro tipos de Estado, baseada neste desempenho:

- Estados fortes: seriam aqueles que controlam seus territórios e proporcionariam uma grande gama de bens públicos para sua população;

- Estados fracos: possuiriam clivagens étnicas e/ou religiosas capazes de desencadearem um conflito. Ademais, sua capacidade para distribuir bens públicos seria mais limitada.

- Estados falidos: proporcionariam uma quantidade limitada de bens públicos essenciais, como saúde, educação e 
segurança. Progressivamente tais bens passariam a ser distribuídos por atores não-estatais, como senhores tribais, grupos religiosos e terroristas. O legislativo apenas ratificaria as decisões do executivo enquanto o judiciário seria apenas uma extensão do soberano. A infra-estrutura do país estaria comprometida e a economia privilegiaria uma oligarquia próxima ao poder.

- Estados em colapso: seriam versões extremas de estados falidos. Não haveria autoridade alguma dentro do território, os bens públicos seriam obtidos via meios privados e a segurança seria a lei do mais forte. ${ }^{9}$

Conquanto a provisão de bens públicos seja um dos critérios para se avaliar o desempenho e diferenciar os Estados, não é o único encontrado. Buzan e Little (2000) destacam a importância da coesão sócio-política (apesar de não definirem o que seja isto) e da forma de governo na análise das capacidades estatais. Segundo os autores:

"Estados Fracos são aqueles com níveis baixos de coesão sóciopolítica. Porquanto falharam em integrar sociedade e governo, normalmente apresentam governos autoritários e violentos conflitos internos. Na outra ponta do extremo, Estados Fortes possuem altos grados de coesão sócio-político, são democráticos e tendem a apresentar uma política doméstica pacífica (2000: 255)".

Migdal (1988), ao estudar as relações entre Estado e sociedade, argumenta que o desempenho de um Estado deve ser avaliado segundo suas capacidades para penetrar na sociedade, regulamentar as relações sociais, extrair recursos e se apropriar de tais recursos e usá-los de determinadas

\footnotetext{
${ }^{9}$ Com objetivo semelhante, Clément (2005) diferencia Estados em colapso daqueles em crises e dos ditos Estados fortes. Segundo a autora, um Estado em colapso apresenta sérias dificuldades para lidar com conflitos e impor a segurança e é incapaz de prover serviços essenciais e infra-estrutura básica para boa parte de seu território durante um período substancial de tempo. Já um Estado em crise seria aquele com dificuldades para lidar com conflitos e impor segurança, além de não distribuir serviços essenciais e infra-estrutura básica para poucos recantos de seu território durante um período pequeno. Por fim, o Estado forte seria aquele que resolve conflitos internos e consegue projetar segurança e prover serviços essenciais e infra-estrutura para parte substancial de seu território durante um período contínuo de tempo (CLÉMENT, 2005:4-5).
} 
maneiras e para determinados fins. Logo, Estados Fortes são aqueles com capacidade alta para desempenhar tais tarefas enquanto Estados Fracos são aqueles que deixam a desejar em tais quesitos. Por fim, o Crisis States Research Centre, ligado à London School of Economics, apresenta algumas definições acerca de tal temática, as quais culminam na seguinte lista (2006: 01):

- Estado Frágil: é aquele suscetível à crises. Os arranjos institucionais corporificam e preservam as condições de crises. Economicamente, as instituições reforçam estagnação, baixas taxas de crescimento e desigualdade; em termos sociais, as instituições podem aumentar as desigualdades sociais e dificultar o acesso à saúde e educação, por exemplo; por fim, politicamente falando, tais Estados podem favorecer determinadas facções e excluir o grosso da população do poder.

- Estado em Crise: é aquele em que suas instituições enfrentam sérias contestações e são impotentes frente à conflitos e choques externos.

- Estado Falido: é o Estado que não desempenha mais funções básicas, tais como segurança, e que não mantém o controle efetivo de seu território e de suas fronteiras.

A partir dessa breve revisão da bibliografia acerca do fracasso estatal $^{10}$, já podemos destacar alguns dos problemas presentes nessa discussão. Quando caracterizamos um Estado enquanto forte ou fraco, falido ou em colapso, devemos especificar em relação ao que e a quem tal Estado fracassou. Assim sendo, conforme apontam Milliken e Krause (2002), a falência estatal está relacionada com as tarefas que o Estado moderno deveria realizar e que alguns países não conseguem executar.

Segundo as análises supracitadas, o provimento de bens públicos por parte dos Estados é o principal critério levado em consideração para a

\footnotetext{
${ }^{10}$ Para uma boa revisão da literatura acerca dos Estados Falidos, sugere-se Monteiro (2006).
} 
qualificação de um país enquanto falido. Rotberg (2004) afirma que uma vez garantida a segurança dentro do território e com o monopólio da violência legítima também assegurado, o país pode oferecer outros bens, tais como direito de participação política, liberdades religiosas, saúde, saneamento básico, educação e infra-estrutura. Ou seja, como fazer o Estado voltar a prover tais bens e deixar de causar instabilidade para os países vizinhos é a principal preocupação destas análises.

O periódico Foreign Policy, em associação com o Fund for Peace, por três anos consecutivos veicula o Índice de Estados Falidos, um catálogo que vem sendo amplamente utilizado nas discussões sobre o tema. $O$ índice, assim como a classificação utilizada por Rotberg, compartilha a concepção de Segurança Humana, conceito que apareceu pela primeira vez no relatório sobre Desenvolvimento Humano do Programa de Desenvolvimento das Nações Unidas, em 1994. Ao colocar os indivíduos como sujeitos a serem assegurados em detrimento do Estado, estas análises colocam do mesmo lado países como o Afeganistão e Iraque, cujos governos são constantemente contestados, e Coréia do Norte, China e Rússia, países que conseguem projetar poder sobre todo território. Dentre os principais indicadores de fraqueza estatal propostos pela Foreign Policy encontramos Pressões Demográficas, Refugiados e Pessoas Dispersas Internamente, Crescimento econômico desigual entre grupos, Deterioração de Serviços Públicos e Criminalização e Deslegitimação do Estado.

$\mathrm{Na}$ edição de julho/agosto de 2007, no lançamento do último índice, a revista afirmou que o fenômeno da falência estatal, a despeito de ser extremamente discutido, ainda é pouco entendido. Os problemas que afligem tais países são similares, indo desde aumento da corrupção, elites predatórias que monopolizam o poder, ausência do Estado de Direto, culminando em severas divisões étnicas e religiosas. Ainda que salientem que fatores como desastres naturais, choques econômicos e fluxos de refugiados de países vizinhos possam aumentar a suscetibilidade à falência estatal, quiçá a mais importante explicação causal sejam as más lideranças que administram os governos. Segundo a reportagem, muitos Estados sofrem devido à pobreza, corrupção e desastres naturais. Contudo, para os mais fracos, não há nada mais custoso que lideranças fortes comandando a seu bel-prazer (Foreign 
Policy, julho/agosto 2007). Trajetória similar é salientada por Krasner (2004) ao afirmar que pobreza, instituições fracas, insegurança e a maldição das matérias-primas seriam as principais causas do fracasso estatal.

A literatura sobre o fracasso dos Estados, todavia, se dedica muito menos às origens do fenômeno do que à busca de soluções, uma vez que os Estados Falidos são cada vez mais vistos como empecilho para o desenvolvimento dos países do centro, gerando fluxos de refugiados, terrorismo e tráfico de drogas. Mutatis mutandis, conforme Ayerbe (2006: 184), a revalorização da ação estatal está fortemente condicionada pelas convulsões que ameaçam a governabilidade nas periferias subdesenvolvidas, com seus efeitos colaterais no capitalismo avançado. Ademais, as publicações sobre o tema partem do pressuposto - ainda que implícito - de que o Estado nos países ditos liberais-desenvolvidos é um construto acabado, que não precisava de nenhuma emenda. As falhas que esses países apresentam em nenhum momento são questionadas e a mensuração sobre o êxito ou a falência restringe-se à observações sobre as capacidades coercivas dos Estados. 
Failed States Index $2007^{11}$

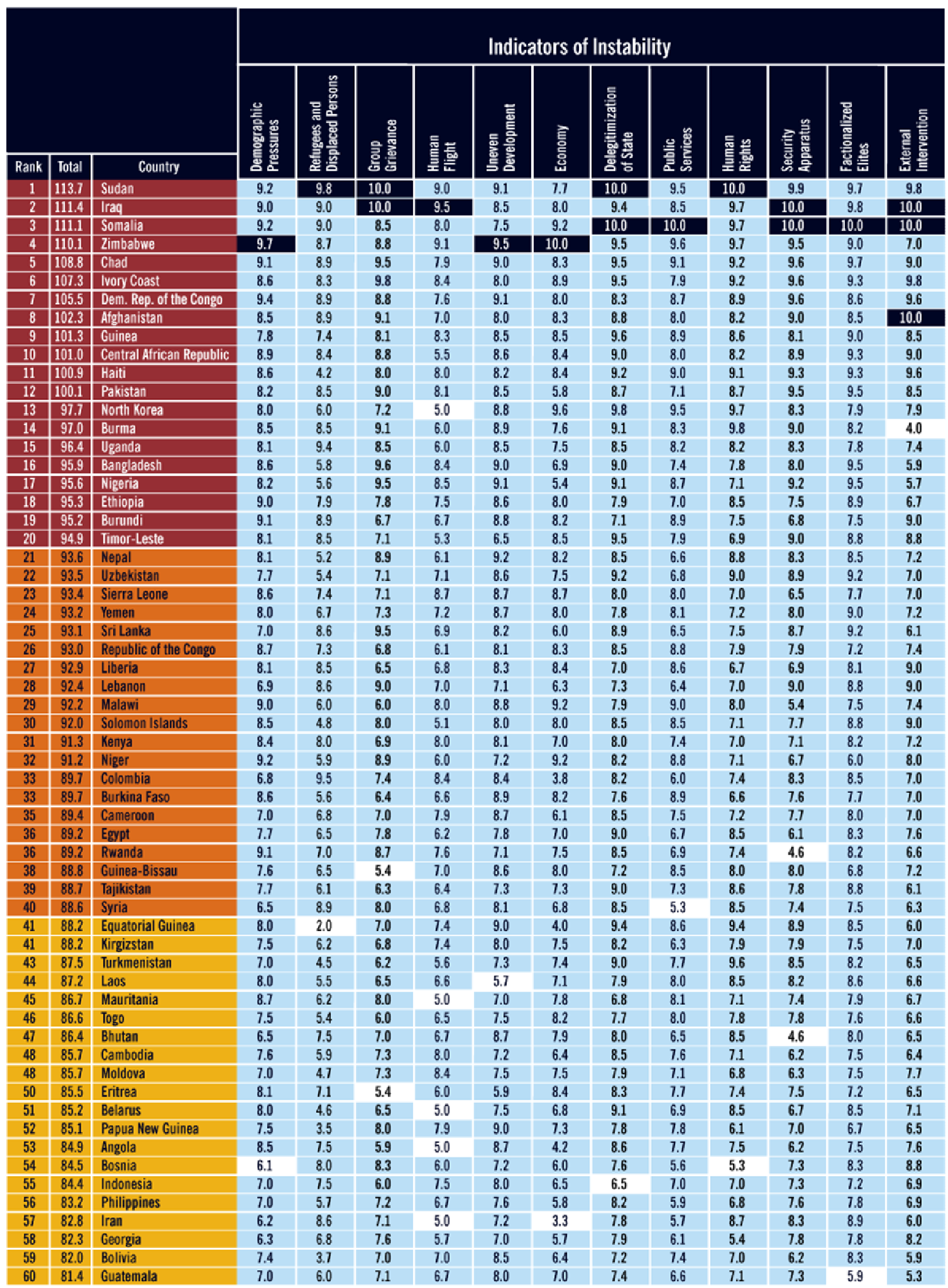

Ao negligenciar as origens dos problemas dos países da periferia, essas abordagens tomam a situação destes países como dadas e tendem a

\footnotetext{
${ }^{11}$ Disponível em www.fundforpeace.org. Acesso em 12/11/2007
} 
reificá-las, criando a idéia de que eles foram sempre assim e que serão sempre assim. A maior parte das análises, ainda que façam um diagnóstico preciso da situação dos países em questão, jogando luz sobre as principais dificuldades encontradas em campos que vão desde a segurança, infra-estrutura e organizações políticas, pressupõem que existe ou existiu em algum momento da história de tais países um Estado semelhante àquele encontrado na Europa Ocidental ou nos EUA, desconsiderando todas as peculiaridades históricas dos países em questão. $O$ impacto de questões como as intervenções perpetradas pelas grandes potências, assim como a expansão do capitalismo e do colonialismo pelo globo não são levadas em consideração.

O conceito de Estado Falido encerra dois pressupostos básicos (PUREZA ET AL et al, 2007; e PUREZA et al, 2006): os Estados fracassam porque não possuem as capacidades institucionais, econômicas e políticas para sobreviver enquanto Estados soberanos; e a falta de tais capacidades se deve sobretudo à problemas de governança interna. Estes seriam os motivos que permitiriam aos analistas, parafraseando Zartman (1995:08), classificarem o colapso estatal como uma doença degenerativa de longo prazo. Indo na direção proposta por Woodward (2004), notamos a presença em boa parte da literatura sobre o tema de um modelo normativo de Estado: o Estado liberaldemocrático, favorável aos ditames do mercado, transparente e responsivo (accountable), com instituições muito específicas. Ademais, ainda conforme Woodward:

\begin{abstract}
"No geral, Estados são necessários para segurança empiricamente, pesquisas nos dizem isto; normativamente, as unidades do sistema internacional são os Estados e o sistema é organizado de acordo com o princípio da soberania; $e$ conjunturalmente, estamos enfrentando as conseqüências nos Estados frágeis e falidos das tensões entre esforços sistemáticos para reduzir os tamanhos dos mesmos nos últimos 25 anos e, de outro lado, no aumento das demandas para o Estado lidar com as ameaças à segurança internacional (2004:04)".
\end{abstract}

Em sentido similar caminha Pureza et al (2006), quando afirmam que Estado Falido é um conceito negativo, ou seja, refere-se a algo que não 
está explícito. O que está implícito no conceito é o arquétipo do Estado moderno weberiano, aquele que, dentro de determinado território, reivindica 0 monopólio do uso legítimo da violência física (WEBER, 2004) e que tem sua gênese na Europa no século $X V I^{12}$. Estas características das análises salientam o eurocentrismo do conceito: não existiriam melhores alternativas para a organização política da população e para o relacionamento entre os países do que um Estado aos moldes ocidentais. Mutatis mutandis, o diferente não é bem visto, a homogeneidade deve prevalecer e todos os países do globo devem emular o modelo ocidental.

O Estado, assim como o sistema estatal do qual faz parte, é uma instituição histórica, construída pelos homens em determinada época (JACKSON e SORENSEN, 2007), e não um dado inerente da realidade. Conforme bem salientado por Pureza et al (2007), as principais análises acerca dos Estados Falidos deixam de lado esta variável histórica, concentrando-se em temas como a qualidade (ou a falta de) das lideranças internas como possíveis causas para a falência estatal. Negligenciando a história, alguns analistas deixam escapar temas importantes, que em nosso entender deveriam ser integrados a analise, ora 0 avanço do colonialismo sobre partes consideráveis do globo (FERRO, 1996), ora a influência que as potências tiveram na configuração do atual sistema de Estados (JACKSON, 1990).

Assim sendo - e tendo-se em mente que o próprio conceito de Estado Falido encerra esta comparação entre o Estado moderno e as funções que tal entidade é capaz de desempenhar, e aqueles países que não conseguiram atingir tal zênite - acreditamos ser importante mostrar as particularidades da ascensão do Estado na Europa e sua expansão pelo mundo. Não se trata de traçar toda a genealogia de tal entidade ${ }^{13}$, tampouco mostrar toda a história do avanço da Europa sobre as demais partes do globo. Queremos explicitar quais processos resultaram na ascensão e consolidação

\footnotetext{
${ }^{12}$ Por vezes, o conceito contrário encontra-se explícito. Segundo as definições propostas pelo Crisis States Research Centre (2006:01), o contrário do Estado Frágil seria o Estado Estável (Stable State), aquele em que os arranjos institucionais são capazes de confrontar choques internos e externos. Por sua vez, o contrário do Estado em Crise seria o Estado Resiliente (Resilient State), aquele que após uma forte pressão devido à conflitos internos e/ou ameaças externas consegue retomar o formato original de suas instituições. Finalmente, o contrário do Estado Falido é o Estado Duradouro (Enduring State), cujas instituições permanecem mesmo após os períodos de crises.

${ }_{13}$ Para uma genealogia do Estado, sugere-se Creveld (2004).
} 
do Estado moderno, pois entendemos que identificar as linhas mestras que transportaram o Estado do Velho Continente para o restante do globo são de fundamental para a compreensão dos Estados Falidos. Por meio do exemplo do Afeganistão, esperamos contribuir para um melhor entendimento deste fenômeno.

\subsection{A ASCENSÃO DO ESTADO}

Num intervalo de aproximadamente cinco séculos, muitas formas de organização política, fossem elas tribos, Impérios e/ou Cidades-Estados, acabaram sendo superadas pelo Estado moderno. Nosso objetivo aqui é entender quais foram os processos que permitiram a esta entidade surgir e conseguir alcançar todos os quadrantes do sistema internacional ${ }^{14}$.

Em sua clássica definição, Weber (2004b) salienta três elementos principais para a caracterização do Estado, quais sejam, (1) a existência de um suporte administrativo regular e capacitado; (2) a sustentação do direito de monopólio legítimo do controle dos meios de violência; e (3) a manutenção desse dispositivo dentro de um território. Ademais, a dominação política foi progressivamente despersonalizada, formalizada e racionalizada, deixando de ser parte dos atributos do soberano. Segundo Charles Tilly (1996: 199), Estado é uma organização distinta que controla os principais meios concentrados de coerção dentro de um território bem definido, e em alguns aspectos exerce prioridade sobre todas as outras organizações que operam dentro do mesmo território. Por fim, Skocpol (1985: 42) argumenta que:

\footnotetext{
${ }^{14}$ O conceito de sistema internacional apresenta definições distintas. Marcel Merle (1981) afirma que este seria o meio, cuja característica essencial é a anarquia, no qual se processam as relações entre os diferentes atores que compõem e fazem parte do conjunto das interações sociais que se processam na esfera do internacional. Por sua vez, Hedley Bull (2002) argumenta que quando dois estados mantêm contato regular entre si e quando o comportamento de cada um deles é fator necessário nos cálculos do outro, pode-se dizer que formam um sistema. Raymond Aron (2002) caracteriza o sistema internacional como o conjunto constituído pelas unidades políticas que mantêm relações regulares entre si e que são suscetíveis de entrarem numa guerra geral. Das conceituações acima, desprende-se a noção de que quando se fala de sistema internacional, trata-se de caracterizar o espaço de convivência entre atores internacionais e 0 conjunto de elementos que regulam 0 comportamento dos mesmos.
} 
"O Estado não é uma mera arena aonde se disputam as lutas socioeconômicas, mas sim um conjunto de organizações administrativas, políticas e militares encabeçadas. E, mais ou menos coordenadas por uma autoridade executiva. Qualquer Estado, antes de mais nada e fundamentalmente, retira recursos pecuniários da sociedade e aplica-os na criação e manutenção de organizações coercivas e administrativas". ${ }^{15}$

Este construto acima definido emergiu na Europa dos escombros do Feudalismo a partir do século XVI. As monarquias centralizadas da França, Inglaterra e Espanha representaram uma grande ruptura frente à soberania piramidal e parcelada das formações sociais existentes na Idade Média ${ }^{16}$, findando com mecanismos como a vassalagem feudal. Segundo Elias (1993), uma característica fundamental do período de ascensão do Estado é o chamado processo de monopolização. Seguindo seu raciocínio, o livre emprego de armas militares é reservado apenas para a autoridade central e vedado aos demais indivíduos, assim como o direito de tributar. Temos, no entanto, um fenômeno de mão-dupla: se, de um lado, os recursos pecuniários angariados pelo Estado sustentam-Ihe o monopólio militar, este, por sua vez, garante-Ihe a tributação.

As grandes unidades sociais do Feudalismo eram constituídas por unidades menores, que por meio das suas relações, constituíam a maior. Inicialmente, todas possuíam capacidades similares e podiam competir livremente umas com as outras dentro do território em questão, uma vez que inexistiam monopólios prévios. Como salientado por Elias (1993), desta competição era alta a probabilidade de que algumas unidades lograssem vencer as demais e, consequentemente, um número cada vez menor de

15 Reconhecemos que as definições pelas quais optamos apresentam um viés Neoinstitucionalista, deixando de lado abordagens importantes como o Pluralismo e o Marxismo. Tal opção, contudo, se deve ao fato de que a literatura sobre os Estados Falidos, conforme apresentada anteriormente, se aproxima mais no Neoinstitucionalismo, porquanto destaca a importância das instituições estatais para o entendimento do Estado. Para uma abordagem pluralista do Estado sugerimos Dahl (1961) e para um viés marxista, Poulantzas (1985 e 1986) e Lenine (1986). Para uma introdução ao Neoinstitucionalismo, Hall e Taylor (2003) e para uma revisão bibliográfica sobre as diferentes abordagens relativas ao papel do Estado, Marques (1997).

${ }^{16}$ Engels (apud Anderson, 2004: 37) caracteriza a soberania do período com o exemplo da Borgonha. Segundo o autor, Carlos, o Temerário, era vassalo do imperador por uma parte de suas terras, e vassalo do rei francês por outra; por outro lado, o rei da França, seu suserano, era ao mesmo tempo vassalo de Carlos, o Temerário, seu próprio vassalo quanto a certas regiões. 
indivíduos passasse a controlar uma quantidade maior de homens e terra. Este processo de competição levado ao seu limite culminaria, segundo o autor, numa configuração em que um único indivíduo controlaria todas as possibilidades de poder e todos os demais passariam a depender dele.

Se, por um lado, um único indivíduo monopoliza todas as possibilidades de poder (consubstanciadas aqui por terra, soldados e dinheiro), a tendência é que se torne cada vez mais difícil para que ele próprio supervisione suas propriedades. Logo, surge a necessidade de delegar poderes aos seus dependentes para a supervisão de seus territórios. De acordo com Elias (1993: 101):

"Em outras palavras, quanto mais abrangente se torna a posição monopolista e mais altamente desenvolvida a divisão do trabalho, com mais clareza e certeza ela se moverá para um ponto em que 0 governante monopolista (seja ele um só ou um grupo) se tornará o funcionário central de uma máquina composta de funções diferenciadas, mais poderosa do que outras, talvez, mas pouco menos dependente e agrilhoada. (...) De uma forma ou de outra, o poder central inicialmente adquirido através da acumulação de oportunidades em lutas privadas tende, a partir de um ponto assinalado pelo tamanho ótimo das posses, a escorregar das mãos dos governantes monopolistas para as mãos dos dependentes como um todo ou, para começar, para grupos dependentes, tais como a administração monopolista. O monopólio privadamente possuído por um único indivíduo ou família cai sob o controle de um estrato social mais amplo e se transforma, como órgão central do Estado, em monopólio público".

Em um ambiente como este, a livre competição entre as partes é uma luta entre muitos concorrentes por recursos os quais ainda não foram monopolizados. O surgimento de tal estrutura é precedido por este tipo de prova eliminatória (ELIAS, 1993: 103) e a vitória de uma parte significa a perda de outrem e sua redução a um estado de dependência. Não obstante, cedo ou tarde, a vitória significaria o embate com um adversário de envergadura comparável. Dessa forma, a única saída possível é a expansão contínua, e, por 
conseguinte, a absorção, subjugação, humilhação ou destruição dos contestadores.

Nesse sentido, nos deparamos com a afirmação de Charles Tilly, segundo a qual a guerra fez os Estados (2002: 170). Esmiuçando seu argumento, as guerras que corroeram a Europa no período estudado pelo autor (990-1992) obrigaram todos os governantes a organizarem exércitos e marinhas e, para tanto, era preciso extrair recursos e homens de sua população para o funcionamento de tais instituições. Por sua vez, a criação destes novos órgãos permitiu que os governantes aumentassem o controle sobre suas populações e territórios de formas mais rigorosas.

Consoante ao argumento de Elias (1993), Tilly (1996) afirma que os governantes tentaram defender e ampliar seu domínio sobre populações e territórios. Além disso, a ameaça constante de outros Estados com objetivos semelhantes fez com que grande parte dos governantes europeus enveredasse para guerras. Todavia, para arcar com os custos de tal empreitada, os governantes tiveram que extrair os recursos necessários de sua população, a qual na maioria das vezes era extremamente reticente. Em regiões em que prevalecia o comércio ou, como afirma o autor, onde a concentração de capital era grande (Veneza e Gênova, por exemplo) os governantes podiam obter recursos mediante a tributação comercial e empréstimos. No outro extremo, em regiões com alta concentração de coerção, os governantes tiveram que recorrer à extração coercitiva para obter os recursos. Menos eficiente, dependia de grande quantidade de funcionários e da ajuda de senhores rurais os quais controlavam boa parte dos meios de coerção (o caso russo e sueco, segundo Tilly, são os melhores exemplos).

Nos territórios em que havia uma combinação de senhores rurais e cidades comerciais encontramos os melhores exemplos de Estados que conseguiram não apenas se manterem em uma conjuntura de guerras contínuas, mas também se expandiram. Os governantes de tais regiões conseguiram maior autonomia jogando ora com os senhores rurais, ora com os comerciantes: utilizaram o capital disponível para instituir grandes forças militares e subjugar os aristocratas armados pari passu à criação de contingentes consideráveis oriundos da população rural para controlar as cidades. Este processo culminou na criação de exércitos permanentes e 
burocracias que nem os terratenentes nem os capitalistas conseguiam controlar. Conforme seu raciocínio (1996: 68-69):

"A preparação da guerra, sobretudo em larga escala, envolve os governantes inelutavelmente na extração. Constrói uma infraestrutura de tributação, abastecimento e administração que requer a manutenção própria e muitas vezes cresce mais depressa que os exércitos e marinhas para cujo serviço foi instituída; aqueles que administram a infra-estrutura adquirem poder e interesses próprios; seus interesses e poder limitam consideravelmente o caráter e a intensidade da guerra que qualquer Estado particular pode empreender"

Por conseguinte, não só os meios militares, mas também a burocracia administrativa tornam-se extremamente importantes para 0 funcionamento do Estado. Os Estados uniram, numa mesma estrutura central relativamente coordenada, organizações militares, extrativas e administrativas. Tais máquinas sagraram-se vencedoras nas guerras que empreenderam e angariaram controle substancial sobre seus territórios e populações e, assim sendo, a partir do século XVII, todos os governantes que almejassem sobreviver precisaram emular este modelo ${ }^{17}$.

Além da pressão que o ambiente externo exercia sobre os governantes para que transformassem o aparato de seus Estados, temos que considerar a grande influência que o capitalismo teve na formatação dos Estados modernos. Segundo Giddens (2001), no capitalismo, caracterizado pela divisão da sociedade em classes e no qual o conflito entre elas é a variável estruturante da vida social, na medida em que se estabelecem relações próximas entre as classes existentes faz-se necessário a vigilância ${ }^{18} \mathrm{e}$ a pacificação interna do Estado, para que convulsões intestinas não afetem o funcionamento da economia. Conforme palavras do próprio autor (2001: 181):

\footnotetext{
17 Tilly assevera que com o passar do tempo e com o aumento da escala e dos custos da guerra, as negociações com os diversos setores da população para a manutenção do Estado tornaram-se cada vez mais difíceis. Uma das conseqüências foi o surgimento e ampliação dos direitos de cidadania e representação, resultado das exigências da população para a cooperação frente às guerras.

${ }^{18}$ A vigilância em Giddens tem dois sentidos: além da supervisão direta deve ser também entendida enquanto acumulação de informações codificadas.
} 
"No capitalismo industrial há o desenvolvimento de um novo tipo de sistema de classe, no qual a luta de classes é predominante, mas em que também a classe dominante - aqueles que detêm ou controlam grande volume de capital - não tem ou não pedem acesso direto aos meios de violência para manter seu domínio. Ao contrário dos sistemas anteriores de dominação de classe, a produção envolve relações próximas e contínuas entre os principais agrupamentos de classes. Isso presume uma 'duplicação' à vigilância, os modos de vigilância tornando-se um aspecto chave das organizações econômicas do próprio Estado. O processo que - na falta de expressão melhor - pode ser chamado de pacificação interna de Estados é uma parte inerente da crescente coordenação administrativa que marca a transição do Estado absolutista para 0 Estado-nação".

A pacificação interna dos Estados e o concomitante aumento de suas unidades administrativas estão relacionados com diversos fatores, desde a mecanização do transporte e a expansão das atividades documentais do governo, cuja ampliação na forma de coletar informações para propósitos administrativos, aumenta o escopo das atividades estatais para os mais diversos âmbitos da sociedade. As atividades sociais passam a ser observadas regularmente para que possam ser mais bem controladas. A expansão do poder administrativo, em especial a vigilância sobre a população, diminuiu a dependência do Estado em relação aos meios de violência enquanto instrumento para a dominação da sociedade e permitiu a emergência de instituições especializadas, tais como o policiamento interno, que teriam como uma de suas principais funções lidar com o criminoso, aquele que deve ser ajustado às normas de comportamento aceitáveis pelas obrigações da cidadania, e direcionando a atenção do exército para o meio internacional. Dessa forma, como bem apontado por Xavier (2006), a construção dos Estados é um processo multidimensional, envolvendo a inserção e reprodução da organização política no sistema internacional pari passu a pacificação interna e estabilização da autoridade no ambiente interno.

A cidadania é outra variável importante na formação do Estado. Enquanto para Tilly (1996) os direitos de cidadania surgiram em grande parte devido às necessidades do Estado em angariar capital e meios de coerção da 
população para empreender as guerras, Giddens (2001) enxerga os direitos civis (direito de organização, por exemplo), políticos (direitos de representação política e elegibilidade) e sociais (direito à saúde e educação, entre outros) ${ }^{19}$ como uma faca de dois gumes: ao mesmo tempo em que são aspectos de vigilância e pacificação, visto que podem ser mobilizados para expandir o controle da classe dominante e manter os demais em posições subordinadas, oferecem aos subalternos possibilidades para ao menos conter o controle sobre eles exercido. Ainda que apresentem visões distintas, ambos notam que este processo aumentou o tamanho e a forma dos Estados modernos.

Estes desenvolvimentos possibilitam na análise de Giddens a distinção entre os Estados tradicionais e os Estados modernos. Conforme as caracterizações arroladas pelo autor, vemos que os Estados tradicionais seriam aqueles que possuem limites, alcançam sucesso limitado na monopolização do uso da violência legítima, o conflito de classe não é a variável estruturante da vida social, não existe uma esfera autônoma da economia e a taxação é a maior ligação entre o Estado e a população. Por outro lado, nos Estados modernos, os governantes conseguem com mais sucesso monopolizar o uso da violência legítima, o conflito de classes é o veículo para a organização política, há uma separação entre a política e a economia, e o Estado abrange outros âmbitos da vida da população além da taxação. Ademais, os desenvolvimentos administrativos e aqueles relacionados com o desenvolvimento capitalista levam à criação de um oficialato vocacional, diferentemente do Estado patrimonial de outrora, caracterizado pela nomeação de membros da aristocracia.

Além disso, devemos ter em mente que o processo de criação dos Estados não foi algo linear em que outras formas de dominação política evoluíram até tal patamar; muitas vezes o Estado competiu com outras entidades e, por se mostrar extremamente eficiente nas artes da guerra, foi emulado por terceiros. Mesmo o caso da Europa não foi uniforme. Conforme aponta Anderson (2004), foi a pressão do absolutismo ocidental que forçou a

\footnotetext{
${ }^{19}$ Tal divisão é proposta por Marshall (1967) e utilizada por Giddens em seu livro, apesar de o autor preferir cambiar direitos sociais para direitos econômicos.
} 
adoção ulterior, por parte da nobreza do Leste, de uma máquina centralizada para poder sobreviver ${ }^{20}$.

Assim sendo, concordamos com Giddens (2001) cujo raciocínio aponta para o fato de que o sistema de Estados europeu não foi simplesmente o ambiente político no qual o Estado se desenvolveu. De acordo com o autor (2001: 137), foi a condição e, em um grau significativo, a fonte real desse desenvolvimento. Ainda conforme Giddens (2001), os Estados só existem em relações sistêmicas com outros Estados pois a coordenação administrativa interna de um depende de condições monitoradas reflexivamente de natureza internacional.

Outrossim, temos três processos que caracterizam os últimos quinhentos anos (TILLY, 1996). Primeiramente, houve a consolidação em quase todo o continente europeu do Estado enquanto forma de organização política, com fronteiras bem-definidas e relações mútuas. Em segundo lugar, o sistema europeu se disseminou por todo o mundo e, em terceiro lugar, os Estados europeus, agindo conjuntamente e/ou em concorrência, influenciaram a criação e organização de novos Estados nos demais continentes, por intermédio da colonização e/ou da conquista.

Nas linhas acima, procuramos sintetizar os processos que culminaram na construção do Estado e estabelecer as bases teóricas necessárias para compreendermos nosso estudo de caso. A partir de agora, é imperativo que salientemos como o tal entidade expandiu-se alhures e como sua atuação afetou a criação dos novos Estados incorporados ao sistema europeu.

\footnotetext{
${ }^{20}$ Anderson (2004), devido ao seu viés marxista, argumenta que o Estado absolutista no Ocidente foi o aparelho político de uma classe feudal para compensar as perdas oriundas do desaparecimento da servidão no contexto de uma economia cada vez mais urbana que não era passível de ser controlada pelos meios anteriores. Na Europa Oriental, por sua vez, o Estado foi um mecanismo para a consolidação da servidão num ambiente no qual não existiam cidades autônomas ou resistência urbana. Apesar de se distanciar das abordagens utilizadas até o momento, compartilha da idéia de que a competição entre as unidades foi uma das variáveis que possibilitou a expansão do Estado por todo o Velho Continente.
} 


\subsection{PARA ALÉM DA EUROPA}

Antes de mais nada, é importante salientar que outras formas de organização política existiram fora da Europa e conseguiam controlar de maneira eficiente seus territórios. O Império Romano, o Império TurcoOtamano e as dinastias encontradas na China são apenas alguns exemplos de organizações que conseguiram firmar-se enquanto centros de autoridade (TILLY, 1996; GIDDENS, 2001, WATSON, 2004, ABERNETHY, 2000). Com esta nota queremos deixar claro que os demais continentes não eram desertos ou mesmo amontoados de povos vivendo no caos.

Concomitantemente ao processo de formação dos Estados europeus, encontramos importantes eventos que impulsionaram a migração desta entidade para os demais quadrantes do globo. A paixão religiosa e a idéia do fardo do Homem Branco, além do gosto pela aventura, seriam alguns dos motivadores que impeliram os europeus a deixarem seu continente e colonizarem o mundo. Todavia, devemos ter em mente que, paralelamente, a conjuntura européia passara por mudanças profundas: as guerras do continente impediram a continuidade das rotas comercias pela terra e moveram-nas para o mar; e a emergência dos Estados, com suas fronteiras mais rígidas e suas vantagens na guerra sobre as demais formas de organização política, fizeram com que a conquista de novas posses territoriais dentro do continente se restringissem ainda mais. Associado a tal quadro, não podemos deixar de destacar o boom demográfico ocorrido nos séculos $X V$ e $\mathrm{XVI}$ e que culminara na necessidade de novos territórios pari passu aos desenvolvimentos científicos e tecnológicos do período renascentista, que permitiram o desenvolvimento de uma indústria ultramarina no início do século $X V I^{21}$. Conforme sublinha Watson (2004: 373):

"Essa importante expansão do sistema europeu, que o levou a cobrir o mundo inteiro, foi um resultado dos avanços repentinos e cinéticos operados na tecnologia, às vezes chamados de Revolução Industrial, que em muito aumentaram o poder econômico e estratégico dos

21 Além de ser uma história riquíssima, não é do escopo desta seção abordar pormenorizadamente todos os fatores que propiciaram o desenvolvimento do colonialismo europeu. Para maiores detalhes, sugere-se Ferro (1996). 
europeus com relação a comunidades não européias. Na Europa, o poder dos Estados cresceu à medida que a Revolução Industrial se disseminou e que as pressões dentro do sistema aumentaram. $O$ poder necessário para expandir-se na Europa produzia benefícios crescentes se fosse dirigido para fora, para lugares onde a expansão encontrasse menos resistência".

Assim sendo, a partir do século $\mathrm{XVI}$, os modernos Estados europeus iniciaram a construção de verdadeiros impérios ultramarinos. Pioneiros, Portugal e Espanha foram seguidos pela Holanda no século XVII e por Inglaterra e França nos séculos XVII e adiante. De acordo com Buzan e Little (2000:257), em 1500 os europeus controlavam 7\% das terras do mundo. Em 1800 controlavam 35\%. Em 1914 haviam estendido seus domínios para os três continentes (América do Norte e do Sul e a Austrália) e controlavam 84\% dos territórios mundiais.

Essa expansão européia a partir do século XVI é o evento que, segundo Wallerstein (1976), inicia a formação do sistema capitalista mundial, ou, a Economia-Mundo que perdura até os nossos dias. Segundo o autor, é pouco produtivo aplicar divisões tais como Primeiro, Segundo ou Terceiro Mundo visto que há uma unidade no sistema capitalista mundial: de um lado temos os países do centro, caracterizados por seu progresso tecnológico; e as áreas periféricas, as quais fornecem matérias-primas, produtos agrícolas e força de trabalho para os investimentos de capital. Logo, notamos que o intercâmbio entre os dois pólos é desigual, porquanto a periferia vende seus produtos mais baratos enquanto compra as mercadorias produzidas no centro por preços mais caros, ocorrendo o que Furtado (2007) chamou de deterioração dos termos de troca. Ademais, temos também a presença de áreas semiperiféricas, regiões de desenvolvimento intermediário que possuem uma função importante: impedem que as pressões oriundas da periferia atinjam os países do centro (WALLERSTEIN, 1976). Assim, a história do sistema capitalista mundial confunde-se com a expansão dos povos e Estados europeus por todo o globo, seja pela conquista militar, seja pela exploração econômica.

As diferenças qualitativas entre os diversos componentes da Economia-Mundo em termos econômicos, culturais, sociais e políticos seriam 
uma conseqüência do próprio caráter do sistema, que tende a perpetuar a desigualdade entre centro, semiperiferia e periferia. Destarte, tendo-se em mente esta interação calcada na desigualdade entre os Estados, diferentes estruturas estatais surgiram ao redor do planeta, umas mais fortes que as outras. Um Estado forte, conforme o pensamento de Wallerstein, seria aquele com capacidade superior vis-à-vis outros Estados e que, consequentemente, teria mais margem de manobra dentro desta Economia-Mundo. Um Estado fraco, por sua vez, se caracterizaria por ser subalterno aos ditames do centro e, portanto, sem oportunidade para desenvolver um aparato estatal capaz de liderar um complexo industrial-econômico-agricultural (WALLERSTEIN, 1976: 232).

Este processo já salienta diferenças substanciais entre a formação do Estado na Europa e nos demais territórios pelos quais fincou raízes. Se, conforme Tilly (1996), raramente os governantes europeus tinha consciência de que modelo de Estado queriam e os principais órgãos desta entidade (fossem eles o tesouro, os tribunais ou as administrações centrais) foram construídos mais como epifenômenos dos esforços para cumprir tarefas mais imediatas, especialmente a criação e manutenção das forças armadas, no caso colonial, os futuros Estados tinham uma função específica: faziam parte da cadeia produtiva européia, seja no fornecimento de produtos primários, seja como mercados para os produtos manufaturados europeus. ${ }^{22}$

Assim sendo, conforme salienta Rubin (2005), os Estados europeus tentaram assegurar seus interesses integrando a periferia do sistema por meio de mecanismos como a conquista, impondo domínios coloniais diretos ou indiretos, apoiando Estados-tampões subordinados, ocupando territórios com imigrantes europeus e debelando rebeliões nativas. Ademais, tentaram regular sua competição por meio de acordos e mecanismos jurídicos, tais como a Conferência de Berlim (15/11/1884 a 26/02/1885), cuja ambição principal era delimitar o colonialismo europeu no continente africano. Por fim, cabe salientar que alguns países escaparam da colonização européia mas foram influenciados pelos países europeus e muitos deles cambiaram suas

\footnotetext{
${ }^{22}$ É interessante notar que das 10 primeiras entradas do Índice de Estados Falidos de 2007, somente dois países (Iraque, 2ํㅣ lugar; e Afeganistão, $8^{\circ}$ lugar) não fazem parte do continente africano, considerado a periferia do sistema capitalista.
} 
estruturas internas para poderem sobreviver frente aos novos adversários sistêmicos (BUZAN E LITTLE, 2000).

As experiências históricas singulares permitiram a distinção por parte de diversos autores de vias distintas de formação do Estado. Giddens (2001) argumenta que, ainda que o Estado europeu tenha fornecido o padrão a ser emulado, é evidente que não seria possível uma cópia integral da experiência européia e, muitas vezes, os países que se formaram em outros continentes apresentaram trajetórias distintas, principalmente em processos de rebelião frente à dominação européia. Dessa forma, autores como Anthony D. Smith (1992: 349) apresentam 4 tipos de formação do Estado, quais sejam:

a)

Ocidental: Estado e nação emergem pari passu, pois o Estado dinástico e territorial se construiu em torno de um núcleo étnico definitivo;

b) Imigrante: uma pequena etnia, com ou sem luta, tornou-se beneficiária de um Estado a ela vinculado, passando a tentar absorver e assimilar levas de novos imigrantes;

c) Étnico: antes do advento do Estado moderno e racional já existiam etnias com graus variáveis de integridade e autoconsciência, que então passam a reivindicar sua elevação e transformação ao status de nações plenas, dotadas de territórios, economias entre outros atributos;

d) Colonial: onde um Estado é imposto de cima para baixo a populações divididas.

Por conseguinte, vemos que, a despeito das formas distintas, 0 Estado foi-se espalhando pelo globo. Muitos países apresentaram experiências interessantes para enfrentar o desafio colocado pelo avanço europeu. Por outro lado, para que o processo de expansão do Estado pelo globo fosse ainda mais acelerado, outras variáveis entraram na equação além dos esforços dos dirigentes. Segundo Creveld (2004: 371): 
"Inicialmente o Estado foi idealizado como mero instrumento para impor a lei e a ordem: um órgão composto de instituições, leis e pessoas que serviam a essas instituições e impunham o cumprimento dessas leis, funcionando como uma máquina ao realizar suas tarefas. Todavia, quase exatamente no meio de sua evolução, entre 1648 e 1945, deparou-se com as forças do nacionalismo que, até então, tinham se desenvolvido quase independentemente dele e, às vezes, contra ele. O Estado dos séculos XVII e XVIII não exigia afeto especial da parte dos súditos, contando apenas que obedecessem a seus decretos e suas exigências de dinheiro e mão-de-obra; mas agora poderia recorrer ao nacionalismo para preencher seu vazio com um teor ético".

Desta afirmação, devemos sublinhar a importância que o nacionalismo ${ }^{23}$ teve na formatação dos novos Estados. Segundo o mesmo autor, inicialmente o Estado fora concebido enquanto um meio para amainar os conflitos civis e religiosos europeus além de garantir a vida e a propriedade por meio da imposição da lei e da ordem. Não obstante, após os efeitos vislumbrados durante a Revolução Francesa (1789-1799), aonde a causa nacionalista foi utilizada para angariar apoio da população e por fim ao Antigo Regime, os governantes viram a capacidade que o nacionalismo enquanto ideologia podia ter para vincular ainda mais a população ao governo e ao menos camuflar as divisões de classes. Tal fenômeno transformou os súditos em cidadãos: se os primeiros tinham apenas que obedecer aos ditames do Estado e este não exigia mais do que a obediência incondicional, a partir de agora os segundos também tinha direitos. Todavia, tais direitos levavam a uma gama maior de deveres com relação ao seu país, dentre os quais matar e morrer pela pátria.

Se, conforme concebido por Rousseau e Herder (apud Creveld, 2004), o nacionalismo era uma preferência inofensiva pelo país natal, por sua língua e costumes, ao ser adotado pelo Estado, tornou-se agressivo e belicoso. A partir de agora, todas as nações tinha direito a ter seu próprio Estado. Princípios como os de autodeterminação dos povos começaram a ser utilizados

${ }^{23}$ Comungamos da definição de Gellner (apud Hobsbawn, 1990: 18) o qual afirma que nacionalismo significa fundamentalmente um princípio que sustenta que as unidades políticas e nacionais devem ser congruentes. Para maiores detalhes sobre Nação e Nacionalismo, Hobsbawn (1990). 
para legitimar as guerras que os Estados passariam a promover. Dessa forma, reforçar-se-ia ainda mais a dicotomia entre o interno e o externo na política internacional.

As mudanças sistêmicas ocorridas principalmente após a Segunda Guerra Mundial também foram muito importantes no processo de consolidação dos Estados nacionais. A falência dos impérios coloniais europeus, a ascensão de duas novas superpotências fora do eixo Berlim-ParisLondres e a criação da Organização das Nações Unidas produziram impactos substanciais no ordenamento internacional (JACKSON, 1990). Um deles, senão o principal foi a ascensão de um novo regime de soberania. Este novo regime de soberania permitiria caracterizar os países do Terceiro Mundo:

“(...) não como estruturas que se auto-sustentam por meio de alicerces domésticos - como se fosse prédios separados - e sim como jurisdições apoiadas pelo direito internacional e ajuda externa - uma espécie de rede de auxílio internacional. Em síntese, eles aparentam ser mais entidades jurídicas do que empíricas, portanto, Quase-Estados (1990:05)".

Segundo o autor, o novo sistema internacional que se erigia tinha como uma de suas características fundadoras a idéia de que todos os povos, a despeito de suas culturas, raças, riquezas e/ou geografias, tinham direito à independência. Os antigos Estados coloniais, devastados pelos efeitos da Segunda Guerra Mundial, não tinham mais condições de sustentar a legitimidade do domínio colonial e, um a um, foram cedendo. Levando o argumento ao limite, Jackson sustenta que para ser um Estado soberano, era necessário apenas que o país tivesse sido uma ex-colônia. Esta nova conjuntura possibilitou a origem dos Quase-Estados (Quasi-States), caracterizados primordialmente por serem entidades jurídicas, mas sem possuírem soberania de fato, o que gerou a convivência de dois regimes de soberania distintos. De um lado temos o regime tradicional (cunhado por Jackson como soberania positiva) que pressupõe:

"Capacidades que permitem aos seus governos serem seus próprios mestres: é uma condição substantiva ao invés de formal. Um 
governante positivamente soberano é aquele que não apenas goza do direito de não-intervenção e de outras imunidades internacionais, mas também possui os recursos para prover bens políticos para seus cidadãos (JACKSON, 1990: 29)".

De outro lado, temos a ascensão da soberania negativa caracterizada enquanto:

"Liberdade frente à interferência externa: uma condição formal-legal. A não-intervenção e a soberania, nesse sentido, são basicamente dois lados da mesma moeda. (...) É um atributo formal-legal e, consequentemente, algo que a sociedade internacional é capaz de $\operatorname{dar}(J A C K S O N, 1990: 27)$.

Ottaway (2002), tendo em mente a argumentação proposta por Jackson e o contexto pós Segunda Guerra Mundial, conceitua três tipos de Estado. Os Estados de jure são aqueles que existem devido ao reconhecimento da comunidade internacional a despeito de sua falta de capacidade para controlar e governar determinado território ${ }^{24}$. Os Estados de facto são divididos em duas categorias: aqueles que controlam e governam determinado território e possuem reconhecimento internacional; e aqueles que controlam e governam uma porção territorial mas não possuem reconhecimento de outros países e dos organismos internacionais ${ }^{25}$.

A ascensão e concomitante expansão do Estado, enquanto forma dominante de organização política formatou todo o sistema internacional contemporâneo. A partir de agora, todos os Estados são soberanos e possuem seus territórios estritamente demarcados. As atuais fronteiras, incluindo àquelas outorgadas às ex-colônias, são legitimas e legais; qualquer tentativa de se mudar tal configuração vai contra o princípio organizador das relações internacionais: a soberania nacional.

Esse contexto é significativamente diverso daquele no qual 0 Estado europeu emergiu. A preparação para a guerra na Europa do século XVI

\footnotetext{
${ }^{24}$ O melhor exemplo, segundo a autora, é o caso da Somália que também segundo Rotberg (2004), é o único Estado em colapso existente.

${ }^{25}$ Segundo a autora, a Somaliland, uma porção territorial que busca a independência da Somália, se encaixa nessa definição.
} 
era extremamente importante visto que qualquer fracasso nesta empreitada poderia culminar na subjugação ou mesmo incorporação do Estado derrotado: no limite, ele poderia deixar de existir. Contemporaneamente, conforme argumenta Sorensen (2001), os Estados possuem um seguro de vida garantido pelas Nações Unidas, cuja principal conseqüência é a manutenção de seu território e de sua soberania não importando o quão ruim esteja a situação no âmbito doméstico. As ex-colônias estariam assim protegidas de qualquer ameaça externa à sua sobrevivência por normas internacionais.

$\mathrm{Na}$ Europa estudada por Tilly e que foi o ponto de partida para a formação da Economia-Mundo proposta por Wallerstein, os governantes enfrentaram e negociaram com a sua população para extraírem os recursos necessários para se defenderem e empreenderem guerras contra inimigos externos. No mundo pós-colonial os governantes enfrentaram e negociaram principalmente com as potências externas ${ }^{26}$ para obterem ajuda e capital para se protegerem das ameaças internas à sua dominação. Com o final da Guerra Fria, grande parte do auxílio externo deixou de entrar nos cofres desses países e, sem fontes internas de receitas, os governantes buscaram novas rendas na população (RUBIN, 2005). Se a principal preocupação na Europa do século XVI era com a ameaça externa, os países do dito Terceiro Mundo tinham que lidar com as ameaças internas à sua dominação. Afiançados por esta conjuntura, muitos governantes dos novos países apoiados pelas potências externas, principalmente no período da Guerra Fria, puderam atuar conforme seu bel-prazer. A demarcação do território, uma das etapas mais difíceis da construção estatal na Europa, já estava garantida.

Os governantes do Terceiro Mundo que empreenderam construções estatais encontraram uma economia global estabelecida e um sistema diplomático e legal que ditava certas características de uniformidade para o comportamento estatal às quais os novos países não podiam escapar. O Estado tornou-se, conforme aponta Rubin (2002), autônomo frente à sociedade: armas podiam ser importadas ao invés de serem produzidas internamente; e as receitas advinham de países e/ou organizações

\footnotetext{
${ }^{26}$ Deve-se lembrar que estamos no período da Guerra Fria, na qual EUA e URSS disputavam áreas de influência e, por isso, providenciaram ajuda a muitos países que saíram da descolonização. Ademais, o fim das colônias redundaria no término da influência européia no sistema internacional, assegurando a consolidação dos espaços de cada bloco.
} 
internacionais, sem acumulação de capital nacional. Enfim, as barganhas que caracterizaram o Estado na Europa não tiveram o mesmo peso em tal conjuntura.

O Estado autônomo pôde tanto procurar estruturar a sociedade para atingir metas redistributivas e desenvolvimentistas ou, em outro extremo, apresentar um caráter predatório, atacando a sua população sem temor de ser derrubado ${ }^{27}$. Assim, o Estado, ao invés de se tornar o centro coordenador da sociedade, restringe-se a apenas mais uma instituição dentro do território, engajada em uma luta constante para o controle social. Não obstante, apresenta uma grande vantagem frente às demais instituições: é reconhecido internacionalmente.

Em resumo, os processos e variáveis que salientamos deixam claro que não se pode compreender os Estados sem compreender também suas conjunturas de origem. Se os ditos Estados Falidos podem ser adjetivados enquanto tais, devemos ter em mente não apenas suas características internas, como também o processo mais amplo de consolidação da forma Estado nas relações internacionais. Contudo, se é verdade que a explicação proposta por Jackson (1990) é de grande valia para compreendermos, por exemplo, situações como a fraqueza estatal na África, quando nos deparamos com um caso como o do Afeganistão, país que não passou pelo processo de descolonização das décadas de 1950 e 1960, os conceitos propostos pelo autor não ajudam muito. Para isso, precisamos entender como a instituição Estado foi levada para este recanto da Ásia Central. Concordamos com Rubin (2002) e Saikal (2004): para entendermos o Afeganistão temos de ter em mente sua interação com o sistema internacional. É por isso que a partir de agora nos voltaremos para a história deste país, procurando destacar como suas relações sistêmicas, conjugadas com variáveis internas, possibilitaram a ascensão do que hoje analistas chamam de um Estado Falido.

\footnotetext{
${ }^{27}$ Um exemplo de Estado predatório é o ex- Zaire (atual República Democrática do Congo) analisado por Evans (1993). Segundo o autor, encontramos um Estado predatório que é autônomo perante a população, uma vez que suas metas estão associadas ao enriquecimento da elite no poder, deixando de proporcionar os pré-requisitos básicos para o bem-estar social e para o funcionamento de uma economia moderna (investimentos públicos em saúde e educação, infra-estrutura, entre outros).
} 
Mapa político do Afeganistão 28

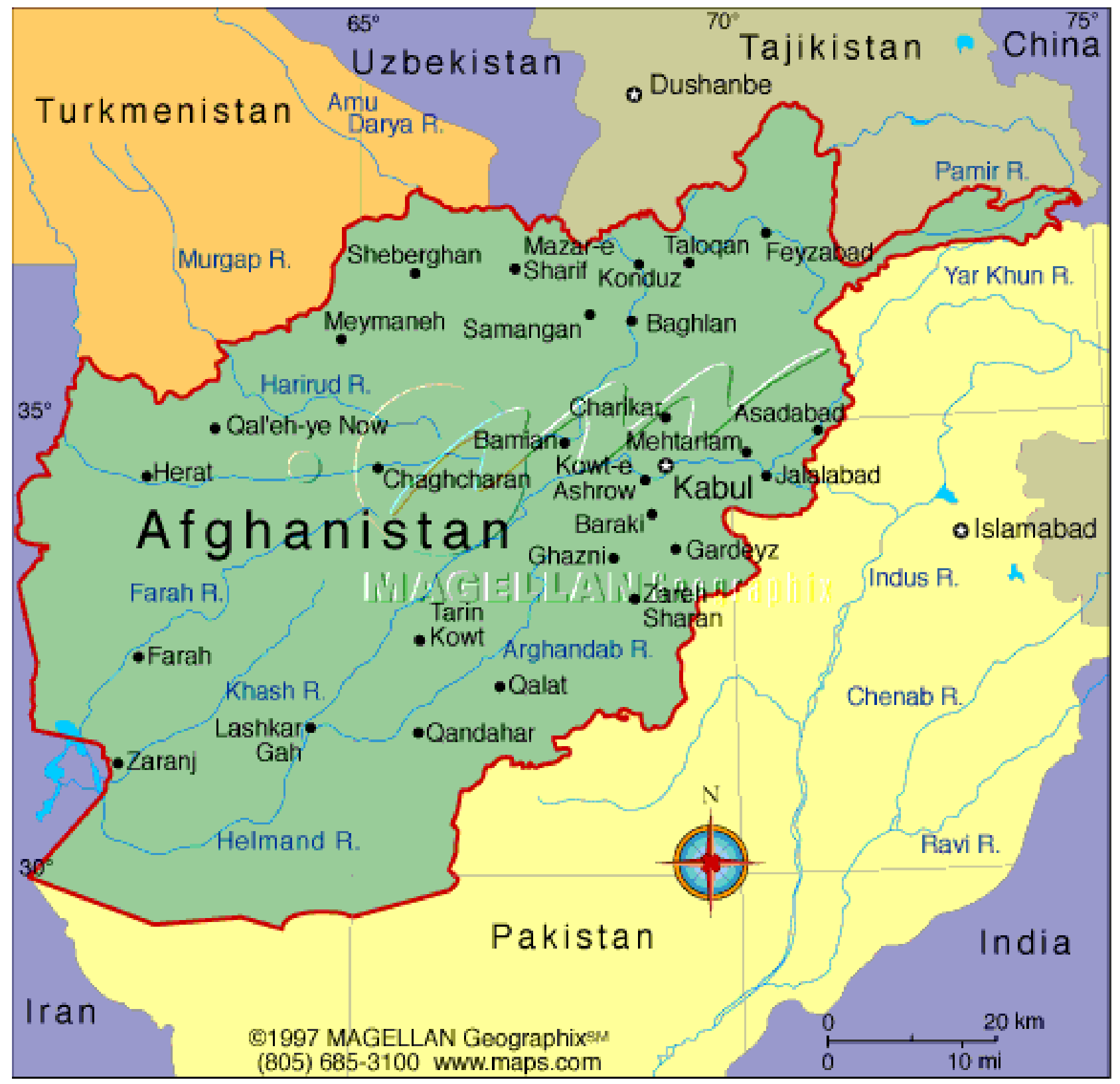

28 Disponível em http://media.maps.com/magellan/Images/AFGHAN-W1.gif. Acesso em 12/05/2008. 


\section{O AFEGANISTÃO}

"Quando Alá terminou a construção do mundo, Ele notou que havia sobrado muito lixo e diversas outras coisas que não se encaixavam em lugar algum. Ele as reuniu e as jogou em determinado ponto na terra. Aquilo tudo se tornou o Afeganistão ${ }^{29}$."

\subsection{NOTAS PRELIMINARES}

Nas seções anteriores procuramos salientar como a construção estatal é uma variável extremamente importante para a compreensão dos ditos Estados Falidos. A partir de agora, por meio do caso do Afeganistão, procuraremos mostrar a importância de uma análise conjugada de variáveis sistêmicas com fatores internos na formatação desse processo.

Procurando identificar as possíveis causas para a falência estatal, Ignatieff (2002) arrola fatores como o legado colonial, a má administração por parte das elites domésticas, as interferências externas e os custos que a globalização econômica podem trazer para os países. Quando nos deparamos com esta lista, vemos que as explicações para o fracasso estão localizadas em diversos níveis de análise ${ }^{30}$ : ora os responsáveis são as lideranças internas, ora as instituições estatais, ora o sistema internacional. Comungamos da opinião de Einsiedel (2005: 17): tais explicações não devem ser vistas como excludentes e sim como complementares porquanto iluminam aspectos importantes da construção de Estados não-Europeus. Sobre o Afeganistão, encontramos modelos explicativos que ora salientam o relacionamento entre um Estado débil e uma sociedade forte (SAIKAL, 2004), ora privilegiam explicações de cunho sistêmico (RUBIN, 1988; RUBIN, 2002), demonstrando como o encontro do Afeganistão com o sistema internacional de Estados influenciou o destino do país. Conquanto cada modelo apresente um recorte importante, acreditamos que tais abordagens são complementares e que conjuntamente problematizam melhor as questões relativas ao fracasso estatal. Se o foco da literatura sobre os Estados Falidos salienta a dificuldade dos países em emular o modelo europeu, devemos entender porque as instituições

\footnotetext{
${ }^{29}$ Apud RASHID, 2001: 07

${ }^{30}$ Sobre Níveis de Análise, o trabalho seminal é Waltz (2004).
} 
no Terceiro Mundo não conseguiram lograr este objetivo. Por meio da história do Afeganistão, ainda que particularidades históricas perpassem a construção estatal do país, acreditamos poder contribuir para a compreensão deste fenômeno.

\subsection{O ESTADO NO AFEGANISTÃO}

Localizado no coração da Ásia Central, atualmente fazendo fronteira com a China, Irã e Paquistão, o espaço ocupado pelo atual Afeganistão vivenciou muito mais do que o domínio dos Talibã e a presença da Al Qaeda de Osama Bin Laden em seu território. A história do país apresenta contornos mais amplos, perpassada por invasões sucessivas, conflitos internos entre etnias rivais e entre membros dos governos que durante os anos foramse alternando no poder. Pelas estepes e desertos do território afegão passaram personagens históricos e eventos importantes: Alexandre, o Grande dominou a região em 331, após uma série de conflitos com os persas, e o Islã, principal crença religiosa do país, atingiu a região durante os anos de 637 e 642, quando árabes muçulmanos capturaram Herat e Balkh, duas das mais importantes cidades do que viria ser o Afeganistão ${ }^{31}$.

Anterior a qualquer esboço de um Estado afegão, o território fora dominado por impérios distintos: os Mongóis, comandados por Gengis Khan, tomaram a região em 1221 e após sua morte, em 1227, seus descendentes controlaram o futuro Afeganistão. Não obstante, o advento dos Impérios Safávida, na Pérsia, e do Império Mogol, na Índia, culminou na eclosão de disputas pela hegemonia na região, as quais perduraram até os séculos XVI e XVII. Tais impérios em nenhum momento objetivaram exercer grande dominação sobre a população: as diversas etnias presentes no território organizavam-se em contornos tribais e cada qual possuía um líder. Diversas tribos convivendo em um ambiente em que nenhuma delas havia alcançado

\footnotetext{
${ }^{31}$ A consolidação do Islã foi um processo deveras difícil, uma vez que outras crenças como o Zoroastrismo e o Budismo haviam passado pela região. As estatuas dos Budas em Bamiyan são o melhor exemplo de como tais religiões deixaram suas marcas. Os muçulmanos que se aventuraram pela Ásia Central, em especial no Afeganistão, enfrentaram um sem-número de levantes nos vilarejos, principalmente naqueles em que crenças politeístas ainda prevaleciam. Foi somente após o século IX, quando a expansão muçulmana alcançou Cabul, que o Islã dominou a maior parte do território do país. Para maiores detalhes, EWANS (2002).
} 
preponderância sobre as demais nos remete à competição pela monopolização proposta por Elias (1993) e apresentada anteriormente. Todavia, a diferença no caso afegão é que as tribos, além de enfrentarem umas as outras, tinham que lidar com os impérios que passavam pela região, o que impedia a vitória de qualquer uma delas. Tal quadro, conforme salienta Saikal (2004: 17), resultava em uma conjuntura em que:

"Novas organizações políticas emergiam das ruínas dos impérios que entravam em colapso, alcançavam determinado tamanho (por vezes, pouco maior do que os limites de uma família) e se fragmentavam, ora devido às disputas acerca da sucessão, ora por pressões externas ou escassez de recursos, resultando em organizações menores que novamente, como num ciclo, cresciam para depois perecerem. Até o meio do século XVIII, o Afeganistão era essencialmente uma frouxa confederação de chefes tribais convivendo na periferia dos moribundos impérios Safávida, na Pérsia e Mogol, na Índia."

A configuração política começa a mudar a partir de 1747, com a formação da Monarquia Durrani. Ahmad Shah Abdali, líder da tribo Pashtun Durrani $^{32}$, era uma figura proeminente dentro do Império Persa, o qual controlava cidades importantes do futuro Afeganistão. Com a morte do rei persa Nadir Shah Afshar, Ahmad Shah dirigiu-se a Kandahar e se reuniu com outros líderes tribais, logrando criar uma grande aliança a qual resultou na criação de uma Confederação Afegã. Ainda que sua autoridade não fosse inicialmente reconhecida por todos os chefes tribais presentes no território e que Ahmad Shah tivesse que se valer da conquista e diplomacia para expandir a confederação, Saikal (2004) salienta que este momento foi importante na história do Afeganistão uma vez que uma liderança conseguiu alcançar o título de monarca do Afeganistão ${ }^{33}$. Durante os 25 anos de seu reinado, sua principal missão foi libertar as tribos que ainda se encontravam sob domínio persa e

\footnotetext{
${ }^{32}$ A grafia dos nomes e etnias varia conforme o autor. Para mantermos um padrão único, optamos por seguir Saikal (2004).

${ }^{33} \mathrm{O}$ título exato de Ahmad Shah foi Durr-e Durran (Pérola das Pérolas), o que corresponderia ao cargo de rei nas monarquias européias.
} 
mogol, incluí-los numa macro-socieadade maior e consolidar seu domínio, distinguindo seus domínios dos demais presentes na região.

De acordo com Rubin (2002), uma das metas ansiadas pela confederação formada por Ahmad Shah, majoritariamente Pashtun, consistia em conquistar terras até então dominadas por outras etnias. Uma vez alcançados os objetivos, a próxima tarefa era a manutenção de tais conquistas: em nenhum momento o Estado em formação se preocupou em governar a população ali residente, tarefa que demandaria muito mais do que a incipiente confederação poderia oferecer. Destarte, ao mesmo tempo em que a maior parte dos chefes tribais reconhecia a autoridade de Ahmad Shah, visto que todos ambicionavam o fim dos domínios persa e mogol na região, este último deixava que as lideranças locais organizassem a seu bel-prazer a população dentro do território afegão, embora exigisse cooperação via a manutenção de um exército para a expansão das conquistas da confederação ${ }^{34}$. Contudo, esta dinâmica entre uma Confederação em construção e diversas tribos e etnias com mecanismos institucionalizados de dominação criava empecilhos para o fortalecimento de um Estado Afegão na região.

Procurando caracterizar o governo de Ahmad Shah e tendo-se em mente a clássica diferenciação proposta por Weber ${ }^{35}$, podemos adjetivá-lo como carismático, não havendo nenhum aparato administrativo institucionalizado, tampouco qualquer aparato de tributação semelhante aos sistemas governamentais contemporâneos com o objetivo de manter 0 funcionamento do Estado. Um exército multi-étnico conjugado às idéias de direito divino de governar além da forte personalidade do próprio Ahmad Shah constituíam a base da dominação. Dessa forma, o incipiente Estado que emergira após a queda do Império persa dependia basicamente de mecanismos ad hoc, criados pelo líder carismático, do que de estruturas

\footnotetext{
${ }^{34}$ De certa forma, este tipo de relacionamento nos remete à concepção de Tilly de construção estatal em regiões nas quais a concentração de elementos de coerção era preponderante. Isto de fato aconteceu neste período visto que Ahmad Shah dependia dos demais chefes tribais para a manutenção da confederação que almejava implantar na região.

${ }_{35}$ Segundo Weber (2004) existiriam três modelos de legitimação da dominação: (1) a tradicional, que advém do passado eterno, ou seja, os costumes santificados pela validez imemorial e pelo hábito, enraizado pelos homens; (2) o carismático, calcado nos dons pessoais e extraordinários de um indivíduo; e (3) o racional-legal, alicerçado na crença da validez de um estatuto legal e de uma competência positiva, estruturada em regras racionalmente estabelecidas.
} 
institucionalizadas que permitissem a auto-reprodução estatal. Por conseguinte, muitas lideranças tribais constantemente questionavam a liderança de Ahmad Shah, culminando em diversas disputas pelo trono além de mais um agravante: a Confederação não tinha uma receita fixa, dependendo principalmente das conquistas territoriais e dos demais chefes tribais.

Para piorar ainda mais o já complicado contexto, Saikal (2004) destaca o papel da poligamia dentro da família real, cujas conseqüências dificultavam ainda mais uma sucessão pacífica. Segundo o autor, o Corão, livro sagrado dos muçulmanos, autoriza que o homem tenha até quatro mulheres desde que possa tratá-las de maneira equânime, além de um número nãoespecificado de mulheres que tivessem sido deixadas desprotegidas, principalmente após a morte de seus familiares e maridos ${ }^{36}$. Numa sociedade patriarcal $^{37}$ como a do Afeganistão, tais práticas tornaram-se usuais e grande parte dos homens possuía mais de uma mulher. A família real não era exceção, o que culminou numa proliferação de herdeiros e, consequentemente, sucessores ao trono. Segundo Saikal (2004: 24), a única coisa que diferenciava os herdeiros, fossem eles das concubinas ou das esposas oficiais, era o fato de que se um deles fosse o favorito ou filho da esposa preferida, tinha precedência para a sucessão.

Dessa forma, a morte de Ahmad Shah trouxe uma conseqüência deveras nefasta: não havia mecanismos institucionalizados (e que contassem com o apoio da maioria das partes interessadas) que pudessem garantir a continuidade do governo e, portanto, lutas pela sucessão do trono eclodiram. Procurando caracterizar o reinado de Ahmad Shah, Ewans (2002: 36) salienta que:

\footnotetext{
${ }^{36}$ Por estas e outras práticas o Islã é visto como uma religião misógina, na qual as mulheres têm um papel reduzido. Todavia, devemos ter em mente que o surgimento e concomitante expansão do Islã ocorreu num meio conflituoso e que a divisão sexual do trabalho colocava os homens na guerra e as mulheres enquanto mantenedoras do lar. Por isso, devido às diversas baixas que Maomé teve, o Corão autoriza a poliginia, uma vez que após a morte da família e/ou do marido, as mulheres muitas vezes ficavam desprotegidas. Para maiores detalhes sobre o Islã, Armstrong (2001; 2002).

${ }^{37}$ No Afeganistão, as famílias giravam em torno do patriarca, o qual tem como principal dever protegê-la. O casamento é uma das formas de se fazer alianças políticas entre as tribos, aumentando a importância da poliginia. As mulheres são vistas como repositórios da honra do marido e, por isso, o adultério é tão mal-visto no país, podendo comprometer a fama de toda uma família. Para uma análise magistral sobre a sociedade afegã a referência é Dupree (2002).
} 
"O Império de Ahmad Shah nunca esteve totalmente seguro enquanto ele viveu, estava fadado à desintegração após a sua morte e quiçá seja este o motivo pelo qual este monarca não teve o seu lugar merecido na história do Afeganistão. Não obstante, ele foi o fundador da Dinastia Sadozai, a qual governou até 1818 e que, por meio de um outro ramo da mesma dinastia, iria dominar o Afeganistão até 1978. É por isso que os afegãos o chamam de 'Pai da Nação', ainda que sua criação fosse mais uma Confederação tribal do que um Estado-Nação."

$\mathrm{Na}$ linha sucessória, o segundo filho de Ahmad Shah, Timur Shah, assumiu o trono, procurando manter as conquistas que seu pai lograra alcançar. Todavia, ainda que contasse com o apoio de boa parte das tribos que outrora haviam afiançado o reinado de Ahmad Shah, Timur teve que lidar com diversas revoltas e tentativas de golpes ao mesmo tempo em que algumas regiões do território tornaram-se virtualmente independentes. Após sua morte, em 1793, tendo deixado mais de 30 filhos com as esposas oficiais, dos quais cerca de 20 eram homens, e sem nenhum sucessor escolhido previamente, convulsões dentro da família real novamente emergiram. Ademais, devemos agregar a este contexto o fato de que partes do território estavam sendo perdidas e que as fontes de renda do governo, até então provenientes das conquistas efetuadas principalmente no subcontinente indiano, deixaram de entrar nos cofres governamentais, diminuindo sensivelmente a capacidade do Estado em manter suas possessões.

Além das dificuldades intestinas do Estado afegão, o século XIX marcou a chegada das potências européias à região, fato que iria influenciar fortemente os destinos do país. Se Ahmad Shah se aproveitou da decadência tanto dos Impérios Persa e Mogol para ampliar seus domínios no século XVIII, o quadro agora é diferente na medida em que Inglaterra e Rússia, dois dos principais Estados Europeus do período, iriam determinar quais rumos o Afeganistão deveria tomar. Com suas inovações políticas, econômicas e tecnológicas, Inglaterra e Rússia - a primeira avançando pelo subcontinente indiano enquanto a última pelo norte do Afeganistão - enxergavam-se enquanto inimigos na região: os ingleses queriam manter sua colônia na Índia e os russos ansiavam aumentar sua influência em toda a Ásia Central. Dentro das 
ambições geopolíticas das duas potências, o Afeganistão encontrava-se encurralado: qualquer tentativa da Rússia czarista em tomar o território afegão era entendida em Londres como uma ameaça à dominação inglesa. Por outro lado, as tentativas da Inglaterra em fortificar as fronteiras de seu império no subcontinente eram vistas pelos russos como possíveis tentativas inglesas para minar a sua influência na região (EWANS, 2002) ${ }^{38}$. A corrida imperialista entre Inglaterra e Rússia na região entrou para a história como o Grande Jogo e o Afeganistão, era um coadjuvante de peso. Segundo Saikal (2004:26):

\begin{abstract}
"De um lado, a Inglaterra manipulava os afegãos como uma força de resistência frente às possíveis ambições russas vis-à-vis o subcontinente indiano e o Golfo Pérsico. De outro lado, os russos se tornavam cada vez mais assertivos nos seus desejos de aumentarem sua influência nos territórios da Ásia Central que se encontravam entre a Rússia e o Afeganistão".
\end{abstract}

Entrementes, o esboço de Estado ansiado por Ahmad Shah caminhava rumo à desintegração. $O$ país encontrava-se dividido em três grandes regiões - Cabul, Kandahar e Herat - além de pequenas províncias. No período em questão, houve uma sucessão de líderes cuja principal ambição era reunificar o Estado afegão e findar com o domínio paralelo dos demais chefes tribais. Todavia, a presença das duas potências imperialistas, cada qual com seus próprios interesses em questão, diminuía enormemente as escolhas das lideranças afegãs. Na medida em que ficavam cada vez mais claras as intervenções russas tanto na Pérsia quanto no Afeganistão, a Inglaterra notava a necessidade de uma política externa mais austera para a região. Primeiramente, os ingleses retiraram Dost Mohammed do poder e empossaram Shah Shuja, um títere da Inglaterra no Afeganistão, o que deu início à Primeira Guerra Anglo-Afegã (1839-1842). A justificativa inglesa para a invasão baseava-se em indícios de que Dost Mohammed, o qual havia tomado o poder

${ }^{38}$ Conforme Ewans (2002: 50-51), a Inglaterra tornara-se cada vez mais temerosa sobre sua dominação no subcontinente indiano a partir da primeira década do século XIX, quando a França direcionou suas atenções para a Pérsia (atual Irã) tornando cada vez mais tangível uma possibilidade de invasão. No entanto, com o fim das ameaças francesas, o perigo voltou a rondar as possessões inglesas quando os russos, a partir da década de 1830 afirmaram o Tratado de Turkmanchai com a Pérsia, culminando na subserviência persa à Rússia. Acreditase que a Rússia almejava que os persas tomassem porções significativas do Afeganistão, aumentando a influencia russa na região e ameaçando cada vez mais a posição inglesa. 
em Cabul e almejava dominar todo o território afegão, estaria ameaçando as fronteiras do Império inglês na Índia.

Essencial para a união das diversas tribos e etnias afegãs foi a ameaça de dominação externa representada pela Inglaterra. O resultado deste primeiro embate entre afegãos e ingleses, por mais surreal que possa parecer, foi a retirada inglesa do país. Não obstante, devemos ter em mente alguns fatores que foram determinantes para tal acontecimento, a despeito da união dos afegãos frente o inimigo externo. Primeiramente, a Rússia, principal motivo de preocupação para a Inglaterra, havia fracassado em uma expedição ao Khanato de Khiva, em 1840, o que fez com que Londres, ao vislumbrar o ocaso russo, deixasse de temer tanto seu principal adversário e, portanto, diminuísse o peso que dava à questão afegã. Por fim, após as eleições de 1841, mudanças no governo inglês tiraram o suporte que a Guerra Anglo-Afegã outrora tivera. Assim, a retirada das tropas tornara-se a opção mais razoável.

Não obstante, mesmo com a derrota da Inglaterra e o retorno de Dost Mohammed ao trono em Cabul, os russos, que até então não acreditavam em uma possível intervenção inglesa no Afeganistão, passaram a conviver com o fato de que seus adversários estariam dispostos a ampliar seus domínios e romper o tênue equilíbrio entre as potências na região. Tal percepção levou a Rússia a intensificar seus ímpetos hegemônicos em direção ao Afeganistão que, por sua vez, fez com que a Inglaterra uma vez mais buscasse fazer uso de sua Política de Defesa Ofensiva (Forward Defence Policy). O resultado de tais acontecimentos foi a Segunda Guerra Anglo-Afegã (1878-1880), que culminou em uma invasão inglesa. Contudo, desta feita, os afegãos lograram apenas uma vitória parcial uma vez que Abdur Rahman Khan, líder que conseguiu tomar o poder e controlar a maior parte do território do país (18811901), reteve apenas a independência interna do Afeganistão: as relações exteriores do país passaram a ser controladas pela Inglaterra e a Linha Durand, demarcação territorial definida pela Inglaterra, retirou boa parte de terras que outrora haviam sido do Afeganistão e que a posteriori iriam compor o Paquistão.

Uma total subjugação militar ou uma possível colonização foram descartadas tanto pela Inglaterra quanto pela Rússia, porquanto qualquer tentativa nesse sentido colocaria ambas em conflito direto, além de não haver 
recursos econômicos ou minerais que compensassem os custos de uma invasão. O Afeganistão passou então a integrar o sistema internacional como um Estado tampão, diferentemente de outros países que ingressaram como colônias. Segundo Fanzal (2004: 311-312), um Estado tampão seria aquele preso entre dois rivais e que são passíveis de serem conquistados, anexados ou ocupados ${ }^{39}$.

Estas foram as circunstâncias com que Inglaterra, Rússia e Afeganistão passaram a conviver. Para o Afeganistão, integrar-se ao sistema internacional europeu por meio de tal conjuntura significou a tentativa de criação de um Estado no qual a sociedade não tinha papel significativo porque as principais fontes de renda, assim como a definição das fronteiras e do território do país, eram outorgadas aos afegãos por russos e ingleses. Se Tilly (1996) argumenta que na Europa houve trajetórias de construção estatal em que ora prevaleceu o comércio, ora a coerção e, por fim, uma combinação de ambos, no caso do Afeganistão podemos afirmar que o país neste momento passara por um processo coercitivo de construção do Estado financiado pelo sistema internacional. Nem para a Inglaterra e tampouco para a Rússia era interessante um Afeganistão fraco e passível de dissolução pois tais características poderiam incentivar ambos a anexarem o país e ameaçar a presença do outro na região ${ }^{40}$. Dessa forma, após a Segunda Guerra AngloAfegã, a Inglaterra financiou as lideranças internas para que mantivesse o controle de todas as provinciais do país.

Este processo de construção estatal pode ser considerado coercitivo porque os principais financiamentos ingleses para o governo afegão foram direcionados para a criação e treinamento de um exército centralizado, visando diminuir a dependência do Estado dos diversos chefes tribais que até então desempenhavam papel fundamental vis-à-vis os meios coercitivos no

\footnotetext{
${ }^{39}$ O Reino do Sião, atual Tailândia, passou por situação semelhante. Durante os séculos XVII e XIX, conforme Pannikkar (1969), os embates entre os impérios francês e inglês resultaram em uma situação em que a colonização não era interessante pois culminaria em um conflito direto entre as potências em questão. Assim sendo, o Sião pode manter sua independência, ainda que sua integridade territorial dependesse do beneplácito de Londres e Paris.

40 Para formalizar este equilíbrio, a Convenção Anglo-Russa de 1907 afirmava que a Rússia passaria a considerar o Afeganistão fora de sua área de influência e qualquer relacionamento que viesse a ter com o governo de Cabul deveria passar previamente por Londres. Por outro lado, a Inglaterra se comprometia em não ocupar e tampouco anexar porções do território afegão, além de não interferir na soberania interna do país.
} 
país. Abdur Rahman, conforme aponta Rubin (1988), aproveitou-se dos grandes montantes que a Inglaterra injetara no país e procurou dirimir as lideranças tribais por meio de políticas extremamente autoritárias, ora reprimindo diretamente tribos e etnias, ora jogando umas contra as outras. Ademais, todos os assuntos relativos ao Islã passaram a ser controlados pelo Estado além de Rahman afirmar que era o representante de Deus para assuntos temporais e que tinha o direito divino em governar todos os afegãos.

Abdur Rahman procurou expandir os serviços que o Estado poderia oferecer e realizou algumas outras reformas. Ainda que fossem limitadas e sempre objetivassem complementar as capacidades de projeção de poder do Estado, Rahman ampliou a infra-estrutura do país, o comércio e os mecanismos para a cobrança de impostos, além de prover alguns serviços como saúde e educação. Por fim, procurou manter uma postura amistosa tanto com os russos quanto com os ingleses, procurando deixar claro que um governo central sob o seu comando seria o melhor para todas as partes. Conforme sublinha Saikal (2004: 37), o domínio de Abdur Rahman foi brutal e absoluto, baseado primariamente na coerção e apoiado por uma rede de espiões, fatos que Ihe outorgaram o título de 'Amir de Ferro'.

As vicissitudes da conjuntura internacional uma vez mais iriam influenciar fortemente a trajetória do Afeganistão. A eclosão da Primeira Guerra Mundial na Europa (1914-1918) e a Revolução Russa (1917) tiveram peso fundamental nas políticas externas tanto da Inglaterra quanto da agora denominada União das Repúblicas Socialistas Soviéticas (URSS). Enquanto a primeira, ainda que vitoriosa após a guerra, encontrava-se extremamente debilitada devido aos custos do conflito bélico, a última passara por convulsões intestinas cuja principal reverberação fora a derrocada do regime czarista e a tentativa de implantação do primeiro regime socialista da história ${ }^{41}$. Fatos de tamanha magnitude certamente refletiriam no governo de Cabul.

Dentre as primeiras e principais ações do governo bolchevique destacam-se a denúncia dos acordos firmados pelo regime czarista. Tais denúncias incluíam todos os tratados e convenções firmados com a Inglaterra e que formataram o Estado no Afeganistão. Ademais, para os bolcheviques, o

\footnotetext{
${ }^{41}$ Para maiores detalhes sobre este período, a referência é Hobsbawn (1995).
} 
Afeganistão tinha uma grande importância estratégia visto que havia o receio de que os ingleses utilizassem o território afegão para chegar até Moscou e derrubar o regime implantado após a Revolução de 1917 além de poder ser utilizado como corredor para se atingir as colônias inglesas na Índia.

O governo afegão, liderado agora por Habibullah (1901-1919), seguido por seu filho Amanullah (1919-1929) e atento a todas essas vicissitudes, procurou aproveitar-se das circunstancias que o sistema internacional em transformação apresentara. A principal meta ansiada pelo governo era a independência das suas relações exteriores no tocante à Inglaterra.

O governo de Habibullah, diferentemente de seu antecessor, Abdur Rahman, fez menos uso do terror e violência para impor seu domínio, possibilitando a re-emergência de lideranças religiosas e tribais que até então eram extremamente reprimidas. Ademais, durante seu reinado, uma classe de intelectuais separada do clero começara a se desenvolver no país, incluindo membros da família real. Estas pessoas foram treinadas no exterior para poderem gerir e administrar o aparelho estatal afegão e seus contatos com outros países resultaram na percepção de que o Afeganistão precisava modernizar-se aos moldes de outros países, tais como a Turquia. Todavia, a política de cooperação de Habibullah com a Inglaterra dificultava que novos avanços fossem realizados, desde os almejados pelos intelectuais até aqueles ansiados pelos clérigos e chefes tribais, cuja principal ambição era a reversão do status quo mantido frente ao sistema internacional. Destarte, o resultado foi o assassinato de Habibullah em 20 de janeiro de 1919, o qual estava temeroso em iniciar as reformas e declarar a independência do país perante a Inglaterra.

Amanullah, filho de Habibullah e membro dos Jovens Afegãos ${ }^{42}$, grupo formado por parte da intelectualidade do país e que almejava modernizar o Afeganistão, conseguiu tomar o trono e declarar a independência do país, a qual foi prontamente reconhecida pela URSS embora recusada pela Inglaterra. A recusa inglesa levou Amanullah a comandar um levante nas áreas tribais demarcadas pela Linha Durrand e que definiam as fronteiras com as

\footnotetext{
${ }^{42}$ A modernização da Turquia, comandada por Mustafá Kemal Ataturk e pelos Jovens Turcos foi um dos parâmetros seguidos pela intelectualidade afegã. Para maiores detalhes sobre a Turquia e a modernização no mundo muçulmano, Demant (2004), Lewis (1996) e Hourani (1994).
} 
possessões inglesas na Índia. Os ingleses enviaram tropas à região, culminando na eclosão da Terceira Guerra Anglo-Afegã, cuja duração não foi maior que um mês (maio de 1919 a junho de 1919). Se o conflito teve tão curta duração, deve-se ao fato de que a Inglaterra encontrava-se esgotada após a Primeira Guerra Mundial, assim como as forças afegãs não tinham capacidade suficiente para vencer os invasores.

Assim sendo, a resultante foi o reconhecimento inglês da independência afegã, ainda que os anseios de Amanullah para anexar as áreas além da Linha Durand não fossem atendidos pela Inglaterra. Além de abrir mão destes territórios, outra consequência assaz problemática foi o término dos subsídios ingleses para o Afeganistão, que até então representavam a maior parte da receita do governo. Amanullah, conforme salienta Rubin (2002), passou a receber assistência técnica e militar de diversos países, como a URSS, Turquia, Alemanha, França e Itália, mas ainda eram insuficientes para manter e ampliar a base econômica e militar do Estado. O governo também procurou aumentar suas ligações com os EUA, que já caminhava a passos largos para se tornar uma grande potência. Contudo, Washington não via 0 governo em Cabul como prioridade de sua política externa, além de enxergar o Afeganistão enquanto pertencente à esfera de influência inglesa. Assim sendo, o governo optou por buscar outras fontes de renda, principalmente via abertura do país para o comércio internacional e um modelo de acumulação de capital capitaneado pelo Estado.

O Estado passara então a tentar criar vínculos mais profundos com a sociedade, por meio da tributação da agricultura e aumentando os impostos diretos nas propriedades e nos animais, o que, conforme Rubin (2002: 55), representava 5/8 de todas as receitas domésticas em 1926. Além disso, procurou ampliar a rede de transportes no país para que facilitasse 0 comércio e a projeção de poder do Estaddo dentro do território, impedindo que tribos próximas às áreas fronteiriças continuassem a cobrar taxas de caravanas que passassem pelas regiões mais distantes da capital. Foi durante seu reinado que o país ganhou sua primeira constituição (1921), subordinando até mesmo as ações do rei às leis, e quando foi promulgada proporcionou toda a regulamentação administrativa para as operações governamentais. Conforme podemos notar, Amanullah ambicionava criar fontes internas de receita e, 
consequentemente, garantir o monopólio da tributação dentro de um território que, conforme Elias (1993), juntamente com o monopólio do uso da violência legítima, são os pilares dos Estados.

No mesmo período, outros países muçulmanos apresentaram trajetórias semelhantes para enfrentar o avanço europeu. A Turquia, inspiração para o Afeganistão, tornou-se um Estado laico. Em 1930 a Sharia foi substituída por leis positivas, derivadas de modelos europeus. Tal fato se deveu em grande parte ao controle e às reformas que Kemal Ataturk impôs ao país: além de fechar grande parte das madrassas, suprimiu as ordens sufi e forçou homens e mulheres a se vestirem à maneira ocidental. Casos criminais, cíveis e comerciais eram decididos de acordo com códigos e procedimentos europeus e a autoridade da Sharia e dos juízes que a utilizavam limitava-se a questões de status pessoal.

Em um outro extremo, encontramos a Arábia Saudita. Fundado em 1932 pela família dos Saud, o país tem como forma dominante do Islã o Wahhabismo. Formulada por Muhammad ibn Abd al-Wahhab, a doutrina tem como principal objetivo a volta radical aos fundamentos do Islã com base na interpretação estritamente literal do Alcorão e na tradição muçulmana dos primeiros tempos. Contudo, com o advento do petróleo, muitas mudanças ocorreram no país. Os EUA se tornaram um grande parceiro comercial e os dólares que adentraram no país mudaram sua geografia, com o surgimento de grandes arranha-céus e indústrias petrolíferas, mas mantiveram Meca e Medina sob a guarda da Casa de Saud.

Não obstante, no caso do Afeganistão, mudanças tão profundas vindas de um Estado que até então era uma instituição estranha à população e que pouca confiança tinha da sociedade do país desembocaram em confrontações com as tribos e etnias que controlavam porções significativas do território afegão e que não estavam nada confortáveis com a expansão da capacidade de tributação do governo. Também problemáticas para a situação de Amanullah foram as reformas modernizantes realizadas em áreas como a educação e regulamentação social, cuja principal conseqüência foi incitar a ira do clero do país. Segundo Ewans (2002: 128-129): 
"Amanullah deu atenção considerável para a educação, criando colégios voltados para a educação secundária assim como para o ensino das mulheres, além de enviar vários afegãos para estudar em outros países. Introduziu um currículo secular e trouxe professores da França, Alemanha e Índia. Procurou aumentar os direitos das mulheres e outorgou diversas regulamentações contrárias à escravidão e ao trabalho escravo".

As reações internas a tais reformas começaram a solapar o apoio que Amanullah possuía. Medidas como a monogamia obrigatória e o uso de trajes ocidentais para os funcionários do governo batiam de frente com os ditames de uma sociedade deveras patriarcal e conservadora. Por fim, suas tentativas em fortalecer o exército também fracassaram: Rubin (1988) argumenta que, diferentemente de Abdur Rahman, Amanullah, seguindo orientações de conselheiros turcos, não priorizou aumentar a lealdade das tropas, focando em mudanças na forma de conscrição, procurando centralizar o processo por meio de estruturas estatais e diminuindo o papel que lideranças tribais até então possuíam. Diversos conflitos emergiram no país e a ineficácia do governo de Cabul em findar com as sublevações, culminou na deposição de Amanullah e seu concomitante exílio na Itália.

Liderados por Habibullah Kalakani, mais conhecido como Bachaye Saqao, a revolta que derrubou o governo de Amanullah teve como um de suas principais características a composição majoritariamente Tajik do grupo que governaria o país por quase dez meses (17 de janeiro a 13 de outubro de 1929). Todas as reformas modernizantes e secularizantes realizadas durante 0 governo anterior foram revogadas, ainda que a autoridade de Bacha-ye Saqao não se estendesse muito além das regiões próximas a Cabul. Com um governo sustentado pela coerção, sem apoio dos Pashtun e com pouca receita em caixa devido às reformas de Amanullah, ao fim dos subsídios ingleses e ao fracasso em se fixar um monopólio de tributação, minaram o já fraco governo e rebeliões freqüentes findaram com o interregno Tajik no Afeganistão. Conforme Ewans (2002:136), o regime de Bacha-ye Saqao foi caracterizado pela anarquia, pilhagem e terror.

Assim, de 1929 até 1978 o Afeganistão foi governado por membros da família Musahiban, majoritariamente Pashtun e descendentes de 
Ahmad Shah Durrani, primeiro governante afegão. Nadir Shah assumiu o governo imediatamente após a queda de Bacha-ye Saqao e, ainda que comungasse dos ideais modernizantes outrora pregados por Amanullah, procurou meios distintos para empregá-los. Por conseguinte, procurando evitar os embates diretos com as idiossincrasias da sociedade tribal afegã que haviam apoiado sua ascensão ao poder, os Musahiban optaram por buscar suporte e financiamento no sistema internacional, para assim fortalecer o Estado sem depender das forças intestinas presentes no país e iniciar um processo de transformação Top-Down (de cima para baixo). Conforme Rubin (1988: 1200), este mini Estado-nação passaria a depender cada vez menos da remanescente sociedade camponesa-tribal.

Dessa forma, além de anular todas as reformas sociais propostas por Amanullah, revogando a ampliação dos direitos femininos e resgatando o uso das vestimentas tradicionais do país para aplacar a ira das principais lideranças tribais, Nadir Shah procurou manter boas relações com a Inglaterra e URSS e conseguir os subsídios necessários para levar adiante as transformações que objetivava implementar no país. Ademais, Nadir Shah ambicionava aumentar os laços do país com os EUA. No entanto, apenas em 1934 Washington reconheceu o governo dos Musahiban, mas não enxergava a necessidade de abrir uma missão em Cabul, uma vez que, na opinião do Departamento de Estado (apud SAIKAL, 2004: 103), o Afeganistão é sem dúvida o país mais descontrolado e hostil no mundo hoje.

$\mathrm{Na}$ inexistência de ameaças externas, o governo pôde concentrar-se na estabilização do interior do país, principalmente nas regiões majoritariamente Tajik, com auxílios ingleses para a reconstrução do exército e, em menores proporções, subsídios alemães, franceses e italianos. Todavia, ainda que boa parte das revoltas tivessem sido amainadas, seja pelo aprisionamento e execução dos inimigos ou mesmo pelo suborno dos mesmos, em 1933 Nadir Shah foi assassinado, deixando o comando do país a seu filho, Mohammad Zahir Shah, então com 19 anos. Durante as duas primeiras décadas de seu reinado, o país esteve efetivamente na mão de seus tios: Mohammad Hashim governou autocraticamente até 1946 quando Shah Mahmud o substituiu, convocando eleições e governando até 1952, período conhecido como Parlamentarismo Liberal, caracterizado pela presença de 
Zahir Shah enquanto rei e a criação do cargo de primeiro-ministro, o real responsável pelo governo.

Durante a Segunda Guerra Mundial (1939-1945), apesar de simpatias para com o regime nazista de Hitler, o Afeganistão manteve-se neutro. Não obstante, após o ataque alemão à URSS em 1941 e a entrada soviética na guerra ao lado dos Aliados, tornou-se inviável a continuação de vínculos afegãos com a Alemanha nazista. Logo, o governo de Cabul expulsou do país todos os cidadãos de países do Eixo, ainda que continuasse a pregar a neutralidade afegã no conflito. A formatação de um novo sistema internacional cuja principal característica era o deslocamento do eixo de poder para os EUA e a URSS, assim como a concomitante divisão do globo em áreas de influência devido à bipolaridade que agora marcaria as relações internacionais, resultara numa revisão do posicionamento externo afegão, mas não em sua estratégia de construção estatal e desenvolvimento do país: o governo de Cabul ainda buscaria no sistema internacional as receitas para o país. Conforme destaca Rubin (1988: 1201), se em 1926 os tributos internos representaram 62,5\% da receita total do país, no período compreendido entre 1952-1953 tal montante decresceria para $18.1 \%$, caindo para cerca de 7\% em 1958 e atingindo incríveis $2 \%$ na década de 1970. Tal situação possibilitou cunhar o Afeganistão como um Rentier State, caracterizado por uma economia dependente essencialmente de rendas externas e na qual o governo é o principal destinatário de tais financiamentos (SAIKAL, 2004: 284). No caso do Afeganistão, o Estado pagava os soldados e burocratas com a receita oriunda da ajuda externa, vendas de gás natural e taxas na exportação de alguns commodities.

No decorrer da Guerra Fria (1947-1989), o Afeganistão era considerado um país do Terceiro Mundo e oficialmente estava inserido no Movimento dos Países Não-Alinhados. Todavia, segundo Rubin (2002), a administração Kruschev (1943-1964) proveu suporte para que lideranças nacionalistas do Terceiro Mundo enveredassem pelo caminho não-capitalista de desenvolvimento (protecionismo e estatismo), além de demonstrarem um viés anti-ocidental. Dentro dessa conjuntura, as lideranças afegãs, principalmente após o advento de Daoud Khan ao cargo de primeiro-ministro em Cabul em 1953 e com o fim do Parlamentarismo Liberal, enquadraram-se 
nos quesitos pregados pelo Kremlin: o Afeganistão foi o primeiro país a receber os auxílios soviéticos após o final da Segunda Guerra Mundial ${ }^{43}$. Logo, as ligações do país com o mercado internacional, principalmente via exportação de commodities como algodão e produtos têxteis, proporcionavam aos cofres afegãos a receita suficiente para pagar suas despesas ordinárias. Por outro lado, as conexões com o sistema internacional, principalmente com Moscou, permitiam que o governo empreendesse suas políticas desenvolvimentistas, desde a construção de infra-estrutura, passando por investimentos na educação e saúde, culminando no treinamento e modernização do exército do país. Se as ligações do Estado com o sistema internacional tornavam-se cada vez mais estreitas, a relação com a sociedade do país praticamente desaparecia. Conforme Rubin (1988: 1204):

"Somente a ajuda externa proporcionou à Daoud a capacidade para levar adiante as políticas de construção estatal que tanto ambicionava: centralização do controle dos meios de violência num moderno e bem equipado exército, fortalecimento da agricultura comercial e das exportações por meio de investimentos em infraestrutura econômica, tais como represas e estradas; construção de empresas estatais em detrimento de associações com o capital externo; expansão de um sistema educacional moderno para treinar os recursos humanos necessários para as novas instituições do país; e a criação de um sistema nacional de transportes e comunicações".

Para que tais metas pudessem ser atingidas, muitos conselheiros estrangeiros adentraram o país, principalmente soviéticos ${ }^{44}$, para coordenar projetos na área militar, econômica e educacional. Assim sendo, se, de um lado, a independência do Estado da sociedade tribal aumentava cada vez mais, de outro, surgia uma emergente classe de intelectuais, cuja principal tarefa seria lidar com o aparelho estatal em criação. Oficiais do exército, burocratas e professores começaram a desempenhar funções importantes no Estado e passaram a ter um peso importante no país e a clamar por oportunidades de

\footnotetext{
${ }^{43}$ Esta mesma política externa soviética de financiar lideranças do Terceiro Mundo redundou nos apoios à Nehru na Índia e à Nasser no Egito.

${ }^{44}$ Além da entrada de conselheiros soviéticos, muitos afegãos foram treinados na URSS. Segundo Saikal (2004: 124), até 1979, 6.000 civis e 4.000 militares foram treinados na URSS.
} 
participação e representação política. Associados a tais tensões internas, eventos importantes no cenário internacional começaram a minar o governo de Daoud.

Desde 1947 o Paquistão tornara-se independente do Índia e, após o final da Segunda Guerra Mundial, a Inglaterra se retirara do subcontinente indiano. O vácuo deixado por Londres foi a oportunidade que os EUA viram para se inserir na região e contrabalançar o peso soviético, forjando importante laços estratégico-militares com o Paquistão, Irã e Turquia. Ademais, Washington vislumbrava o Afeganistão como de menor importância diante de seus outros aliados na região e declinou dos pedidos de assistência enviados por Daoud. A recusa norte-americana redirecionou as atenções afegãs para Moscou não apenas com relação ao auxílio externo: uma das metas mais prezadas de Daoud era a revisão da Linha Durand, que agora dividia os territórios afegão e paquistanês e que ganhara suporte soviético. Tal revisão era inviável com a estratégia paquistanesa de unir todas as províncias do país. O embate frente à questão fronteiriça alcançou grandes proporções, agravando o já débil relacionamento entre Cabul e Islamabad. As fronteiras entre os dois países foram fechadas em setembro de 1961 e uma guerra só foi evitada devido à mediação iraniana, apoiada pelos EUA e URSS.

Estas tensões internacionais prejudicaram muito a economia do país, que dependia das exportações dos commodities cujo escoamento se dava pelo porto de Karachi, agora em território paquistanês. Somada à queda de arrecadação, devemos ter em mente a pressão feita pela intelectualidade do país, contrária não apenas a um conflito bélico com o país vizinho, mas também revoltada com o domínio autocrático e coercitivo de Daoud. Tal conjuntura proporcionou ao outro ramo dos Musahiban, liderados por Mohammed Zahir Shah, demandar a saída de Daoud do poder, que de fato ocorreu em 09 de março de 1963.

De 1963 a 1973 o Afeganistão passou pelo período conhecido como Nova Democracia, comandado pelo rei Zahir Shah e pelo primeiroministro Mohammed Youssuf. Neste período o país ganhou uma nova constituição em outubro de 1964, seguido da criação de uma Câmara do Povo, com 216 representantes eleitos por sufrágio, e da Câmara dos Anciãos, constituída por 84 pessoas eleitas pelo povo e mais uma parcela indicada pelo 
rei e pelas Assembléias Provinciais. Como salienta Rubin (2002), a expansão dos direitos de representação e participação política levadas a cabo por Zahir Shah era o reconhecimento de que, com a ampliação das atividades do Estado e a importância cada vez maior dos intelectuais e das classes tradicionais na política interna, novas formas de legitimação do governo eram necessárias. Não obstante, ainda seguindo o raciocínio de Rubin (2002: 73):

"Os latifundiários que dominavam o parlamento não se enxergavam enquanto parte do Estado, o qual deveria ser governado coletivamente. Pelo contrário, enxergavam sua posição como uma oportunidade para utilizar sua influência para reduzir a presença intrusiva do aparato estatal em suas províncias além de supervisionar a aplicação dos recursos externos em seus domínios. Contudo, a assistência externa declinou fortemente a partir de 1965, eliminando a habilidade do governo em, por meio da distribuição desses bens, angariar apoio das lideranças internas e aliviar $o$ descontentamento público".

Destarte, os 10 anos da chamada Experiência com a Democracia ${ }^{45}$ (SAIKAL, 2004) foram extremamente turbulentos. Internamente, a abertura política, além de exacerbar a insatisfação das lideranças do interior do país, marcou o surgimento da organização comunista do país, o Partido Democrático do Povo Afegão $(P D P A)^{46}$, contrário à manutenção da monarquia no país. Em 1967, após um racha interno o PDPA dividiu-se, dando origem ao Khalq (Massas), comandado por Nur Muhammad Taraki e Hafizullah Amim, e ao Parcham (Bandeira), liderado por Babrak Karmal. De outro lado, movimentos islâmicos, oriundos majoritariamente da Faculdade de Estudos Islâmicos da Universidade de Cabul, começaram a se proliferar no território e a demandar

\footnotetext{
${ }^{45}$ Hammond (1987) questiona a qualidade da democracia implantada por Zahir Shah neste período. Segundo dados apresentados pelo autor, as eleições realizadas em 1965 e 1969 tiveram apenas $10 \%$ da participação do eleitorado do país e a eleição que deveria ocorrer em 1973 não foi realizada. O parlamento era dominado por conservadores que bloqueavam a legislação progressista e, quando uma lei liberal era aprovada o rei a vetava. A imprensa estava longe de ser livre e os mecanismos de controle se tornaram particularmente severos depois das eleições de 1969. A constituição de 1964 de maneira alguma limitou os poderes do rei, que não era responsável perante ninguém.

${ }^{46}$ Zahir Shah jamais legalizou a criação de partidos políticos no Afeganistão. No entanto, na primeira eleição, em 1965, o PDPA não participou formalmente, mas quatro de seus integrantes foram eleitos.
} 
participação política. Dentre suas principais lideranças, destacavam-se Burhabuddin Rabbani e Gulbundin Hekmatyar.

As tensões entre comunistas e islamistas e suas pressões em direção ao rei conjugadas com um quadro econômico que continuamente se deteriorava minaram qualquer esforço do governo para lidar com a crise. 0 Estado, deveras dependente de assistência externa para continuar em pé, se viu, a partir de 1964, sem as receitas que conseguia levantar das potências. Enquanto os $E U A^{47}$, que já contribuíam pouco, retiravam investimentos do país que no seu auge atingiram 2, 35 bilhões de dólares, a URSS cada vez mais aumentava sua influência no país. A partir do final da década de 1960, para que um governo passasse a receber assistência soviética, era mister a criação de um partido comunista pró-Moscou. O PDPA e suas divisões vieram para preencher esta lacuna. Sem conseguir lidar com os impasses políticos originados por tal conjuntura, Zahir Shah não conseguiu evitar que Daoud Khan uma vez mais tomasse o poder. Sem nunca esconder que ambicionava retornar ao governo, e aproveitando-se de que o rei encontrava-se na Itália realizando um tratamento médico, em 17 de julho de 1973, Daoud, apoiado pelo exército, retomou o poder sem derrubar sequer uma gota de sangue (EWANS, 2002: 175).

De 1973 a 1978 Daoud controlou pela segunda vez o país, findando com o regime monárquico e declarando o Afeganistão uma república, assumindo os postos de presidente, primeiro-ministro, ministro das relações exteriores e ministro da defesa. Dentre suas principais metas estavam a eliminação dos grupos islamitas, os quais eram acusados de serem o maior entrave para a modernização do Estado, e a revisão da questão fronteiriça com o Paquistão. O Parcham, que havia proporcionado apoio para Daoud é recompensado inicialmente com vários cargos no governo; contudo, em 1977 o presidente ruma para a direita e abandonando os comunistas que até então eram a principal base de suporte para seu governo. Uma nova constituição estabelece um parlamento unicameral e apenas um partido oficial, o Hezb-iInqilab-i-Milli (Partido Revolucionário Nacional).

\footnotetext{
${ }^{47}$ Ainda que dessem preferência ao Paquistão como aliado regional, a partir da década de 1950 os EUA começaram a realizar alguns investimentos no país, tentando contrabalançar a influência soviética no Afeganistão.
} 
A manutenção das receitas externas, as quais estavam diminuindo cada vez mais, era um tema particularmente problemático para 0 governo afegão. A economia continuava em recessão ao mesmo tempo em que a URSS, por meio de seus investimentos e conselheiros no país, aumentava sua presença no país. Ansiando diminuir a dependência vis-à-vis Moscou, Daoud iniciou conversações com o Irã, cujos petrodoláres estavam transformando Teerã numa potência regional. Um acordo firmado entre os dois países, e encorajado pelos EUA, direcionava 2 bilhões de dólares para um período de 10 anos (EWANS, 2002). Todavia, para a URSS o novo direcionamento afegão em nada agradava o Kremlin porquanto aumentava a presença iraniana - e, consequentemente, norte-americana - no país.

Internamente, o segundo governo de Daoud enfrentou resistências de todas as partes da população. Por ter se voltado contra os comunistas, perdeu boa parte de sua sustentação; por pregar políticas modernizantes e de cunho secularizantes, fomentou a antipatia dos movimentos islamitas. Além de termos em mente o caráter do Estado Afegão, dependente de auxílios externos, os grupos de resistência internos, de certa forma, compartilhavam esta mesma característica. Segundo Rubin (2002: 81), um Rentier State produz Rentier revolutionaries. Isto significa que no caso do Afeganistão, os movimentos contrários ao governo em Cabul eram sobremaneira incentivados a se rebelarem devido sobretudo às influências externas. Consoante o raciocínio do autor (2002: 81):

"Diferentemente dos revolucionários franceses, russos ou chineses, as oportunidades para os afegãos - assim como para as suas lideranças - permitiam que eles buscassem apoio em fontes no sistema internacional, não naqueles descontentes na sociedade do país $^{48, "}$

\footnotetext{
48 Rubin (2002: 19), com o trabalho realizado por Skocpol (1985) em mente, faz uma comparação interessante com a Revolução Francesa (1789-1799) para deixar claro este ponto. Segundo o autor, em 1789, pouco antes da Queda da Bastilha, $85 \%$ dos franceses eram camponeses e a agricultura representava $60 \%$ da produção total do país, com as terras divididas em pequenas propriedades. Em 1978, pouco antes do golpe que derrubou Daoud, $85 \%$ dos afegãos eram camponeses ou nômades, e a agricultura representava iguais $60 \%$ da produção. Não obstante, os tributos na França incidiam principalmente nos camponeses, enquanto que no Afeganistão os camponeses praticamente não pagavam impostos. Assim, se na França os revolucionários tinham um incentivo para buscar apoio da população, no Afeganistão não havia a mesma situação e o único suporte viável era a ajuda externa.
} 
Por conseguinte, unindo-se os descontentamentos tanto do Khalq e Parcham com os da URSS, a oposição à Daoud cresceu, culminando nos eventos que entrariam para a história como a Revolução Sawr. O leitmotiv para o golpe de Estado surgiu quando ficou claro para os soviéticos que Daoud iria retirar todos os comunistas do exército, principal instituição estatal do país e que propiciava os meios de controle social para o governo. Assim, ao sentir que ficaria sem mecanismos para controlar os rumos do país, a URSS providenciou a reunião do Khalq e do Parcham ao redor do PDPA e, entre os dias 27 e 30 de abril de 1978, Daoud e toda a sua família foram assassinados, findando com a dinastia que desde os tempos de Ahmad Shah Durrani controlara o país. Surgia então a República Democrática do Afeganistão.

O governo controlado pelo PDPA durou pouco. $\mathrm{Na}$ inexistência de um inimigo a ser combatido, o partido voltou a se dividir nas mesmas duas facções. Nur Muhammad Taraki, ao sagrar-se presidente, isolou todos os membros do Parcham dos altos cargos do governo e, segundo Ewans (2002: 194):

"Começou a impor um reino de terror contra seus inimigos. Grande número de oficiais militares, religiosos, antigos políticos e profissionais liberais foram presos. Muitos fugiram do país. No interior, religiosos e líderes seculares também eram alvos".

Destarte, medidas como a reforma agrária, mudanças na lei do casamento e na educação do país, principalmente após a introdução do marxismo no sistema de ensino de uma sociedade majoritariamente muçulmana provocaram a ira da maior parte de uma população que via o Estado como uma instituição intrusiva, nefasta para o controle social exercido pelas lideranças tribais, resultando no aumento da oposição ao governo. Por sua vez, a URSS, receosa acerca dos rumos do país, procurava por meio dos conselheiros que possuía no país, mudar a orientação do governo de Taraki. Contudo, Hafizullah Amim, segundo homem na hierarquia do Khalq e procurando assumir o posto de presidente, assassinou Taraki o que resultou na fúria dos altos escalões do Kremlin. Ao mesmo tempo, o governo de Cabul perdera o controle do interior do país, a partir de agora controlado pelos 
mujahidin, que ulteriormente, viriam a desempenhar papel fundamental na trajetória política do Afeganistão.

Alarmados com tal conjuntura, numa reunião em 08 de dezembro de 1979, as principais lideranças no Kremlin levantaram a alternativa de invadir o país, a qual foi ratificada pelo partido no dia 12 do mesmo mês. Assim, em 24 de dezembro de 1979, unidades da 105 divisão aérea soviética invadiram o Afeganistão. Dentre os motivadores de cunho sistêmico para a invasão, conforme aponta Saikal (2004), estavam: (1) o advento do Irã sob o comando do Aiatollah Khomeini e a possibilidade de que o Afeganistão se tornassem suscetível à influência de um regime fundamentalista; (2) as políticas pró grupos islamitas empreendidas pelo governo paquistanês e os laços crescentes entre Islamabad e Pequim, governos que não haviam reconhecido o regime do Khalq; e (3) o aumento da presença norte-americana no Golfo Pérsico, principalmente após a Revolução Iraniana (1979). Internamente, sem sombra alguma de dúvida, o iminente colapso do governo controlado pelo Khalq e a possibilidade de ascensão de um regime fundamentalista no Afeganistão cujas ações viessem a ameaçar todos os investimentos soviéticos no país foram os principais motivadores para a invasão. Assim foi possível para Babrak Karmal, com o apoio soviético, assumir o governo.

O fracasso do governo anterior em destruir todas as formas concorrentes de controle social existentes no país - principalmente as lideranças tribais - somente fomentou o ódio que a sociedade afegã tinha para com o Estado. Agora, a presença de uma potência em solo afegão era apenas mais um motivo para levar as massas a se voltarem contra o governo central. Dessa forma e segundo dados apresentados por Rubin (2002), cada um dos dez anos em que a URSS ocupou o Afeganistão custaram aos cofres de Moscou a bagatela de 5 bilhões de dólares, necessários para coibir as rebeliões no interior do país e manter alguma ordem nos maiores centros. Necessário para o combate à insurgência, esta financiada por países como EUA, Arábia Saudita e Paquistão, era a recriação do exército no país. O exército e a aeronáutica soviéticos treinaram um emergente contingente, ainda que este sofresse devido à deserções. Para o controle das cidades, foi criada uma polícia secreta (KHAD), nos moldes da KGB. Ademais, os conselheiros tinham em mente a reestruturação do partido comunista no país, da economia 
e da educação. Todos os gastos do governo afegão seriam bancados pela ajuda externa e pela venda de gás natural, mantendo-se a dependência do país vis-à-vis Moscou.

O fim da Détente e a Rebipolarização ocorrida com o advento à Casa Branca da administração republicana capitaneada por Ronald Reagan (1981-1989) intensificaram os embates da Guerra Fria. Como bem apontado por Lima (1996), a rivalidade entre EUA e URSS deu-se principalmente em questões estratégico-militares; no quesito economia, a superioridade norteamericana sempre foi saliente. Assim, ao final da década de 1980, Moscou não conseguia mais equipar-se ao seu principal rival uma vez que a economia soviética caminhava rumo à recessão generalizada. Agregando os gastos oriundos da ocupação no Afeganistão, a permanência do exército vermelho tornara-se insustentável.

A resistência interna, por sua vez, também atrapalhou os planos do Kremlin. Mujahidin ${ }^{49}$, ou combatentes da liberdade, foi a designação dada às milícias que se formaram em diversas regiões do Afeganistão para combater os soviéticos. A resistência, contudo, não atuou de forma unificada. Além de poder ser caracterizado como um mosaico étnico ${ }^{50}$, os diferentes grupos mujahidin comungavam entre si apenas a hostilidade com relação aos soviéticos; nem a fé no Islã foi capaz de fazer com que as partes superassem suas diferenças pessoais e étnicas (EWANS, 2002).

Tentando contornar as dificuldades não apenas encontradas no Fiasco Afegão, alcunha dada à ocupação, mas também já vislumbrando a possibilidade de derrocada da URSS, Gorbachev operou mudanças substanciais na política externa de seu país, denominadas New Thinking ${ }^{51}$. Segundo Wallander e Prokop (1993: 67):

\footnotetext{
${ }^{49}$ Mujahidin é o plural. O singular é mujahid.

${ }^{50}$ Dentro de um universo de 31.889 .923 habitantes, a população afegã é divida em etnias, destacando-se: $42 \%$ Pashtun, 27\% Tajiks, 9\% Hazaras, 9\% Uzbeks, 4\% Aimaks, 3\% Turkmen e $2 \%$ Balochs, além de outras etnias minoritárias (4\%). Dados disponíveis em The Cia Factbook www.cia.gov/library/publications. Acesso em 22/06/2007.

51 Indo mais além, numa tentativa para modernizar o país, duas grandes reformas foram executadas. A Glasnost, uma política de abertura, de transparência no trato das questões políticas soviéticas, além de uma campanha contra a corrupção e a ineficácia na administração do país; e, por fim, a Perestroika, um plano de reestruturação do sistema político e econômico da URSS.
} 
"O New Thinking alterou os princípios mais básicos da política externa marxista-leninista soviética. Não abandonou o ideal socialista em assuntos de cunho doméstico do país, mas declarou que a política externa não tomaria para si o pressuposto de que a condição fundamental do sistema internacional era o conflito de classe. Rumando para outra direção, valores humanitários comuns tais como a luta contra uma guerra nuclear mundial e desenvolvimento econômico pacífico - foram declarados prioritários vis-à-vis qualquer clivagem socialista-capitalista".

Para o Afeganistão, tais reordenamentos na política externa soviética objetivavam, conforme Saikal (2004), três metas. Primeiramente, ambicionava-se uma retirada honrosa do Afeganistão e, para tanto, era necessária a sobrevivência do regime do presidente Mohamed Najibullah, apoiado pelo Kremlin. Em segundo lugar, para a efetivação do primeiro objetivo, fazia-se necessário o envolvimento de outros países para a resolução do Fiasco Afegão. Por fim, propunha-se culpar o governo de Brezhnev pela ocupação no Afeganistão, declarando tal ação como um erro.

Por outro lado, o Fiasco Afegão fez com que Washington revisse sua política externa para a região. Se, com a invasão soviética, os EUA optaram por financiar a resistência além de propiciar treinamento para boa parte dela ${ }^{52}$, a falência da URSS determinou a diminuição do montante de recursos para o país, ao mesmo tempo em que deixava sob responsabilidade paquistanesa o manejo de futuros financiamentos (SAIKAL, 2004). Como bem aponta Ewans (2002: 244):

"Com a Guerra Fria chegando ao fim, nenhuma das potências possuíam qualquer interesse estratégico no Afeganistão, ainda que os russos continuassem apreensivos com a possibilidade de que Cabul se tornasse um santuário para o extremismo islâmico, assim como o Irã. (...) A partir de 1991, a atenção norte-americana direcionou-se do Afeganistão para a invasão do Kuwait e a Guerra

\footnotetext{
${ }^{52}$ Após a invasão soviética, os EUA iniciaram um programa de ajuda militar e econômica para o Paquistão além de propiciar assistência logística para a resistência afegã. A CIA teve papel importante, coordenando a entrega de armas para os grupos de resistência sunitas, os quais eram maioria dentro do Afeganistão e que possuíam base na fronteira com o Paquistão. Ademais, com a ascensão do republicano Ronald Reagan, eleito com uma agenda fortemente anti-soviética, a ajuda ao Paquistão e aos mujahidin continuaram em rota crescente. Para maiores detalhes, sugere-se COLL (2004), RUBIN (2002) SAIKAL (2004) e WRIGHT (2007).
} 
do Golfo, enquanto os russos estavam mais preocupados com o fim de sua hegemonia do Leste Europeu e com os possíveis acontecimentos dentro da própria URSS."

Dessa forma, após a assinatura dos Acordos de Genebra em 14 de abril de 1988, firmou-se a retirada das tropas soviéticas do país, processo iniciado prontamente em 15 de maio de 1988. O governo do presidente Najibullah, que substitui o de Babrak Karmal após a invasão soviética em 27 de dezembro de 1979, conseguiu se manter cambaleante, calcado primordialmente no suporte dado por Moscou. Os arsenais deixados no país possibilitaram que o presidente afegão projetasse seu poder pelo território, ainda que fosse continuamente contestado por grupos guerrilheiros presentes no país.

Por conseguinte, com a saída das tropas soviéticas do Afeganistão $0^{53}$, deparamo-nos com um cenário caracterizado por um governo títere, imposto pela superpotência decadente; diversas milícias armadas, cada qual com apoio de grande contingente populacional e com suas fontes particulares de financiamento; e um mesmo objetivo: ocupar o espaço político deixado vago. Conforme salientado por Rubin (2002: x):

"Assim, com a retirada soviética e sua posterior dissolução, e o desengajamento dos EUA, o Afeganistão foi deixado sem um Estado legítimo, sem nenhuma liderança nacional, com múltiplos grupos armados em cada localidade do país, uma economia devastada, e uma população dispersa não apenas no território nacional, como também pelo mundo todo".

O resultado de uma conjuntura conturbada como esta foi a eclosão de uma guerra civil entre as partes. Durante três anos o governo Najibullah conseguiu manter-se no poder; contudo, as milícias continuavam avançando, tomando as principais cidades do país ${ }^{54}$. No início de 1992, EUA e

\footnotetext{
${ }^{53}$ O final da retirada das tropas ocorreu em 15 de fevereiro de 1989.

${ }^{54}$ Rashid (2001) delineia a divisão política do Afeganistão durante o período de guerra civil. 0 centro do país era controlado pelos Hazaras, principalmente a província de Bamyian. Os Pashtun estavam divididos: três províncias próximas à fronteira com o Paquistão estavam sob o comando de uma aliança de líderes mujahidin, enquanto Gulbuddin Hekmatyar controlava uma pequena região ao sul do país. No norte, o general uzbek Rashid Dostum controlava seis
} 
a ex-URSS firmaram um acordo cujo objetivo era cessar tanto a entrega de armas quanto a ajuda financeira para as partes envolvidas no conflito afegão. Sem mais poder contar com ajuda externa, o governo Najibullah perdeu a maior parte de sua sustentação.

Se, de um lado, o governo agonizava, do outro, os mujahidin continuavam sua luta intestina pelo controle do país. Conforme destacam Khalizad e Byman (2000), o conflito ganhara contornos étnicos-sectários, particularmente entre os Pashtun, Tajik, Uzbek e Hazara. Todavia, as diferenças étnico-religiosas dos grupos foram substancialmente incrementadas pela interferência de outros países na dinâmica da política afegã: o modus operandi de potências como Paquistão, Arábia Saudita e Irã contribuiu para exacerbar as diferenças entre as facções.

De acordo com Saikal (1998), o Paquistão teve atuação destacada. A saída da URSS da região deixara um vácuo de poder que Islamabad pretendia preencher. O governo paquistanês objetivava abrir rotas de comércio na Ásia Central e um Afeganistão instável impossibilitaria que o porto de Karachi se tornasse o principal escoadouro da região. Por apresentarem uma composição étnica similar (ambos os países apresentam grande contingente Pashtun em sua população) e pelo fato do Paquistão ter dado apoio logístico à resistência durante a ocupação soviética, Islamabad proveu suporte aos Pashtun durante a guerra civil, principalmente à milícia comandada por Gulbudin Hekmatyar. Destarte, a ascensão de um governo Tajik não era vista com bons olhos pelo Paquistão, que continuou a apoiar Hekmatyar, a despeito de sua ineficiência em assumir o controle do país ${ }^{55}$.

As agendas sauditas e norte-americanas apresentavam convergências com a paquistanesa. Dentre seus principais objetivos, os sauditas objetivavam exportar o Wahhabismo para o Afeganistão e assegurar que o regime xiita iraniano não obtivesse ganho algum na região. Os EUA, por sua vez, apoiavam uma estratégia de contenção ao Irã. O Irã, por sua vez, opunha-se a qualquer esquema em que parecesse estar alinhado com os EUA

províncias e, por fim, outras porções do território afegão eram disputadas por comandantes mujahidin e bandidos, os quais aterrorizam a população local.

${ }^{55}$ Rubin (2002) salienta que Islamabad, além de financiar a milícia de Hekmatyar, deu apoio a outros grupos mujahidin pashtun. Tal estratégia consistia em ter a simpatia de outros grupos, fragmentar ainda mais um possível governo que viesse a emergir e tornar o Afeganistão um satélite do Paquistão. 
e seus aliados na região. Assim, Teerã optou por direcionar uma limitada quantidade de ajuda para o Afeganistão, principalmente para os grupos mujahidin xiitas, os quais pareciam mais suscetíveis à influência iraniana.

A equação formada por um governo fraco e milícias armadas com fontes de financiamento externo culminou na queda do governo de Najibullah, em 15 de abril de 1992. Enquanto o ex-presidente escondia-se no quartel da ONU no Afeganistão, uma coalizão mujahidin liderada por Ahmed Shah Massoud avançou sobre Cabul enquanto milícias no interior do país se rendiam, barganhando lugares no novo arranjo institucional que se vislumbrava. Em 25 de abril de 1992 foi estabelecido o Estado Islâmico do Afeganistão (Islamic State of Afghanistan), presidido por Burhanuddin Rabbani e de maioria Tajik.

Todavia, o novo governo não conseguiu angariar apoio de facções importantes, principalmente dos Pashtun. As milícias argumentavam que estavam sub-representadas na nova divisão de poderes e que não fariam parte de um arranjo político-institucional encabeçado majoritariamente por Tajiks. Dessa forma, o governo do presidente Rabbani conseguiu projetar seu poder apenas na capital e em seus arredores: o restante do país estava dividido entre as demais facções e senhores da guerra.

A perenidade dos conflitos fez com que, em meados de 1994, o Afeganistão caminhasse rumo à desintegração. A infra-estrutura do país assim como toda a sua cadeia econômica encontrava-se deteriorada. Ademais, segundo Ewans (2002), a inabilidade das lideranças mujahidin em alcançarem qualquer acordo para um cessar-fogo entre as partes e a intransigência de Gulbundin Hekmatyar, protegido pelo Paquistão e cuja ambição era tornar-se o presidente do país, diminuíam sobremaneira as possibilidades de findarem os conflitos.

Neste momento crítico, temos o surgimento do Talibã. Em julho de 1994 um líder guerrilheiro havia raptado e estuprado três garotas. A população local recorreu então ao mulá Maulvi Mohammed Omar, o qual recrutou um grupo de 30 estudantes religiosos e, com apenas 16 rifles, atacou a base da guerrilha, resgatou as garotas e enforcou seus raptores, além de confiscar todo armamento e munição encontrados no local. Meses depois, um garoto tornou-se motivo de disputa entre dois outros guerrilheiros, os quais 
queriam sodomizar a criança. Na disputa, alguns civis morreram e uma vez mais Omar foi chamado para resolver a situação. O mulá libertou a criança, executou os guerrilheiros e a partir daí passou a ser requisitado sempre que surgissem disputas locais (RASHID, 2001).

Indignados com o caos e a depravação orquestrados pelas milícias e pelo próprio governo, os Talibã ${ }^{56}$, em sua maioria estudantes oriundos de campos de refugiados na fronteira com o Paquistão, distanciaramse dos mujahidin ao se apresentarem não como um partido que almejava chegar ao poder, mas como um movimento cuja pretensão era reorganizar a sociedade, segundo os preceitos muçulmanos, e findar com a corrupção e os excessos mundanos. Angariando apoio da população, a qual estava extenuada por conflitos intermitentes, o Talibã aumentava progressivamente sua influência pelo território afegão.

Significativa também foi a influência paquistanesa para a consolidação do grupo liderado por Omar. Porquanto Hekmatyar não conseguia ampliar seus domínios no Afeganistão, Islamabad redirecionou suas verbas para os ascendentes Talibã. Comentando a ascensão do Talibã, Wright (2007:251) afirma que graças ao apoio da inteligência paquistanesa, transformou-se de uma milícia populista em um exército de guerrilheiros poderosos $^{57}$. Com tantas variáveis a seu favor, o Talibã tomou Cabul em setembro de 1996, após um cerco de 10 meses. O presidente Burhanuddin Rabbani, juntamente com Ahmed Shah Massoud, instalaram-se no norte, território de maioria Tajik, formando o principal foco de resistência anti-Talibã.

Os Talibã impuseram um regime de terror ao Afeganistão. A despeito dos clamores de Omar e das demais lideranças de que era preciso reislamizar o país, o que se viu foi um regime que desrespeitava os direitos humanos e que abrigava grupos terroristas. Segundo Rashid (2001), crentes de outras fés eram obrigados a usar uma tarja amarela nos braços e muitas vezes eram agredidos nas ruas. Dentre os casos mais notórios de intolerância religiosa

\footnotetext{
${ }^{56}$ Talibã significa estudantes. O singular é Talib.

${ }^{57}$ Os EUA, a priori, viam o Talibã como um possível contrapeso ao Irã na Ásia Central. Conforme Ewans (2002: 256), oficiais norte-americanos, incluindo o sub-secretário de Estado Robin Raphael, tiveram encontros com líderes Talibã e saíram com opiniões favoráveis. De outro lado, os sauditas começaram a financiar o Talibã, também objetivando a contenção da influência iraniana na região. Por fim, ao entender o Talibã como um desafio político-ideológico preparado pela tripé Washington-Riad-Islamabad, Teerã aumentou o seu apoio aos xiitas no Afeganistão, principalmente à milícia comandada por Ahmed Shah Massoud.
} 
constata-se a destruição das estátuas dos Budas de Bamiyan, demolidos sob a justificativa de que impulsionavam a idolatria.

O discurso Talibã também foi utilizado para justificar o extermínio de minorias étnicas. Acusando-as de apóstatas ${ }^{58}$, o Talibã perseguiu boa parte das etnias e religiões minoritárias do país, principalmente aqueles que não fossem Pashtun e fossem contrários ao regime. Neste sentido, os Talibã podem ser entendidos enquanto Novos Guerreiros, segundo terminologia proposta por Kaldor (1999). Diferenciando-se dos Revolucionários, cujo método de ação seria calcado no suporte e obediência da população local, os Novos Guerreiros teriam como plataforma para a ação a dispersão popular, ou seja, a estratégia consistiria sobretudo em livrar-se de todos os oponentes. $O$ assassinato de mais de 6000 Hazaras na província de Bamiyan, durante os anos de 1998-1999, além do seqüestro de cerca de 400 mulheres para servirem como concubinas exemplificam tais atos. Por fim, o Talibã tornou-se refúgio para diversos grupos extremistas de países como a Rússia, Paquistão, China, Irã, entre outros, os quais, ao mesmo tempo em que apoiavam o regime, organizavam-se para levar sua luta para seus países de origem.

A conexão com Osama Bin Laden, fundador da Al-Qaeda, traria conseqüências importantes para o regime. Ao proporcionar abrigo para que Bin Laden treinasse seus militantes e organizasse ataques terroristas a partir do Afeganistão ${ }^{59}$, o Talibã trouxe as atenções mundiais para o país. Em 19 de janeiro de 2000, o Conselho de Segurança das Nações Unidas aprovou a resolução 1333, impondo sanções como a proibição de vendas de armas ao país, o congelamento das finanças do Talibã que estivessem alhures e o cancelamento de todos os vôos ao país. Tal medida se deveu sobremaneira às suspeitas de que o regime dera abrigo à Al-Qaeda para que esta pudesse organizar os atentados contra as embaixadas norte-americanas na África em 1998. Entre outras medidas, o Conselho de Segurança demandava a extradição de Bin Laden. No entanto, apesar das sanções e de muita retórica, pouco se fez de fato para se alcançar as metas das resoluções.

\footnotetext{
${ }^{58}$ A apostasia, o abandona da crença, é considerado um dos piores pecados no Islã.

59 Para três excelentes análises sobre as conexões entre Bin Laden e o Talibã, sugere-se COLL (2004), RASHID (2001) e WRIGHT (2007).
} 
O Talibã viria a cair apenas após os atentados terroristas de Onze de setembro de 2001. A operação Liberdade Duradoura (Operation Enduring Freedom) iniciou-se em 07 de outubro de 2001. Os EUA, conforme salientado por Rubin (2002), esperavam que seus bombardeios fossem suficientes para enfraquecer o Talibã e permitir que a resistência tomasse Cabul. Não obstante, ao final de outubro verificou-se a necessidade de intervenção militar, demandando o envio de tropas para o país. Assim sendo, os Talibã apresentaram pouca resistência; Cabul caiu em 13 de novembro de 2001, mas sem que as principais lideranças do regime, assim como Bin Laden, fossem encontradas. Durante seu período de governo, de uma pequena milícia, os Talibã ampliaram sua dominação para quase $90 \%$ do território do país, ainda que fossem contestados pela Aliança do Norte. Podemos afirmar que no caso afegão, o golpe final que levou à falência do Estado no país foi a intervenção norte-americana, a qual findou com o controle do regime e deixou um vácuo de poder que viria a ser o centro de competições e foco da operação de NationBuilding no país. Contudo, antes de analisarmos a reconstrução afegã, é interessante tecermos algumas reflexões sobre o Estado no Afeganistão.

\subsection{REFLEXÕE SOBRE O ESTADO NO AFEGANISTÃO}

Conforme salientamos nas seções anteriores, os Estados na Europa emergiram como um epifenômeno de agências e estruturas burocrático-administrativas as quais foram o meio utilizado pelos governantes para estender e centralizar o controle sobre a população e assim extrair os recursos necessários para se armarem contra os inimigos externos, criando exércitos permanentes e que iriam se diferenciar, posteriormente, das forças policiais. Velasco e Cruz (2005) argumenta que no processo de centralização estatal europeu, três aspectos foram cruciais, quais sejam, (1) a importância decisiva da pacificação interna para a expansão do capitalismo; (2) o caráter internacional do pacto que assegurou a estabilização das relações políticas em cada unidade territorial; e (3) a centralidade nesse processo do princípio da soberania. No caso do Afeganistão, o processo foi bem diferente, tanto se 
considerarmos a dimensão doméstica, da relação Estado com a sociedade, como se nos depararmos na dinâmica do sistema internacional.

No que tange às relações internas, Saikal (2005) argumenta que poder e política no Afeganistão sempre foram personalizados ao invés de institucionalizados. A autoridade dos regimes que se sucederam no país permaneceu fraca durante a história do país em comparação com a força que possuíam as divisões tribais e sectárias que, de fato, controlavam a maior parte do país. Com raríssimas exceções, dificilmente o governo central em Cabul conseguiu exercer grande controle social sobre todas as porções do território. As tentativas de construção estatal no país, se não possuíam a complacência da maioria das etnias, ao menos dos Pashtun, a majoritária, pelo menos procuravam não ganhar a antipatia das mesmas. Todas as vezes em que os Estado procurou se impor contra a sociedade, conflitos emergiram e as instituições que um governo central procurava criar, principalmente 0 monopólio dos meios de coerção, tendiam a desmoronar.

No que tange ao ambiente externo, é preciso ressaltar que a trajetória de construção do Estado empreendida pelas principais lideranças que governaram o país sempre tiveram que ter em mente a presença de grandes potências ao redor do país. Fossem os moribundos impérios Persa e Mogol, os impérios Britânico e Russo e, posteriormente, EUA e URSS, as vicissitudes do sistema internacional influenciaram na formatação do país, desde a delimitação das fronteiras até as instituições que viriam a emergir. $O$ ambiente externo também, em alguma medida, influenciou a forma como Estado e sociedade se relacionaram no Afeganistão ao longo da história. Conforme salienta Rubin (2002: 120):

"Tendo-se desenvolvido basicamente via o financiamento de potências externas interessadas no potencial do Afeganistão enquanto um tampão político e militar, o Estado praticamente não criou qualquer instituição para a interação com a sociedade. (...). Com exceção das cidades, havia pouca presença policial no país. Não havia partidos políticos nacionais, associações cívicas ou grupos de interesse formalizados. Não havia, em outras palavras, sociedades política e civil que mediassem o relacionamento Estadosociedade". 
Principalmente após a Revolução Sawr e o início do governo do Khalq, o Estado procurou derrubar todas as formas concorrentes de controle social existente no país. Se até outrora os períodos de embate com as lideranças tribais eram intervalados, a partir de então a violência se generalizou. Tal quadro se agravou com a invasão soviética, culminando nos anos de resistência e passando pelo período de guerra civil e governo do Talibã. Rashid (2001) argumenta que toda uma geração, principalmente aqueles nascidos no final da década de 1970, teve suas vidas perpassadas por um período de violência endêmica, no qual todos os grupos procuravam controlar o território do país. Saikal (2004) faz contribuição valiosa ao afirmar que todos os conflitos políticos que emergiram no país eram marcadamente tentativas de se centralizar o poder no país. Ainda que alcunhas como Parlamentarismo Liberal, Nova Democracia ou o Islamismo do Talibã fossem utilizados para angariar apoio das facções, além dos discursos que pregavam a necessidade de modernização do país, tais justificativas eram utilizadas para controlarem o governo central do país. E tal centralização era importante porque ampliava as oportunidades de as lideranças buscarem financiamentos junto ao sistema internacional.

Destarte, podemos caracterizar o período pós-Guerra Fria como um em que diversos grupos continuavam na incessante luta em busca da centralização do poder no país, ou, segundo a elaboração de Elias (1993), uma competição pela monopolização entre as facções em conflito. Desde a guerra civil entre os mujahidin, após a retirada soviética, e chegando ao regime do Talibã, todos buscavam o mesmo objetivo. Os embates que outrora se restringiam ao interior do país, principalmente nas suas montanhas e estepes, atingiram as principais cidades do país. Nesta competição pela monopolização, as partes ainda contaram com as interferências de potências externas que procuravam formatar a conjuntura afegã para melhor atender aos seus interesses. Na ascensão do Talibã, facção que mais perto esteve de controlar todo o território do Afeganistão, a atuação do Paquistão foi fundamental. E mesmo a resistência ao regime comandado pelo mulá Omar contou com apoios externos, principalmente a Aliança do Norte, cujos financiamentos em boa parte advinham do Irã (RASHID, 2001). 
A queda do Talibã também deve ser entendida como boa parte dos demais fracassos de governos anteriores: a partir da constatação de que a Al-Qaeda recebeu suporte do governo afegão, o Paquistão deixou de lado o anterior aliado e passou a fazer parte da Guerra ao Terror proposta pelos EUA. Logo, a ajuda financeira dada por Islamabad cessou e, para piorar ainda mais a situação, o Paquistão apoiou ostensivamente as tropas norte-americanas nas batalhas contra o Talibã, o golpe de misericórdia para o colapso do governo.

Assim, acreditamos que muito antes dos ataques terroristas de Onze de setembro de 2001 o Afeganistão poderia ser entendido como um Estado fragilizado, fraco, falido, da periferia ou qualquer outro adjetivo que sublinhe suas deficiências frente aos demais. No entanto, as origens do problema vão além de políticas públicas equivocadas, regimes de terror que perpassaram a história do país, ou mesmo o aumento da criminalidade e do número de refugiados que o país possui: tais fatos somente serão mais bem compreendidos se levarmos em consideração o processo maior, o qual envolve variáveis internas e externas, ou, parafraseando Cox (1986), devemos entender como o Afeganistão se encaixa no todo. Se quisermos compreender o dilema do Afeganistão e se a comunidade internacional realmente quiser reconstruir o país devemos atentar para as idiossincrasias do processo de construção estatal no país para que as esperanças depositadas no país tornem-se muito mais que apenas parte de uma retórica. 
A

RECONSTRUÇÃO 


\section{AS OPERAÇÕES DE NATION- BUILDING}

"Hoje podemos visualizar a emergência de um novo mundo. Um mundo no qual realmente existe uma real perspectiva de uma Nova Ordem Internacional. Nas palavras de Winston Churchill, uma Ordem Mundial na qual os princípios de justiça e transparência protegem os fracos dos fortes. Um mundo no qual a ONU, livre dos impasses da Guerra Fria, está pronta para cumprir a visão histórica de seus fundadores. Um mundo no qual liberdade e respeito aos direitos humanos acharão seu lar entre todas as nações ${ }^{60 . "}$

\subsection{ORIGENS E ANTECEDENTES}

Guerra e Paz. Estes dois conceitos certamente foram os norteadores para a fundação das Relações Internacionais enquanto disciplina acadêmica nos idos de 1919, na University College of Wales, em Aberystwyth. Entender as origens da guerra e evitar que um novo conflito de grandes proporções atingisse a humanidade após a tragédia de 1914 assombravam não apenas pesquisadores mas também todos aqueles interessados em política internacional. A fundação da Liga das Nações em 1919 e o desenvolvimento da noção de Segurança Coletiva, a idéia de que todos os membros da sociedade internacional devem se engajar em uma ação conjunta para prevenir e repelir agressores (BELLAMY ET AL, 2004), deixara claro que, em assuntos de guerra e paz, todos os Estados tinham uma função a cumprir.

Ainda que os vinte anos de crise, conforme feliz descrição de E.H. Carr (2002), e a eclosão de um novo conflito internacional de grandes proporções tenham colocado em xeque a capacidade de organizar a ação coletiva em âmbito internacional, uma vez mais a sociedade internacional sentiu-se na necessidade de procurar mecanismos que dirimissem as possibilidades de guerras. Das cinzas de uma Europa novamente destruída surgiu uma nova organização internacional, a Organização das Nações Unidas (ONU), cuja missão, formalmente assumida em seu preâmbulo, seria a de preservar as gerações vindouras do flagelo da guerra. Ao entrar em vigor em

${ }^{60} \mathrm{BUSH}, 1990$ 
24 de outubro de 1945 a Carta das Nações Unidas salientava que, em assuntos relativos à guerra e paz, os Estados membros proporcionavam à emergente instituição três mecanismos para a consecução de seus objetivos. Segundo Barnett e Finnemore (2004), o primeiro mecanismo seria a disponibilidade das forças armadas dos países para a manutenção da paz internacional. O segundo mecanismo seria a capacidade da ONU em empreender medidas militares urgentes e instruía os membros a designarem contingentes aéreos para ações internacionais conjuntas que tivessem a capacidade de impor a determinação da instituição. Por fim, temos a instauração do Military Staff Committe, cuja missão seria assessorar o Conselho de Segurança em assuntos militares, incluindo a direção estratégica das forças armadas à disposição do Secretariado.

Assim, conforme a argumentação de Kennedy (2006), a ONU herdou características de sua antecessora ao mesmo tempo em que representou um grande avanço nas funções outrora exercidas pela Liga das Nações, englobando temas como resolução de conflitos, direitos humanos ou mesmo assuntos econômicos. Todavia, ainda segundo Kennedy (2006: xiv):

"Como a organização mundial foi criada por Estados membros, os quais se comportam como acionistas de uma corporação, ela pode funcionar efetivamente somente quando recebe o suporte dos governos nacionais, principalmente das grandes potências. As nações podem ignorar o organismo internacional, como fez a URSS na década de 1950 e os EUA em 2003, mas isto sempre acarreta um custo. De outro lado, a organização não pode perseguir seus objetivos se um dos grandes poderes - um dos cinco países com direito de veto - se opuserem. Esta tensão entre soberania e internacionalismo é inerente, persistente e inevitável."

A tensão acima descrita tornou-se realidade com a conformação de uma nova distribuição de poder caracterizada por dois pólos antagônicos que impediria que a organização desenvolvesse em sua plenitude todas as suas funções delineadas. Ainda que os capítulos VI e VII da Carta da ONU propusessem quais os meios para a manutenção da paz e segurança 
internacional ${ }^{61}$, de 1945 a 1990 , por exemplo, o direito de veto foi usado 238 vezes (BELLAMY ET AL, 2004) pelos membros permanentes do Conselho de Segurança, evidenciando o quão inoperante se encontrava a organização, resultado da divisão do mundo em esferas de influência e do antagonismo entre EUA e URSS. Três acontecimentos marcantes durante as décadas de 1950 e 1960, no entanto, pareciam dar ensejo ao desenvolvimento das chamadas Operações de Paz.

No início da década de 1950 temos a eclosão da Guerra da Coréia. Em lados opostos estão EUA e Inglaterra, apoiando a Coréia do Sul enquanto que, no extremo oposto, encontramos China e URSS, aliados à Coréia do Norte ${ }^{62}$. Depois de diversas tentativas de derrubar o governo do sul, a Coréia do Norte decidiu atacar Seul, tomando a capital do país. A ONU condenou a ação e, em 15 de julho de 1950, autorizou uma intervenção norteamericana na península. Para muitos, a ação da ONU indicava a capacidade da organização em incitar a ação coletiva entre os Estados membros e evidenciava um papel relevante para o organismo nas questões de segurança internacional. Todavia, um fator deveras importante deve ser acrescentado à equação: após a Revolução Chinesa de 1949 e o não-reconhecimento da ONU do governo de Mao Zedong, a URSS decide boicotar o Conselho de Segurança, o que culminou na autorização para a operação na Coréia. Ainda assim, Bellamy et al (2004) argumentam que esta iniciativa já demonstrava a capacidade da ONU em organizar as Operações de Paz.

Um segundo momento importante é aquele oriundo da Crise de Suez, em 1956. Em meados da década de 1950, a maior parte dos países árabes tornou-se independente, embora em alguns deles ainda houvesse bases estrangeiras. A crescente polarização entre os blocos ocidentalcapitalista e oriental-socialista afetava o posicionamento dos Estados árabes. Conforme aponta Demant (2004: 105):

${ }^{61}$ O capítulo VI, em seu artigo 33 (1) afirma que os meios pacíficos para a resolução de conflitos incluiriam negociação, mediação, conciliação, arbitragem, resoluções jurídicas, entre outros. O capítulo VII, por sua vez, tratam dos meios coercitivos para a manutenção da paz e segurança. Seus artigos 41 e 42 provêm os meios militares e não militares (sanções econômicas, por exemplo) à escolha do Conselho de Segurança.

${ }^{62}$ A Coréia é dividida pelo Paralelo 38 , linha imaginária que se encontra a $38^{\circ}$ graus da linha do Equador. Em 1948, o paralelo foi formalmente estabelecido como fronteira entre a Coréia do Sul e Coréia do Norte. No entanto, a divisão entre as Coréias é datada do final da Segunda Guerra Mundial, resultante de um acordo entre Washington e Moscou. 
"Nos anos 1950 e 1960 a Guerra Fria teve efeitos tanto internos quanto regionais, e dividiu o mundo árabe em dois blocos antagônicos de Estados. Os chamados conservadores, tais como a Arábia Saudita, os sultanatos e emirados peninsulares, além da Jordânia e do Marrocos, entre outros, constituíam em geral monarquias sob forte influência ocidental - agora, mais precisamente dos EUA após a retirada britânica e francesa. Por outro lado, houve uma série de regimes ditos progressistas, originários das revoluções antiocidentais. Foi o caso do Egito, Síria, Iraque, Argélia e Líbia, alinhados à URSS, onde se estabeleceram orientações panarabistas e 'socialistas'. Tais governos tentaram um desenvolvimento estatal, mas os resultados dessas 'ditaduras de desenvolvimento' foram desapontadores."

Quiçá a emergência de Gamal Abdul Nasser no Egito tenha sido aonde o ideal pan-arabista tenha se desenvolvido mais fortemente. Progressista, Nasser ambicionava uma política de desenvolvimento econômico sem sacrificar o ideal de justiça social. Destarte, para financiar seu projeto de irrigação e tendo em mente a negação norte-americana em prover assistência financeira para a empreitada (HOURANI, 1994), Nasser nacionalizou o Canal de Suez, resultando na criação de uma aliança entre França, Inglaterra e Israel e deflagrando a Guerra de Suez, na qual o Egito foi derrotado, além de ver a Península do Sinai ocupada por Israel.

Os acontecimentos acima descritos colocaram vários dilemas para a comunidade internacional. Ambas as superpotências eram contrárias à invasão: enquanto a URSS enxergava uma tentativa desesperada e anacrônica dos ex-poderes coloniais de manterem algum status no Terceiro Mundo, os EUA execraram seus três aliados por terem perpetrado tal ato ilegítimo sem seu conhecimento. Com o Conselho de Segurança travado, ainda que dessa vez as duas superpotências estivessem de acordo, as discussões sobre o tema foram para a Assembléia Geral e o Secretariado ficou responsável por achar alguma saída para o entrave. Segundo Barnett e Finnemore (2004: 126):

"As conversas prévias à invenção do Peacekeeping ocorreram entre o Secretário-Geral Dag Hammarskjöld e o embaixador canadense 
Lester Pearson. Hammarskjöld estava propenso à idéia de um maior papel para a ONU. Foi persuadido quando percebeu que a crise proporcionava uma oportunidade ímpar para a ONU mostrar sua relevância aos Estados membros num assunto crítico e que os países apoiavam a idéia. Após consultas com os Estados envolvidos, Hammarskjöld anunciou a criação de uma força neutra que substituiria a Inglaterra e a França e se colocaria entre Egito e Israel."

Assim sendo, foi possível a aprovação e o envio da United Nations Emergency Force para a fronteira entre Egito e Israel. Todavia, o mandato salientava que a missão não deveria se envolver na política doméstica do Egito, além de não poder recorrer a meios militares, a não ser em casos se legítima defesa.

Por fim, o último evento marcante foi a operação da ONU no Congo, em 1960. Em 30 de junho de 1960, após diversas demandas pela independência, o governo belga aquiesceu e outorgou a sua outrora colônia a condição de Estado soberano. Entretanto, poucos dias antes da independência, soldados congoleses se amotinaram, além de atacarem civis brancos, pilhando as cidades e estuprando diversas mulheres. Mesmo após a independência o motim continuou, levando o novo país a um estado de caos, ameaçando o governo eleito comandado pelo primeiro ministro Patrick Lumumba e pelo presidente Joseph Kasavubu. Em agosto de 1960, as recentes instituições sociais, políticas e econômicas do país estavam paralisadas. A província de Katanga, rica na extração de pedras preciosas e mineirais, sob a liderança de Moise Tshombe, declarou independência do restante do país ameaçando toda a cadeia de exportações congolesa. Bruxelas, num ato unilateral, aprovou o envio de tropas para sua ex-colônia numa tentativa de proteger os belgas que ainda se encontravam no país. De acordo com Dobbins et al (2005: 07):

"Em resposta, o primeiro-ministro Lumumba requisitou que a ONU enviasse tropas para restaurar a paz e expulsar os agressores belgas. O Secretário-Geral Hammarskjöld apoiou a requisição e garantiu uma resolução do Conselho de Segurança autorizando o envio de tropas, a United Nations Operation in the Congo, para 
restaurar a lei e a ordem e promover estabilidade econômica e política. A Bélgica concordou em retirar suas tropas mas somente se elas fossem substituídas pelas da ONU."

Os acontecimentos supracitados proporcionaram à ONU a oportunidade para realizar o que se convencionou designar como Operações de $\mathrm{Paz}^{63}$. Em seus primórdios, as Operações de Paz, cerceadas pelas idiossincrasias e tergiversações de um sistema bipolar, tinham como princípios normativos a tríade consentimento, neutralidade e imparcialidade: as tropas deveriam ser enviadas com o consentimento das partes envolvidas; deveriam ser imparciais e não beneficiar nenhum dos lados em questão; e, por fim, deveriam estar levemente armados e só poderiam utilizar meios coercitivos em casos de legítima defesa. Segundo palavras do então Secretário-Geral Dag Hammarskjöld (apud BARNETT e FINNEMORE, 2004: 127):

\begin{abstract}
"As Operações de Paz devem ser separadas e distintas das atividades exercidas pelas autoridades nacionais e precisam limitar sua atuação para os aspectos externos da situação política em questão ou a ONU corre o risco de se envolver em diferenças com as autoridades locais ou com o público ou mesmo com conflitos internos cuja repercussão seria extremamente prejudicial para a efetividade da operação."
\end{abstract}

Entre 1945 e 1987, a ONU conseguiu implementar, segundo o cômputo de Bellamy et al (2004), 14 Operações de $\mathrm{Paz}^{64}$, nas quais as tropas

\footnotetext{
${ }^{63}$ Como mostraremos mais adiante, as operações de paz da ONU apresentam subdivisões importantes. Assim sendo, doravante optamos por deixar as grafias no original em inglês uma vez que ainda não temos correlatos consagrados no português.

${ }^{64}$ As missões do período foram as seguintes: (1) UN Special Commission on the Balkans (1947-51), para investigar interferências externas na guerra civil grega; (2) UN Truce Supervision Organisation (1948-hoje), missão para monitorar os termos do armistício no Oriente Médio; (3) UN Military Observer Group in Índia and Pakistan (1949-hoje), missão enviada para monitor o cessar-fogo entre Índia e Paquistão; (4) UN Force in Korea (1950-53), enviada para findar com o conflito coreano; (5) UN Emergency Force I (1956-57), para solucionar a crise de Suez; (6) UN Observation Group in Lebanon (1958), para monitorar o movimento de armas e tropas no Líbano; (7) UN Operation in the Congo (1960-64), cuja missão era restaurar a ordem no país; (8) UN Temporary Executive Authority (1962-63), objetivando administrar Nova Guiné antes da transferência de soberania para a Indonésia; (9) UN Yemen Observation Mission (1963-64), para monitorar o movimento de tropas da Arábia Saudita para o Yemen; (10) UN Force in Cyprus (1964-hoje), manutenção da ordem antes da invasão turca de 1974 e o patrulhamento da fronteira após tal fato; (11) UN Índia-Pakistan Observer Mission (1965-66), objetivando monitorar o cessar-fogo entre as partes; (12) UN
} 
raramente eram enviadas no decorrer do conflito e cujos mandatos, na sua maioria, autorizavam o monitoramento de um existente acordo de paz, ajudando os Estados a cumprirem seus compromissos políticos, ou mesmo a manutenção de um cessar-fogo entre as partes. Este tipo de atuação e a importância dada à tríade desenvolvida pelo Secretariado neste período devem-se sobretudo à conjuntura específica do período de Guerra Fria. Num momento histórico marcado pelas disputas político-ideológicas entre EUA e URSS, juntamente com a predominância das idéias realistas não apenas na academia como também nos alto-escalões governamentais, o conceito de segurança internacional ${ }^{65}$ apresentava uma referência defensiva pois, conforme Villa e Reis (2006), comportava um significado instrumental referido a todos os mecanismos e modalidades organizacionais e funcionais do Estado destinados à defesa da integridade territorial e de sua autonomia externa. Mutatis mutandis, sem nenhuma autoridade supranacional a quem recorrer, garantir a segurança seria uma das - senão a principal - função dos Estados nas relações internacionais, relegando às organizações internacionais um papel deveras marginal neste sentido.

Todavia, como já salientado em seção anterior, o final da Guerra Fria foi um momento ímpar para a política internacional não apenas por evidenciar a falência inesperada de uma das potências do período, mas também por provocar mudanças substanciais em muitos temas nevrálgicos envolvendo as relações internacionais. Com o desaparecimento das fronteiras delineadas em Yalta e Postdam e com a supressão do bloco comunista, a segurança internacional, outrora extremamente influenciada pela geografia criada durante os anos de bipolaridade, passou por uma importante inflexão. Conforme esmiuçado por Villa e Reis (2006: 20):

"O único consenso que parece existir é que a questão da segurança internacional dificilmente pode ser apresentada nos mesmos termos da Guerra Fria, e necessita incorporar novas dimensões. Essas

Emergency Force II (1974-79), atuando como tampão entre Israel e Egito no Sinai; (13) UN Disengagement Observer Force (1974-hoje), monitorando a separação das forças israelenses e sírias nas Colinas de Gola; e (14) UN Ínterim Force in Lebanon (1978-hoje), atuando como tampão entre Israel e o Líbano.

${ }^{65}$ Para facilitar a compreensão, convencionamos diferenciar Segurança Internacional, a área de estudos de segurança na disciplina de Relações Internacionais, de seu objeto de estudo, a segurança internacional, pela utilização de caixa alta no primeiro caso. 
dimensões enfatizam duas componentes: mudanças na natureza das relações de poder (incorporação de novos atores e processos capazes de desestabilizar o sistema internacional por meios outros que não os meios político-militares convencionais) e o impacto da distribuição de poder na configuração do sistema internacional, especialmente na relação entre balança de poder e segurança internacional".

Não obstante, é ainda durante o período da Guerra Fria, principalmente durante as décadas de 1950 e 1960, que notamos a ascensão da Resolução de Conflitos (Conflict Resolution) enquanto campo de estudos, iniciado principalmente devido ao desenvolvimento das armas nucleares e da intensificação da competição entre as superpotências, cujas reverberações ameaçavam a sobrevivência da humanidade. Conforme Miall et al (2005: 03):

"Um grupo de pioneiros de diferentes disciplinas enxergaram o valor de estudar conflito como um fenômeno comum, com propriedades semelhantes ainda que ocorresse nas relações internacionais, política doméstica, relações industriais, comunidades, famílias ou mesmo entre indivíduos. Eles enxergaram o potencial para a aplicação de abordagens que estavam se desenvolvendo nas relações industriais e parâmetros de mediações para conflitos em geral, incluindo conflitos civis e internacionais."

Ademais, já na década de 1970, eventos como as discussões acerca de uma Nova Ordem Econômica Internacional, as crises energéticas oriundas dos choques do petróleo de 1973 e 1978, além da realização da Conferência das Nações Unidas sobre Meio Ambiente em 1972, apontavam a emergência de uma gama de temas até então secundários nas relações internacionais, mas que afetavam os interesses de todos os Estados. No entanto, o final da Détente e a rebipolarização, decorrente da ascensão de Ronald Reagan à presidência dos EUA, impediram discussões pormenorizadas sobre tais fatos.

Devido à insuficiência analítica das escolas tradicionais para darem conta destes novos processos, uma gama variada de novas abordagens ganharam espaço no debate envolvendo segurança internacional. Em um 
artigo especulativo (1991a), conforme adjetivação do próprio autor, Barry Buzan, um dos principais expoentes da Escola de Copenhague, tentava prognosticar quais seriam os novos padrões de segurança global para o século XXI e destaca a importância que o meio-ambiente e identidades comunais teriam na agenda de segurança ${ }^{66}$. Da mesma forma, Villa (1999) distingue três campos que foram englobados e que acabaram se tornando variáveis importantes nessa temática, quais sejam, a segurança econômica, a segurança ecológica e a segurança societal ${ }^{67}$.

Essas novas nomenclaturas se coadunam com o fenômeno da expansão da agenda de segurança. Segundo Sheehan (2004), essa ampliação é caracterizada (1) pela aplicação do conceito de segurança a outros campos, não ficando restrito ao campo militar; e (2) pela idéia de que os temas a serem securitizados devem ser tratados não apenas em níveis estatais, mas também se levando em consideração os indivíduos e o sistema internacional ${ }^{68}$. A redefinição no conceito de segurança é bem sintetizada por Villa (1999: 164), ao afirmar que:

"A mudança não se dá na natureza ontológica de risco: a segurança, qualquer que seja a sua manifestação, continua existindo sempre sob a forma de risco; no entanto, o que vem mudando na segurança é o conteúdo de natureza preponderante no período da Guerra Fria, baseado em relações materiais de poder estratégico-militares. Esse deslocamento se dá no sentido de uma noção de risco ampliada e com efeitos para todas as unidades políticas".

\footnotetext{
${ }^{66}$ Segundo Buzan (1991b), o campo de segurança pode ser dividido em cinco setores. Além das dimensões econômicas, ecológicas e societais já citadas no texto, agregam-se ao quadro o setor militar, relacionado às capacidades ofensivas e defensivas dos Estados e a percepção das intenções de terceiros e o setor político, preocupado com a estabilidade organizacional dos Estados e seus sistemas de governo.

${ }^{67}$ A primeira seria entendida enquanto ausência ou prevenção de ameaças a um mínimo de bem-estar material dos cidadãos de um país. Por sua vez, a segurança ecológica seria ausência de ameaças ao bem-estar dos cidadãos de uma unidade territorial e de outros países, indo além do aspecto econômico, englobando a saúde física e mental dos indivíduos assim como os bens ambientais. Por fim, a definição de segurança societal aparece no texto acima citado de Buzan e sugere ausência de ameaças aos padrões de identidade comunais e culturais nas sociedades nacionais.

${ }^{68} \mathrm{O}$ debate sobre segurança internacional é um dos mais profícuos dentro das Relações Internacionais. Para maiores detalhes sobre a Escola de Copenhague, sugere-se WAEVER et al (1998) e TANNO (2003). Para abordagens pós-positivistas, as quais salientam a importância de estruturas de conhecimento compartido para explicar as percepções de ameaça à segurança dos Estados, sugere-se BOOTH (2004). Por fim, uma revisão bibliográfica abrangente sobre segurança encontra-se em VILLA e REIS (2006)
} 
É dentro desta nova conjuntura que surge o conceito de Segurança Humana, cuja repercussão será importante para o entendimento dos Estados Falidos e das operações de Nation-Building. Grosso modo, ainda que definições distintas pululem em diversas publicações, todas procuram enfatizar o bem-estar da população civil. De acordo com o Relatório sobre Desenvolvimento Humano do Programa das Nações Unidas para 0 Desenvolvimento (apud PARIS, 2001: 89):

"O conceito de segurança foi durante muito tempo interpretado estreitamente: ora segurança do território frente à agressão externa, ora proteção do interesse nacional em política externa, ora a segurança global frente ameaças como holocausto nuclear. Esquecidas foram as preocupações legítimas vis-à-vis a população comum, as quais procuram segurança em seu cotidiano. (...) Segurança Humana possui dois aspectos primordiais. Primeiramente, segurança em relação à ameaças crônicas, como fome, doenças e repressão. Em segundo lugar, proteção em relação à repentinas e perigosas interrupções no cotidiano das pessoas seja em seus lares, trabalhos ou comunidades". 69

Dentre as definições arroladas por Paris (2001), encontramos o conceito promovido pelo governo japonês, o qual assevera que Segurança Humana cobre todas as variáveis que ameaçam a sobrevivência, o cotidiano e a dignidade das pessoas - tais como degradação ambiental, violação dos direitos humanos, entre outros - e procura criar medidas para confrontar estas ameaças. Tentando restringir a abrangência do termo (mas sem lograr êxito) o governo do Canadá salienta a proteção contra ameaças que impeçam que a população goze de seus direitos e de suas vidas (apud PARIS, 2001: 90).

Se o conceito de segurança se transforma, também notamos transformações importantes no conceito de paz. Segundo Johan Galtung (1990), quiçá o principal expoente do início do desenvolvimento da Resolução

${ }^{69}$ Os autores do relatório, procurando delimitar tão ampla definição, afirmam que o conceito encerra sete elementos principais: (1) segurança econômica (proteção frente a pobreza); (2) segurança alimentar (acesso à alimentos); (3) segurança para a saúde (acesso ao sistema de saúde); (4) segurança ambiental (proteção frente aos perigos ambientais); (5) segurança pessoal (proteção física contra atos como tortura, guerra, entre outros); (6) segurança comunal (sobrevivência dos valores culturais de determinada população); e (7) segurança política (gozo dos direitos políticos e cíveis). 
de Conflitos enquanto campo de estudos, devemos discernir entre três tipos de violência. Primeiramente, teríamos a violência direta, caracterizada pelo assassinato de indivíduos. Em segundo lugar, temos a violência estrutural, cuja melhor representação seria a morte das pessoas devido à pobreza e, por fim, a violência cultural, mutatis mutandi, tudo aquilo que nos impede de enxergar tais fatos ou que procuram justificar tais ações. Findamos com a violência direta ao mudarmos o comportamento do conflito (trazendo os contendores armados para a mesa de negociação, por exemplo); a violência estrutural extingue-se quando são removidas as contradições e injustiças da sociedade e a violência cultural termina quando ocorrem mudanças nas atitudes dos atores. Assim sendo, Galtung desenvolve os conceitos de paz negativa, caracterizada pela cessação da violência direta, e paz positiva, consubstanciada na superação das violências estruturais e culturais.

As novas nomenclaturas outorgadas e os debates suscitados na área de Segurança Internacional foram assaz influenciados por um fenômeno que iria caracterizar o período pós-Segunda Guerra Mundial mas que iria se acentuar principalmente após o final da Guerra Fria: um declínio no número de conflitos interestatais e um considerável aumento nos embates intraestatais. Esta nova conjuntura foi bastante distinta daquela em que se iniciaram os estudos sobre Resolução de Conflitos, cuja principal característica eram certames entre Estados com características similares (exércitos organizados, por exemplo). Os Conflitos Simétricos, conforme terminologia de Miall et al (2005), principalmente após o final da Guerra Fria, dão lugar para os Conflitos Assimétricos, entre atores com capacidades diferentes, sejam eles um Estado e uma facção rebelde, nos quais a população civil é uma das partes mais afetadas. No entender de Kaldor (1999) e Holsti (1996), deparamo-nos com as Novas Guerras ou Guerras de Terceiro Tipo. Diferentemente das guerras tradicionais, as quais eram caracterizadas pela possibilidade de se distinguir melhor o que é da alçada do Estado e o que não é; pela possibilidade de se diferenciar o que ocorre dentro e o que ocorre fora de determinado território; e pela diferença entre civis e militares (KALDOR, 1999: 20), os novos confrontos apresentam traços distintos.

Holsti argumenta que, para precisarmos os tipos de conflito, devemos ter como critérios (1) o motivo da guerra; (2) o papel dos civis durante 
a guerra; e (3) as instituições da guerra (1996: 27). Enquanto as guerras tradicionais apresentavam as características supracitadas, os novos conflitos não têm objetivos geopolíticos ou mesmo ideológicos; a força motriz está calcada em uma identidade particular, seja ela um clã ou mesmo uma religião. Se outrora os embates eram caracterizados por forças militares que objetivavam ocupar determinado território, hoje o objetivo é controlar a população, incutindo-Ihes o medo e se livrando daqueles que não possuem a mesma identidade (KALDOR, 1999). Segundo Holsti (1996: 36-37):

\begin{abstract}
"As manifestações simbólicas da transformação da guerra são claras: em guerras de terceiro tipo, não existem fronts, campanhas, bases, uniformes, publicidade para forjar honra, point d'appui, e tampouco respeito pelos limites territoriais dos Estados. Não há uma lista de estratégias e táticas. Inovação, surpresa e imprevisibilidade são necessidades e virtudes. Os fracos devem confiar na astúcia, e frequentemente no crime, para levantar fundos para os bombardeios, assassinatos e massacres. Prisioneiros são usados como reféns para se extrair ganhos políticos; o terrorismo é usado para fazer publicidade, não para derrotar um exército. A distinção entre $o$ Estado, as Forças Armadas e a sociedade, característica das guerras institucionalizadas, se dissolvem nesta guerra das pessoas".
\end{abstract}

Os novos tipos de conflito, correndo paralelamente com 0 crescente reconhecimento da importância dos direitos humanos na política internacional, principalmente após a assinatura da Carta das Nações Unidas (1945) e a Declaração Universal dos Direitos Humanos (1948), culminaram em elaborações como a de Michael Walzer (2003: xvi), segundo o qual não é exagero dizer que o maior perigo enfrentado pela maior parte das pessoas no mundo atual provém de seus próprios Estados; e que o principal dilema da política internacional é saber se as pessoas em perigo devem ser resgatadas por forças militares de fora. Em favor dos direitos humanos, a sociedade internacional deve intervir nos conflitos em que abusos generalizados à vida das pessoas estiverem em andamento ${ }^{70}$.

\footnotetext{
70 Para maiores detalhes sobre o debate envolvendo o papel dos Direitos Humanos nas relações internacionais, REIS (2006). Sobre intervenções humanitárias, WALZER (2003) e HOLZGREFE e KEOHANE (2003).
} 
Estes desdobramentos proporcionaram debates envolvendo não apenas situações em que a sociedade internacional teria o direito de atuar ou mesmo quais as características dessas atuações; houve ainda uma discussão importante envolvendo o próprio caráter da soberania, marco basilar das relações internacionais. Segundo definições clássicas, aqui exemplificadas por Bull (2002), os Estados usufruem de uma soberania interna vis-à-vis seu território e população, ou seja, supremacia frente a qualquer outra fonte de autoridade dentro de suas fronteiras; e soberania externa, a independência frente a outros países. Contudo, na conjuntura acima delineada, envolvendo violação de direitos humanos e Estados Falidos, diversas foram as vozes que advogaram uma redefinição deste conceito. Zartman (1995b:267) propunha que a soberania precisava ser repensada como responsabilidade, não como uma cobertura para a tirania. Por outro lado, Evans e Sahnoun (2002:102) afirmam que:

\begin{abstract}
"Até mesmo os mais fervorosos apoiadores da soberania estatal admitirão que nenhum Estado tem poder ilimitado para fazer o que quiser para a sua população. Hoje é reconhecida a responsabilidade dual da soberania: externamente, o respeito à soberania dos demais; internamente, o respeito à dignidade e aos direitos básicos de toda a população dentro do Estado".
\end{abstract}

Toda essa conjuntura da década de 1990 resultou em uma tripla transformação nas Operações de Paz. Segundo Bellamy et al (2004), no período compreendido entre 1988 e 1993, temos primeiramente uma transformação quantitativa, ou seja, a ONU passa a empreender mais operações do que nos 40 anos anteriores ${ }^{71}$. Em segundo lugar, ocorre uma transformação qualitativa, visto que a ONU começa a empreender operações mais complexas do que apenas monitorar cessar-fogos, agregando a tais empreitadas ajuda humanitária e econômica, entre outras variáveis. Finalmente, ocorre uma transformação normativa, a partir do momento em que grande parte dos Estados passa a apoiar a promoção de normas e valores nas missões, principalmente preceitos como o da paz democrática, liberalização

\footnotetext{
${ }^{71}$ Durante estes 6 anos, foram criadas 20 novas Operações de Paz, sem contar as que ainda estavam em andamento.
} 
comercial e o respeito aos direitos humanos. Ainda segundo Bellamy et al (2004), estas transformações também foram iniciadas porque (1) o Conselho de Segurança tornara-se mais proativo após a dissolução da URSS e (2) muitos Estados ficaram cada vez mais interessados em participar das missões, porquanto estas proporcionavam visibilidade internacional, o chamado efeito CNN.

O primeiro documento oficial sobre o tema é o relatório do Secretário-Geral Boutros-Boutros Ghali intitulado An Agenda for Peace e que versava sobre as principais demandas da Nova Ordem Internacional e quais as respostas que a organização poderia proporcionar. Num documento em que convivem a expansão da agenda de segurança e a idéia de que "a pedra basilar deste trabalho é e deve ser o Estado (GHALI, 1992: 04)", o SecretárioGeral afirmava que a maior parte das crises de segurança eram de cunho doméstico e não mais interestatal, o que demandava um novo tipo de engajamento. Logo, Ghali apresenta uma tipologia das Operações de Paz, abaixo caracterizadas:

1. Preventive diplomacy: é a ação levada a cabo para impedir a erupção de conflitos entre as partes além de evitar que se espalhe para os países vizinhos ${ }^{72}$;

2. Peacemaking: é a tentativa de se resolver um conflito em andamento, trazendo as partes envolvidas para a negociação principalmente fazendo uso de meios pacíficos, principalmente os descritos no Capítulo VI da Carta da ONU;

3. Peacekeeping: é o envio de tropas da ONU com o consentimento das partes envolvidas para se findar com um conflito em andamento;

4. Post-conflict Peace-Building: é a ação desenvolvida com o objetivo de identificar e apoiar estruturas que irão fortalecer e solidificar a paz para evitar um retorno aos conflitos. Segundo Ghali (1992), enquanto Preventive Diplomacy são as tentativas de

\footnotetext{
${ }^{72}$ Aqui, as ações são empreendidas antes de o conflito surgir e se caracterizam, na maioria das vezes, em tentativas de se trazerem os contendores para a mesa de negociações.
} 
se evitar a eclosão de uma crise, Post-conflict Peace-Building são as ações empreendidas para se evitar recorrências.

Ainda que este seja considerado o documento pioneiro sobre Operações de Paz, muitos autores consideram outros tipos de ações, com nomenclaturas distintas e mesmo com funções distintas. Consoante o argumento de Doyle e Sambanis (2000), nos defrontaríamos com 4 tipos de empreitadas:

1. Missões de Monitoramento ou Observação: é um arranjo interino usado em conflitos violentos com o consentimento do governo do país, objetivando monitorar uma trégua e ajudar nas negociações de paz por meio da presença de observadores civis e militares;

2. Peacekeeping Tradicional: envolve 0 envio de unidades militares e oficiais civis para facilitar um acordo negociado para o conflito. É calcado no consentimento das partes (normalmente dos dois países beligerantes), além de estabelecer e policiar uma zona tampão e auxiliar na desmobilização e no desarmamento das forças militares;

3. Peacekeeping Multidimensional: é também baseado no consentimento e é formatado para implementar um amplo acordo de paz negociado. Inclui uma mistura de estratégias para construir uma paz auto-sustentável, utilizando desde as forças tradicionais de peacekeeping até estratégias multidimensionais de expansão de capacidades (reconstrução econômica, por exemplo) e transformação institucional (reforma da polícia, do exército, entre outros). São empreendidas principalmente após o final da Guerra Fria;

4. Peace Enforcement: é a intervenção militar, usualmente multilateral, autorizada sob o capítulo VII da Carta das Nações Unidas, objetivando impor a ordem pública pela força com ou sem o consentimento do governo do país em questão. 
Bellamy et al (2004: 05), analisando pormenorizadamente 0 processo de transformação das Operações de $\mathrm{Paz}$, desenvolvem 5 nomenclaturas, que ganham bastante relevo na área de Segurança Internacional. Segundo os autores, teríamos:

1. Peacekeeping tradicional: são as ações realizadas entre um cessar-fogo entre Estados e a conclusão de um armistício. São as operações predominantes do período compreendido entre 19451987;

2. Managing Transition: são levadas a cabo após tanto o cessarfogo quanto o armistício e ambicionam facilitar a implementação do acordo de paz;

3. Wider Peacekeeping: são operações que objetivam implementar as mesmas metas do Peacekeeping tradicional agregando uma gama extra de tarefas, além de serem realizadas, na maioria das vezes, durante $\mathrm{o}$ andamento de um conflito e dentro dos Estados, e não entre os Estados;

4. Peace-Enforcement: objetivam impor as decisões do Conselho de Segurança sobre as partes envolvidas, sejam elas dois Estados beligerantes ou mesmo apenas um Estado em conflito civil;

5. Peace-suport operations: ambicionam estabelecer sociedades democráticas liberais em Estados dilacerados por conflitos. Combinam força militar com componentes civis, sejam eles administrativos e/ou humanitários.

Conquanto a euforia e o otimismo fossem grandes e, no plano retórico, o apoio às operações fosse praticamente consensual, a tensão entre soberania e internacionalismo exposta por Kennedy ainda afligia a ONU. Se o impasse de outrora era resultado do sistema bipolar, agora, a falta de comprometimento político dos Estados membros; as dificuldades de financiamento das missões as quais padeciam de um melhor equacionamento entre os meios e os fins ambicionados; a ainda nascente e pouco desenvolvida capacidade institucional para gerenciar uma empreitada que envolvia tarefas 
muito além do envio de contingentes militares; e a inexperiência dos funcionários neste novo tipo de missões assim como a inexistência de uma memória institucional sobre as operações passadas, comprometeram sobremaneira as Operações de Paz. Por conseguinte, a partir de 1993 surgem os primeiros grandes fracassos, cuja repercussão iria comprometer e diminuir ainda mais o apoio às operações. A situação na Somália, em 1991, é o maior marco nesse sentido.

Com a queda do regime de Siad Barre em 1991 e a ascensão de diversos competidores pelo poder central, a Somália entra em uma guerra civil que paralisaria todo o país, dividindo-o em áreas controladas pelos chamados Senhores da Guerra (Warlords) ${ }^{73}$. Para piorar a situação, concomitantemente aos embates, uma forte seca assolava o país, transformando a situação em um desastre humanitário de grandes proporções. Destarte, em abril de 1992 foi autorizado o envio de uma missão humanitária para o país, sob o comando da ONU, cujo mandato outorgado pelo Conselho de Segurança explicitava que as tropas deveriam monitorar o cessar-fogo em Mogadishu, proporcionar segurança e proteção para o contingente e equipamento e escoltar as entregas humanitárias.

Não obstante, a violência contínua no país, que resultou na morte de soldados paquistaneses do contingente da ONU, culmina em uma nova resolução do Conselho de Segurança, autorizando uma missão norteamericana $^{74}$ no país em dezembro de 1992. O novo mandato afirmava que o escopo da missão era garantir a entrega da ajuda humanitária no país e assistir na instalação de um novo governo democrático, mas os ataques das milícias somalis e a morte de 18 soldados norte-americanos precipitaram a retirada das tropas do país e o fracasso da missão.

O ocaso na Somália levou a uma reavaliação no apoio às Operações de Paz. Segundo Barnett e Finnemore (2004), novas diretrizes foram delineadas para a execução das operações. Dessa forma, as missões deveriam ser autorizadas (1) quando houvesse uma ameaça real à paz e

\footnotetext{
${ }^{73}$ Segundo Giustozzi (2003), Senhor da Guerra é um tipo particular de dominante, cujas características essenciais são sua independência de qualquer autoridade superior e seu controle de um exército privado.

${ }^{74}$ As missões de paz da ONU podem ser lideradas pela organização, quando soldados de diversos países formam o contingente ou autorizadas pela ONU, quando um país assume o comando de uma missão.
} 
segurança; (2) com o auxílio de organizações regionais; (3) com um cessarfogo entre as partes assim como o comprometimento com um processo de paz; (4) com um objetivo político claro e explícito e (5) um mandato precisamente formulado; e, por fim, (6) com a garantia de que o contingente civil e militar estaria seguro. Até mesmo Boutros-Boutros Ghali, outrora fervoroso apoiador das Operações de Paz, tornara-se mais cético ao afirmar que a ONU não pode impor a paz; seu papel é mantê-la. Esta deve ser a mentalidade da ONU (apud BARNETT e FINNEMORE, 2004: 133).

Uma maior seletividade nos casos e um retorno à tríade consentimento, neutralidade e imparcialidade dos anos da Guerra Fria faria com que casos de emergência humanitária fossem relegados, uma vez que o comprometimento dos Estados tendia a ser menor, em detrimento de situações em que a possibilidade de sucesso fosse maior, o que aumentaria a confiança na capacidade da instituição. A situação em Ruanda sofreu com esta conjuntura. Composto por uma maioria Hutu ( $85 \%$ da população) e uma minoria Tutsi (14\%), o país entrara em uma crise econômica no final da década de 1980, devido sobretudo às secas e à queda no preço do café. Uma combinação entre declínio econômico, liberalização política e ressentimento entre as etnias (os Tutsis durante parte da história do país tiveram o controle do governo, o que mudou apenas após a descolonização das décadas de 1950 e 1960) fizeram com que os Hutus, temendo perderem novamente os privilégios adquiridos com a independência, organizassem o genocídio que, em 100 dias, resultou na morte de 800.000 pessoas. Ainda que o Conselho de Segurança tivesse autorizado o envio da United Nations Assistance Mission for Rwanda em 05 de outubro de 1993, as tropas, mal equipadas e com um mandato que salientava a neutralidade, não conseguiram impedir 0 massacre $^{75}$.

Com o propósito de realizar uma avaliação sobre as Operações de Paz e indicar prognósticos para a ação da ONU, realizou-se em 2000 o

\footnotetext{
${ }^{75}$ Numa abordagem com insights construtivistas, Barnett e Finnemore (2004) salientam a força das idéias que guiaram as Operações de Paz após o ocaso somali, assim como o papel de destaque do Secretariado em Ruanda. Segundo os autores, o medo de um novo fracasso que comprometesse o papel da ONU em assuntos de segurança internacional culminou num fortalecimento das idéias de imparcialidade, neutralidade e consentimento e que guiariam o Secretariado para lidar com o caso de Ruanda. Portanto, nesta análise, o foco é desviado do Conselho de Segurança e recai sobre o Secretariado.
} 
Painel sobre as Operações de Paz da ONU, cujo resultado culmina no famoso Brahimi Report. Liderado por Lakhdar Brahimi, o relatório faz um diagnóstico preciso da conjuntura das Operações de Paz:

"Não deveria ter causado nenhuma surpresa que algumas das operações da década passada tenham sido difíceis de serem realizadas: elas tendiam a serem enviadas aonde os conflitos não tinham resultado em vitória para nenhum dos lados, aonde impasses militares, pressão internacional ou ambos tivessem produzido uma trégua, mas nenhum comprometimento sério com o fim dos embates. As operações da ONU, portanto, foram enviadas não em situações de pós-conflito, mas almejavam criá-las. Em situações tão complexas, peacekeepers trabalham para manter um ambiente local seguro, enquanto os peacebuilders trabalham para que este ambiente seja auto-sustentável. Somente um ambiente como este oferece uma possibilidade de saída rápida para as tropas, transformando peacekeepers e peacebuilders parceiros inseparáveis (BRAHIMI, 2000: viii-ix)."

No bojo do relatório encontramos diversas recomendações para as futuras missões, dentre as quais se destacam um maior engajamento das tropas enviadas, relativizando a tríade consentimento, imparcialidade e neutralidade, uma melhor integração entre os elementos militares e civis das operações, apoio político dos países, rápido envio das tropas e uma estratégia de Peace-Building ${ }^{76}$. Ainda que a credibilidade da ONU e das Operações de Paz estivesse chamuscada, a partir de 1999 o Conselho de Segurança autorizou 4 novas operações: no Timor Leste, na República Democrática do Congo, em Serra Leoa e em Kosovo.

\footnotetext{
${ }^{76}$ Brahimi (2000) também apresenta a sua tipologia com relação às Operações de Paz. Segundo o autor, teríamos Importante frisar este último detalhe porquanto Brahimi também apresenta a sua tipologia das Operações de Paz: Peacemaking: lida com conflitos em andamento, procurando criar uma trégua por meio da diplomacia e mediação; Peacekeeping: é a missão tradicional da ONU, envolvendo meios militares para o monitoramento de cessarfogos, mas que no decorrer de sua história incorporou outros elementos, militares ou não, para criar paz após os conflitos civis; Peace-Building: são as estratégias implementadas para construir uma paz que seja mais do que a mera ausência do conflito armado. Envolve desde reintegração de ex-combatentes, passando pelo treinamento de uma polícia local e atingindo até a construção de estruturas democráticas de governo.
} 
Consoante o argumento de Bellamy et al (2004), seis fatores tiveram grande peso para este revigoramento. Primeiramente, muitos países ficaram receosos vis-à-vis as repercussões de crises humanitárias em sua vizinhança, especialmente os desenvolvimentos em Kosovo (no centro da Europa) e Timor Leste (próximo à Austrália). Em segundo lugar, muitos países e organismos internacionais assumiram responsabilidades na criação, organização e comando das operações, como exemplificam o caso australiano no Timor Leste e o da OTAN em Kosovo. Em terceiro lugar, o renascimento das Operações de Paz na África se deveu, sobretudo, aos ativismos de países como Nigéria e África do Sul e à criação de iniciativas como a African Crisis Response Iniciative e o African Peacekeeping Training. Quarto, temos o envolvimento de outros organismos em questões humanitárias, como o Banco Mundial, PNUD e FMI. Em quinto lugar, uma nova tendência acentuou-se no Conselho de Segurança: as missões eram, em sua grande maioria, autorizadas e não lideradas pela ONU, possibilitando que países e organizações regionais colocassem seus soldados em missão sob sua própria liderança. Por fim, a criação de órgãos que avaliavam os erros e acertos de missões passadas possibilitou uma melhor avaliação das conjunturas, procurando adequar os meios aos fins almejados. Todavia, conforme bem salientado por Bellamy et al (2004: 92):

"Uma combinação de fatores, como proximidade geográfica, avaliação das operações passadas e o desenvolvimento de novos conceitos e práticas de peacekeeping induziram um revigoramento das operações até o final da década de 1990, ainda que não seja tão significante quanto a primeira transformação. Se excluídas as operações no Timor Leste e em Kosovo, o aumento das missões foi marginal e houve um retorno aos tipos tradicionais de operações em áreas em que os países ocidentais não assumiram um papel central." 


\subsection{NATION-BUILDING: O QUE É E PARA QUE}

SERVE?

Na seção anterior objetivamos mostrar a evolução das Operações de Paz, desde a fundação da ONU até o final da Guerra Fria. Tal percurso histórico se fez necessário para salientar como as primeiras missões, cujo objetivo era o monitoramento de cessar-fogos entre Estados, se transformaram e adquiriram um caráter mais abrangente - e por que não invasivo -, culminando em operações mais complexas, as quais ambicionavam criar a paz no interior de Estados. Ademais, conforme muito bem salientado por Tschirgi (2004), Nation-Building corresponderia à uma combinação entre Peacekeeping e Peacebuilding, conforme definições criadas pela $\mathrm{ONU}$, por meio dos relatórios de Ghali (1992) e Brahimi (2000). Além desses, não há nenhum documento oficial utilizando o termo como uma nova nomenclatura para Operações de paz. Tendo-se em mente estas transformações, podemos, ao menos, tentar encontrar respostas para as questões que abrem esta seção.

A combinação entre Estados Falidos e grupos terroristas, cuja associação entre a Al-Qaeda e o governo do Talibã no Afeganistão seria o caso paradigmático para demonstrar os problemas oriundos do ocaso estatal, levaram muitos analistas e policymakers a afirmarem que a melhor solução para esta situação seriam as chamadas Operações de Nation-Building ${ }^{77}$ (DOBBINS ET AL, 2003; FUKUYAMA, 2005; BUSH, 2002). No entanto, o que seriam estas Reconstruções de Estado? Seriam elas diferentes das operações de Post-Conflict Peace-Building, propostas por Ghali em 1992, e das operações de Peace-Building, vaticinadas por Brahimi em 2000?

\footnotetext{
77 Antes de avançarmos, cabe fazer uma distinção importante, muito bem apontada por Fukuyama (2007a). Muitas vezes os termos Nation-Building e State-Building são usados como se fossem sinônimos. Não obstante, Nation-Building, conforme sua utilização na Europa, estaria mais relacionado com a idéia de construção da Nação, envolvendo a criação de símbolos e valores. State-Building, por sua vez, seria a construção das instituições políticas ou mesmo aquelas designadas para promover desenvolvimento econômico. Os trabalhos desenvolvidos pela Rand Corporation (DOBBINS ET AL, 2003; DOBBINS ET AL, 2005; DOBBINS ET AL 2007), no entanto, utilizam Nation-Building como se tivesse a mesma significação que State-Building e, devido à popularidade alcançada pelos estudos (Fukuyama, em 2005, publicou livro intitulado State-Building: Governance and World Order inte 21st Century e, na publicação de 2007 utiliza a expressão Nation-Building), o termo ficou consagrado. Doravante, quando nos referirmos à Nation-Building, estaremos utilizando a idéia desenvolvida pela Rand Corporation.
} 
Encontrar uma definição unânime e coesa sobre Nation-Building é uma tarefa deveras árdua devido às distintas caracterizações que pululam nas publicações sobre o tema. Em 2003, no lançamento de America's Role in Nation-Building: from Germany to Iraq, compêndio sobre as operações de Nation-Building dos EUA, a definição utilizada por James Dobbins (2003: 01) era a seguinte: Nation-Building é o uso da força armada após o fim de um conflito para auxiliar uma transição duradoura para a democracia. Todavia, na publicação de 2007, intitulada The Beginner's Guide to Nation-Building, a equipe da Rand Corporation ${ }^{78}$ apresenta a seguinte definição: Nation-Building envolve o uso da força armada como parte de um esforço para promover reformas políticas e econômicas, com o objetivo de transformar sociedades saídas de conflitos em sociedades em paz consigo mesmas e com seus vizinhos $^{79}$.

O problema acima evidenciado não é exclusividade das publicações da Rand Corporation. Na coletânea de artigos editada por Francis Fukuyama intitulada Nation-Building: Beyond Afghanistan and Iraq (2007), notamos que os diversos autores envolvidos na discussão (inclusive o já citado James Dobbins) não comungam de uma única caracterização do termo. Fukuyama (2007a: 4-5) argumenta que:

\begin{abstract}
"Nation-Building envolve dois diferentes tipos de atividades, reconstrução e desenvolvimento. Reconstrução se refere à restauração das sociedades destruídas pelos conflitos. Desenvolvimento, por sua vez, refere-se à criação de novas instituições e a promoção de crescimento econômico sustentável,
\end{abstract}

\footnotetext{
${ }^{78}$ A Rand Corporation é um think tank criado em 1946 cujo principal cliente é a Força Aérea dos EUA. Ayerbe (2006) afirma que pelo seu Conselho Diretor passaram importantes funcionários da atual administração republicana, em especial Condolezza Rice, atual Secretária de Estado, e Donald Rumsfeld, ex-Secretário de Defesa. Para maiores detalhes sobre o papel dos think tanks na política externa dos EUA, sugere-se TEIXEIRA (2007).

79 O porquê da mudança na definição, nem James Dobbins nem nenhum de seus colaboradores nos explica. Todavia, podemos tentar levantar algumas hipóteses. Nos estudos elaborados até 2003, uma das justificativas para as operações de Nation-Building era a de que os EUA já haviam realizado tal empreitada, exemplificados pelos casos da Alemanha e do Japão no pós Segunda Guerra Mundial. O sucesso em reconstruir estes países demonstrava, segundo Dobbins (2003), que a democracia era passível de ser implantada alhures por potências externas, que sociedades podiam ser encorajadas a se transformarem e que grandes transformações podiam durar. Contudo, de 2003 até 2007, os reveses no Iraque e no Afeganistão deixaram claro que a transferência democrática não era tarefa tão fácil, além de ser extremamente questionável, o que pode ter influenciado na definição utilizada pelos autores.
} 
eventos que transformam a sociedade em algo que até então ela não tinha sido."

Minxin Pei, Samia Amin e Seth Gertz (2007) assim como Minxin Pei e Sarah Kasper (2003), argumentam que, para distinguirmos NationBuilding de intervenções militares, devemos ter em mente três critérios. Primeiramente, o objetivo primordial de qualquer operação de Nation-Building é a mudança de regime ou a sustentação do regime que estaria à beira do colapso. Em segundo lugar, destaca-se o grande número de tropas utilizadas nas operações de Nation-Building, principalmente naquelas desempenhadas pelos EUA. Por fim, a utilização de componentes militares e civis na administração política dos países em questão seria, quiçá, o maior diferencial do Nation-Building. Logo, a criação de um regime democrático não é condição sine qua non para a caracterização de uma operação de Nation-Building e a lista de operações realizadas pelos EUA e apresentadas por Pei, Amin e Gertz (2007) é diferente daquela utilizada pela Rand Corporation, envolvendo intervenções desde 1900. Por sua vez, o Banco Mundial utiliza a expressão State-Building e a caracteriza enquanto a reconstrução de um governo central capaz de (1) manter um sistema de segurança em todo o país, (2) uma administração pública efetiva e (3) um orçamento sustentável para os investimentos necessários do país (BANCO MUNDIAL, 2005).

Além dos supracitados, outra leva de autores procura analisar as chamadas operações de Nation-Building. Amitai Etzioni (2004), ao realizar uma revisão bibliográfica sobre o tema, salienta que a expressão "Nation-Building" geralmente é usada para descrever três tarefas diferentes, porém relacionadas: unificação de grupos étnicos, democratização e reconstrução econômica. Ainda segundo seu raciocínio:

"Em sua acepção original, Nation-Building era frequentemente identificado com a unificação de grupos étnicos dentro de um Estado, o que é melhor entendido como 'construção da comunidade'. (...) Nation-Building significa tanto a formação e o estabelecimento de um novo Estado enquanto unidade política quanto o processo de criação de graus viáveis de unidade, adaptação, êxito e um senso de identidade nacional entre a população. Outra visão, contudo, 
identifica Nation-Building como melhoras em governança: criar meios efetivos de governança, implementar o Estado de Direito, combater a corrupção, instalar a democracia e garantir a liberdade de expressão. (...)Um terceira visão, por sua vez, salienta a importância da reconstrução econômica. É sugerido que quanto mais economicamente desenvolvido, um Estado pode funcionar melhor."

Essa conexão Nation-Building - reconstrução econômica não é apontada apenas por Etzioni, visto que o próprio Fukuyama (2007a) em sua definição já frisara tal fato. Não obstante, segundo análise de Ekbladh (2007), durante a Guerra Fria, Nation-Building ${ }^{80}$ esteve intrinsecamente ligado aos métodos e estratégias para se atingir desenvolvimento econômico e social. Segundo o autor, após a Segunda Guerra Mundial, estas operações eram vistas como atividades coletivas, ou seja, todos os países deveriam participar e a noção de desenvolvimento e modernização propagada pelos EUA tinha grande aceitação no globo ${ }^{81}$. Assim, a partir das décadas de 1940, 1950 e 1960, impulsionada pela iniciativa norte-americana, Ekbladh (2007) afirma que surgiram órgãos distintos cuja missão seria prover desenvolvimento econômico. A criação do Programa de Assistência Técnica da ONU, que seria o antecessor do Programa das Nações Unidas para o Desenvolvimento (PNUD), e mesmo a US Agency for International Development (USAID) são exemplos desta conexão. Ademais, o processo de descolonização africana e asiática culminara no surgimento de novos Estados no sistema internacional, tornando-os alvos de disputas entre as superpotências além de destinatários das políticas de ajuda externa.

Se desenvolvimento econômico era a panacéia para todos os males durante a Guerra Fria, ao final da Guerra Fria o foco é cambiado. Com o crescente aumento dos conflitos intraestatais durante a década de 1990 e a concomitante evolução das Operações de Paz, Nation-Building, segundo Hippel (1999), que até então significava a construção de governos estáveis,

${ }^{80}$ Durante a Guerra Fria, a acepção de Nation-Building esteve intimamente relacionada ao processo de descolonização, culminando em um conceito relacionado com a construção de uma Nação.

${ }^{81}$ Neste período, ganhou destaque a chamada Teoria da Modernização. Em linhas gerais, esta corrente procurava salientar a relação causal existente entre desenvolvimento econômico e o surgimento de regimes democráticos. Mutatis mutandis, o estágio final da modernização seria o advento da democracia e, assim sendo, seria possível e desejável que os países subdesenvolvidos seguissem o exemplo dos países desenvolvidos. 
que podiam ou não ser democráticos, passou a carregar em seu bojo a idéia de construção de Estados democráticos e estáveis. A estratégia de democratização, no entanto, existia desde a Guerra Fria. Segundo Hippel (1999: 95-96):

“(...) Durante a Guerra Fria, democratização significava mais um meio para combater o avanço comunista do que uma real implementação de reformas democráticas. Somente com o final da Guerra Fria esta exportação democrática ganhou mais vigor, com o objetivo último de garantir a paz e segurança internacional. A promoção da democracia é baseada no pressuposto de que democracias não vão à guerra umas com as outras e que o aumento no número de democracias no mundo significaria, além de encorajar, um mundo mais seguro e pacífico."

Hamre e Sullivan (2002), desfavoráveis ao termo Nation-Building, utilizam o termo Reconstrução Pós-Conflito (Postconflict Reconstruction), definindo-o como o provimento e o fortalecimento não apenas do bem-estar econômico e social, dos meios de governança e o Estado de Direito, mas também outros elementos como justiça e reconciliação, além, é claro, da segurança do país. Por fim, Tschirgi (2004) afirma que Nation-Building envolve operações multidimensionais de paz, incluindo tarefas civis tais como segurança do território, construção dos aparatos militares assim como dos policiais e garantia da entrega da ajuda humanitária além de prover auxilio administrativo para a construção dos novos ministérios do Estado, para a transição democrática e para o crescimento econômico do país.

Das definições acima, ainda que cada uma apresente suas especificidades e problemas, podemos identificar uma linha comum entre as mesmas. Todas elas salientam a construção de instituições políticas democráticas, além de frisarem a importância que o desenvolvimento econômico apresenta para a estabilização dos países. De fato, outros estudos em Ciência Política já apontavam esta vinculação. Przeworski et al (1997), por exemplo, destacam que, para a implantação de um regime democrático, é 
necessário que um país apresente determinado grau de riqueza ${ }^{82}$, crescimento com inflação moderada, desigualdade decrescente, um clima internacional favorável e instituições parlamentares. Ainda que mantenha a vinculação entre democracia e desenvolvimento econômico, o erro crasso das operações de Nation-Building é sua demasiada ênfase na promoção democrática, sem possibilitar os meios necessários para uma mudança efetiva de regime.

É este um dos pontos em que estas operações se diferenciam das Post-Conflict Peace-Building propostas por Boutros-Boutros Ghali e das missões de Peace-Building delineadas por Lakhdar Brahimi ${ }^{83}$. É fato que tanto Ghali quanto Brahimi sublinharam em seus documentos a importância da democracia nas Operações de Paz; no entanto, ambos salientam que as estratégias para uma paz duradoura vão além da realização de eleições. Reintegração dos ex-combatentes, o fortalecimento do Estado de Direito via, por exemplo, a reestruturação da polícia local e reformas dos sistemas penal e judiciário, fortalecimento do respeito aos direitos humanos por meio do monitoramento, educação e investigação de abusos passados são apenas algumas das estratégias sugeridas. Conforme palavras de Brahimi (2000:07):

"Eleições livres e transparentes devem ser vistas como partes de um esforço maior para fortalecer as instituições governamentais. As eleições poderão ser melhor realizadas em um ambiente em que a população que se recupera do conflito aceite a urna em detrimento das armas como um mecanismo apropriado por meio do qual suas visões sobre o governo possam ser representadas. As eleições precisam do apoio de um processo maior de democratização e de construção de uma sociedade civil que inclua governança civil efetiva e uma cultura de respeito aos direitos humanos, para se evitar que uma eleição apenas ratifique uma tirania da maioria ou que o resultado seja derrubado pela força depois da saída das tropas."

82 Os autores afirmam que uma democracia deve durar em média 8,5 anos num país cuja renda per capita esteja abaixo dos US\$1.000 por ano, 16 anos num país em que a renda per capita esteja entre US\$1.000 e US\$2.000, 33 anos com renda estando entre US\$2.000 e US\$4.000 e 100 anos entre US\$4.000 e US\$6.000 (PRZEWORSKI et al, 1997: 116).

${ }^{83}$ Conforme argumentam Bellamy et al (2004), e evidenciando a falta de consenso sobre o tema, State-Building, entendido aqui como a criação das estruturas governamentais, seria uma das quatro tarefas incluídas sob o conceito de Peacebuilding. As demais seriam 0 estabelecimento do Estado de Direito, democratização e reconstrução econômica. 
Em outras palavras, realização de eleições não é sinônimo de um Estado reconstruído. Roland Paris (2004) argumenta que mesmo as operações de Peace-Building da década de 1990 eram guiadas por uma estratégia de liberalização. No âmbito político, liberalização significa democratização, ou seja, a promoção de eleições periódicas, limites constitucionais ao exercício do poder e respeito às liberdades básicas. No âmbito econômico, liberalização está relacionada às reformas pró-mercado, incluindo medidas direcionadas à diminuição da intromissão do Estado na economia, paralelamente o apoio ao aumento do papel dos investidores privados. No entanto, segundo o autor, tal estratégia parece ter impulsionado a tendência para uma nova leva de violência nos países. Segundo Paris (2004: 06):

\begin{abstract}
"Transições dos conflitos civis para democracias de mercado são cheias de contratempos: promover democratização e reformas prómercado possuem o potencial para estimular maiores níveis de competição num momento em que os Estados ainda não estão equipados para conter tais tensões dentro de limites pacíficos. Os peacebuilders da década de 1990 subestimaram os efeitos desestabilizadores do processo de liberalização nas frágeis circunstâncias de países saídos de guerras civis."
\end{abstract}

A crítica de Paris é direcionada para as operações de PeaceBuilding em países caracterizados por guerras civis e empreendidas no período compreendido entre 1989 e $1999^{84}$. Contudo, sua constatação é extremamente válida para as operações de Nation-Building, que muitas vezes pressionam para realização de eleições de forma prematura. Schumpeter (1984) já havia definido democracia enquanto a escolha de lideranças pela competição por votos; incutir esta competição em um ambiente em que os ressentimentos de guerra ainda não foram totalmente superados e no qual as práticas democráticas ainda não estão arraigadas é um experimento que, sem os meios necessários para controlar as tensões, pode redundar num ressurgimento dos conflitos armados. Não estamos querendo questionar a qualidade da

${ }^{84}$ As operações analisadas por Paris (2004) são: Namíbia (1989-1990); Nicarágua (19891992); Angola (1991-1997); Camboja (1991-1993); El Salvador (1991-1995); Moçambique (1992-1994); Libéria (1993-1997); Ruanda (1993-1996); Bósnia (1995-hoje); Croácia (19951998); Guatemala (1997). 
democracia enquanto forma de governo, assim como não o fazem os autores acima citados; o que questionamos é o timing para a realização dos pleitos. Numa resenha publicada em 2003, Dobbins afirmara que o tempo mínimo para a democratização de um país, entendido como a construção de todo o arcabouço eleitoral e a realização dos pleitos é de sete anos; no mesmo ano, na obra America's Role in Nation-Building e nas subseqüentes, o tempo mínimo diminui para cinco anos.

Estes apontamentos de certa forma já antecipam a resposta para a segunda pergunta que abre a esta seção, ou seja, para que serviriam as operações de Nation-Building. Tendo-se em mente as reformulações nos conceitos de segurança internacional e de paz oriundos das novas realidades do sistema internacional, Nation-Building seria uma das ferramentas utilizadas para se alcançar a paz em países destruídos por guerras civis e/ou Estados Falidos. Ademais, no contexto pós Onze de setembro de 2001, Nation-Building, Mudança de Regime (Regime Change) e Estabilização e Reconstrução foram utilizados como a melhor maneira para se lidar com as novas ameaças à paz $\mathrm{e}$ segurança e a maior parte dos arautos destas empreitadas acreditam que mudanças tão substanciais como estas podem ser lideradas por agentes externos.

Neste ponto, Nation-Building se distancia dos diversos tipos de Operações de Paz formulados tanto por Ghali quanto por Brahimi pois, além de destacarem a importância da assistência de outros países, estes frisam que a paz e a segurança não podem ser impostas de fora; devem ser criadas e sustentadas internamente, por meio de estratégias flexíveis e pacientes em consonância com as realidades domésticas. Conforme muito bem apontado por Tschirgi (2004: 17-18):

"A agenda de estabilização pós-Onze de setembro é baseada nos mesmos termos da agenda de Peacebuilding da década de 1990, com um enfoque holístico, de abordagens integradas para evitar o fracasso e o colapso estatal. Todavia, os propagadores desta agenda de estabilização são os interesses de segurança nacional dos atores externos, regionais ou internacionais, dominantes. As intervenções de Peacebuilding da década de 1990, as quais foram motivadas por impulsos humanitários, parecem ter preparado o 
terreno para intervenções externas em Estados soberanos, ainda que as motivações fossem distintas das de hoje".

Nas caracterizações propostas principalmente pelos estudos da Rand Corporation, a transição para a democracia, representada pela realização de eleições, seria o zênite das missões. No entanto, surge aqui mais uma incógnita que merece uma melhor problematização: quais os métodos utilizados para a realização das operações? O que é priorizado na execução de uma missão? As características internas e as demandas do país alvo da operação são levadas em consideração no processo de Nation-Building? Paris (2004) argumenta que as operações de Peace-Building são guiadas por uma estratégia de liberalização que pouco levam em consideração as singularidades dos Estados alvo e acreditamos que as operações de NationBuilding também possuem este traço. Todavia, quais são os meios utilizados para se alcançar esta liberalização?

Fukuyama (2007b) argumenta que as atuais operações de Nation-Building seriam um grande grande-chuva, que envolveriam quatro outros tipos de operações: Peacekeeping; Peace-Enforcement ${ }^{85}$; Post-Conflict Reconstruction; e Desenvolvimento político-econômico de longo prazo. Se a definição do autor salienta a importância da Reconstrução e Desenvolvimento, os principais esforços deveriam ser direcionados para três grandes áreas. Garantir a segurança seria condição sine qua non para uma bem sucedida operação de Nation-Building. Dessa forma, treinar uma nascente polícia civil, desarmar, desmobilizar e reintegrar os ex-combatentes e findar com possíveis resquícios de milícias contrárias à operação seriam os passos primordiais. Restaurar a autoridade política seria a segunda grande tarefa a ser realizada e aqui prevalece a construção de instituições políticas democráticas. Segundo Fukuyama (2007b: 237):

"No mundo contemporâneo, a legitimidade vem primariamente, ainda que não exclusivamente, de eleições democráticas. A realização de eleições, portanto, é crítica para estabelecer uma nova e legítima

${ }^{85}$ A definição de Fukuyama (2007b) para Peacekeeping e Peace-Enforcement é similar às apresentadas até o momento neste trabalho. Para ilustrar a diferença, o autor afirma que enquanto os peacekeepers podem se apresentar como neutros, os peace enforcers não podem visto que devem defender um dos lados. 
ordem, mas as questões de quando, como e em que medida devemse realizar eleições dependem das circunstâncias específicas de cada situação pós-conflito."

Além disso, o desenvolvimento econômico, pelo menos num primeiro momento, continuaria a depender da assistência externa. A execução de projetos humanitários assim como a reconstrução da infra-estrutura do país inclui uma quantidade variável de participantes, desde agências multilaterais (como a ONU, o Banco Mundial e o FMI), passando por agências governamentais (a USAID, por exemplo), chegando até às organizações nãogovernamentais que, muitas vezes, não se comunicam entre si, ocasionando grandes problemas. Um dos principais deles, segundo Fukuyama (2007b), advém do fato de que os doadores externos, ao entrarem com maiores capacidades financeiras, atraem os melhores recursos humanos para a execução de seus projetos, deixando poucos trabalhadores qualificados para trabalharem no governo.

Os objetivos propostos por Fukuyama de certa forma contemplam as tarefas que Dobbins et al (2007: xxiii) apontam como inerentes às operações de Nation-Building. Segundo os autores, o objetivo primário de qualquer Nation-Building é transformar sociedades violentas em pacíficas, não transformar pobres em prósperas ou autoritárias em democráticas ${ }^{86}$. Para tanto, os autores organizaram uma hierarquia de tarefas abaixo listadas:

1. Segurança: peacekeeping, implementação do Estado de Direito e reforma do setor de segurança;

2. Ajuda humanitária: retornos dos refugiados e prevenção de epidemais, fome generalizada e falta de abrigos;

3. Governança: retomada dos serviços públicos e da administração pública;

4. Estabilização econômica: implementação de uma nova moeda e a organização de um marco regulatório para que o comércio local e internacional possa ser restaurado;

\footnotetext{
${ }^{86}$ Há que se destacar que nesta publicação, a ênfase na democratização já não é tão grande quanto nas publicações anteriores.
} 
5. Democratização: criação de partidos políticos, imprensa livre, sociedade civil e a realização de eleições;

6. Desenvolvimento: fomentar o crescimento econômico, reduzir a pobreza e restaurar a infra-estrutura do país ${ }^{87}$.

Mas, e os recursos financeiros e militares para a consecução de tamanha gama de tarefas? Segundo Dobbins et al (2007), as despesas das operações são divididas - ou deveriam ser - entre os países que contribuem com tropas, os doadores internacionais e a comunidade internacional como um todo de acordo com as várias formas de se dividir os ônus. Os custos das operações lideradas pela ONU são divididos entre os países membros, ainda que o Estado que comanda a missão arque com os principais custos. Para medida de comparação, Dobbins et al (2005: xxxvi) afirmam que:

"O custo de uma operação de Nation-Building da ONU tende a parecer bem modesto vis-à-vis às operações dos EUA, as quais são mais complexas e difíceis. No momento, os EUA estão gastando algo em torno de 4,5 bilhões de dólares por mês para financiar sua operação no Iraque. Este mesmo montante é o que é utilizado pela ONU para manter todas as suas 17 operações de peacekeeping durante um ano."

Ademais, Dobbins et al (2005) argumentam que, segundo um estudo do Banco Mundial encabeçado pelos economistas Paul Collier e Anke Hoeffler (2004), as intervenções militares no pós-conflito seriam o meio com a melhor relação custo-efetividade para a estabilização dos países ${ }^{88}$. Embora os autores da pesquisa cheguem a esta conclusão, a forma como a descobrem é complexa e não é completamente apresentada no estudo da Rand Corporation. Como a intervenção militar se torna o meio com melhor relação custo-

\footnotetext{
${ }^{87}$ Hamre e Sullivan (2002) também apresentam pilares semelhantes para uma reconstrução de Estado. Segundo os autores, os quatro pilares das operações são: provimento de segurança; justiça e reconciliação (reforma do setor penal e criminal, polícia civil, entre outros); bem-estar econômico e social (restauração de políticas públicas, tais como saúde e educação); e, por fim, governança e participação (criação de instituições políticas representativas).

${ }^{88}$ Além da intervenção militar, Collier e Hoeffler (2004) analisam também a ajuda externa anterior ao conflito, a transparência no gerenciamento da renda oriunda dos recursos naturais, o rastreamento dos recursos naturais e a ajuda externa pós-conflito como formas de se prevenir a erupção de novos embates.
} 
efetividade é o que fica de fora dos estudos de Dobbins et al $(2005$; 2007) e precisa ser destacado. Consoante o raciocínio de Collier e Hoeffler (2004), numa situação pós-conflito, o risco de um retorno ao conflito armado é tipicamente alto ainda que gradualmente decline se a paz consiga perdurar. Ajudas econômicas tendem a diminuir o risco mas, algumas delas, demoram certo tempo para fazer efeito. Dessa forma, segundo Collier e Hoeffler (2004: 20):

"A maioria dos governos em situações de pós-conflito parecem concluir que um aumento nos gastos militares é um pré-requisito para a paz. Durante as guerras civis, o montante dos gastos militares é o dobro daqueles realizados durante os períodos de paz e, durante a primeira década após o conflito, declina modestamente. Os gastos militares pós-conflito são muito próximos daqueles feitos durante os anos de guerra civil. Devido os altos riscos de um novo conflito, parece lógico que seja necessário um aumento dos gastos militares para se manter a paz."

Destarte, gastos militares altos podem ser lidos pelos contendores do governo central como uma denúncia do acordo de paz. Dessa forma, sumarizando o argumento dos autores, as intervenções militares teriam como efeito precípuo o declínio dos gastos militares por parte do governo do país, evitando este dilema de segurança interno.

Assim como a noção de Estados Falidos, a idéia de NationBuilding possui seus problemas. Não obstante, ainda que as formas correntes de execução desta empreitada apresentem incongruências e lacunas pouco explicadas, apontam para um fato importante: na reconstrução de Estados, a sociedade internacional possui um papel importante, uma vez que um país devastado não possui capacidades suficientes para se auto-reerguer. Enquanto novas alternativas não são colocadas em prática, procuramos verificar como foram levadas adiante as operações de Nation-Building realizadas por seus principais executores: a ONU e os EUA. 


\title{
4. NATION-BUILDING EM PERSPECTIVA COMPARADA
}

Em se tratando de Nation-Building, como mensurar sucesso e fracasso? Minxin Pei e Sara Kasper (2003) argumentam que o sucesso das operações depende de três variáveis. Primeiramente, devemos levar em consideração as características internas do país, uma vez que Nation-Building é uma engenharia política em grande escala. Assim sendo, o quão homogêneo um país é, se serão utilizados a burocracia antiga ou novos órgãos governamentais serão construídos são fatores assaz importantes. Em segundo lugar, os autores argumentam que um alinhamento entre os interesses dos países interventores com os da elite do país-alvo possibilita uma maior chance de sucesso uma vez que o comprometimento de ambas as partes será maior. Por fim, os recursos econômicos devem ser suficientes para levar adiante toda a empreitada. Por outro viés, Dobbins et al (2003; 2005) argumentam que Nation-Building pode ser entendido em termos de Inputs - grosso modo, força militar, recursos financeiros e tempo para a execução da tarefa - e Outputs dentre os quais se destacam número de baixas, mudanças nos números de refugiados e pessoas dispersas internamente, crescimento da renda per capita e democratização. Assim sendo:

\begin{abstract}
"Sucesso em Nation-Building depende da sabedoria com que tais recursos serão usados e da suscetibilidade da sociedade em questão em apoiar as mudanças em andamento. Todavia, sucesso é também em alguma medida dependente da quantidade da presença militar e policial internacional e da assistência econômica, assim como do tempo em que tais recursos são aplicados (DOBBINS ET $A L, 2005: x x i)^{89}$."
\end{abstract}

\footnotetext{
${ }^{89}$ Ao que tudo indica, os estudos da Rand Corporation passaram por um processo de reavaliação. No estudo prévio, sobre as operações dos EUA (DOBBINS ET AL, 2003), o sucesso em uma missão era definido como a habilidade para promover uma transferência duradoura de instituições democráticas. Com definição deveras controversa, é bastante provável que para o volume seguinte, sobre as operações da ONU, os autores tomaram mais cuidado para definir sucesso e fracasso.
} 
Destarte, como os países e as organizações internacionais se organizam para realizar esta tarefa multidimensional é um fator extremamente importante para avaliarmos sucesso e fracasso. Comungamos da opinião de Bensahel (2007), ao afirmar que reforma burocrática pode ser a menos glamourosa medida, mas uma das mais importantes para possibilitar que os atores desenvolvam capacidade para empreender operações de NationBuilding, uma vez que há a demanda de coordenação entre agências governamentais e processos de tomada de decisão. Tendo-se em mente que 0 estudo da Rand Corporation compara o sucesso e fracasso das operações de Nation-Building realizadas tanto por EUA quanto por ONU caso por caso, enveredaremos por uma direção distinta, porém, a nosso ver, deveras importante. Procuraremos comparar como EUA e ONU se organizam para Nation-Building, o que, ao final, nos mostrará porque certas missões tendem ora a fracassar, ora a lograrem êxito.

\subsection{A ONU E NATION-BUILDING}

"Me dêem os meios e poderei fazer mais ${ }^{90 "}$

A despeito da maior ênfase em Nation-Building como ferramenta para se lidar com problemas de segurança internacional após o Onze de setembro de 2001, os estudos da Rand Corporation afirmam que tanto ONU quanto EUA possuem casos anteriores em que uma transição para a democracia fora alcançada alhures. No caso da ONU, a experiência pioneira ocorrera no Congo, logo após a independência do país do jugo belga.

Por que a missão no Congo é o caso paradigmático para a ONU? Conforme salientado em seção anterior, o conflito civil no Congo foi deflagrado logo após a independência do país, momento nevrálgico uma vez que as instituições políticas eram embrionárias e não possuíam apoio dos contendores, além de um alto grau de desconfiança belga sobre o futuro do país. Diferentemente do conceito tradicional de Peacekeeping, limitado pela tríade consentimento, imparcialidade e neutralidade, o mandato da operação

\footnotetext{
${ }^{90}$ General Dallaire, comandante da missão da ONU em Ruanda - UNAMIR, apud BARNETT e FINNEMORE, 2004.
} 
no Congo ${ }^{91}$ outorgava à missão autoridade para restaurar a ordem, assegurar a retirada das tropas belgas e promover estabilidade política e econômica no país (DOBBINS ET AL, 2005). Não obstante, um empreendimento desse porte demandava estruturas que a organização ainda não desenvolvera; assim, boa parte das tarefas foi realizada de maneira ad hoc.

Ademais, outro traço suis generis da Operação das Nações Unidas no Congo (ONUC), caracterizada enquanto Nation-Buiding por Dobbins et al (2005) é o fato de que a democratização nunca fora seu principal objetivo; garantir a descolonização e preservar a integridade territorial do país eram as metas prioritárias. Conforme salientam Dobbins et al (2005: 25):

\begin{abstract}
"A República do Congo era um Estado Falido desde a sua concepção. Seu exército estava amotinado e as demais instituições do país estavam em colapso. A ONU, chamada para restabelecer a segurança, completar o processo de descolonização e manter a integridade territorial do país, respondeu com rapidez e precisão e força. No processo para completar estas tarefas, a ONU encontrouse conduzindo uma completa operação de Peace-Enforcement e a sua primeira, mas não a última, missão de Nation-Building. A ONU obteve êxito e alcançou seus principais objetivos ${ }^{92}$."
\end{abstract}

Todavia, a missão apresentou aspectos positivos e negativos. Primeiramente, ficou comprovado que Nation-Building requer uma mistura de capacidades civis e militares; unidade de comando é fundamental para coordenar todas as tarefas; e o sucesso depende grandemente de uma forte liderança e de grande apoio internacional. Do lado negativo, ficou comprovado que os recursos financeiros e contingentes civis e militares necessários na maioria das vezes excedem o montante disponível; impor a paz é altamente

\footnotetext{
${ }^{91}$ A resolução 161 do Conselho de Segurança da ONU estabelecia: (1) garantir a retirada das tropas belgas do Congo; (2) ajudar o novo governo a garantir lei e ordem; (3) prover assistência técnica; (4) manter a integridade territorial e a independência política do Congo; (5) evitar a ocorrência de uma guerra civil e assegurar a retirada de todas as tropas estrangeiras do Congo. São claras as diferenças vis-à-vis a missão criada depois da Crise de Suez, na qual as tropas da ONU deveriam criar uma zona tampão entre Israel e Egito.

92 Vizentini (2007) questiona os resultados alcançados na operação do Congo. Segundo o autor, após a retirada das tropas da ONU em 1963, Moise Tshombe retornou ao país e foi nomeado primeiro-ministro. Com a ajuda norte-americana, caçou seus adversários os quais almejam criar um governo de esquerda no leste do país. Ademais, em 1965, o coronel Mobutu desfechou um golpe de Estado, assumindo a presidência e mudando o nome do país para Zaire.
} 
custoso e controverso, ainda que bem feito; e desenvolvimento democrático pode conflitar com outras prioridades.

As idiossincrasias do sistema internacional durante a Guerra Fria não incentivaram o desenvolvimento de órgãos dentro da ONU cujo objetivo fosse aumentar a capacidade institucional e operacional para 0 desenvolvimento de novas missões com o mesmo porte. Somente ao final da Guerra Fria é que a ONU é incentivada a repensar o papel das Operações de Paz e a desenvolver organismos para as missões. Ainda que An Agenda for Peace seja o documento seminal sobre o assunto, Boutros-Boutros Ghali procurou chamar a atenção dos Estados membros para a prevenção e resolução de conflitos; incrementar a capacidade institucional da ONU não era o seu objetivo principal. Assim, temos a criação em 1992 de apenas dois órgãos, ambos ligados ao Secretariado: o Departamento de Assuntos Políticos (Department of Political Affairs - DPA), cujas responsabilidades vão desde análise política, Peacemaking e Preventive Diplomacy, Assistência Eleitoral, entre outros, e o Departamento de Operações de Peacekeeping (Department of Peacekeeping Operations - DPKO), cujo objetivo fulcral é planejar e manter diretamente as missões da ONU para que as mesmas possam cumprir seus respectivos mandatos e que, na época de sua fundação, era comandado pelo futuro Secretário-Geral Kofi Annan. 
Organograma do DPA ${ }^{93}$

\section{DEPARTMENT OF POLITICAL AFFAIRS}

Organizational Chart

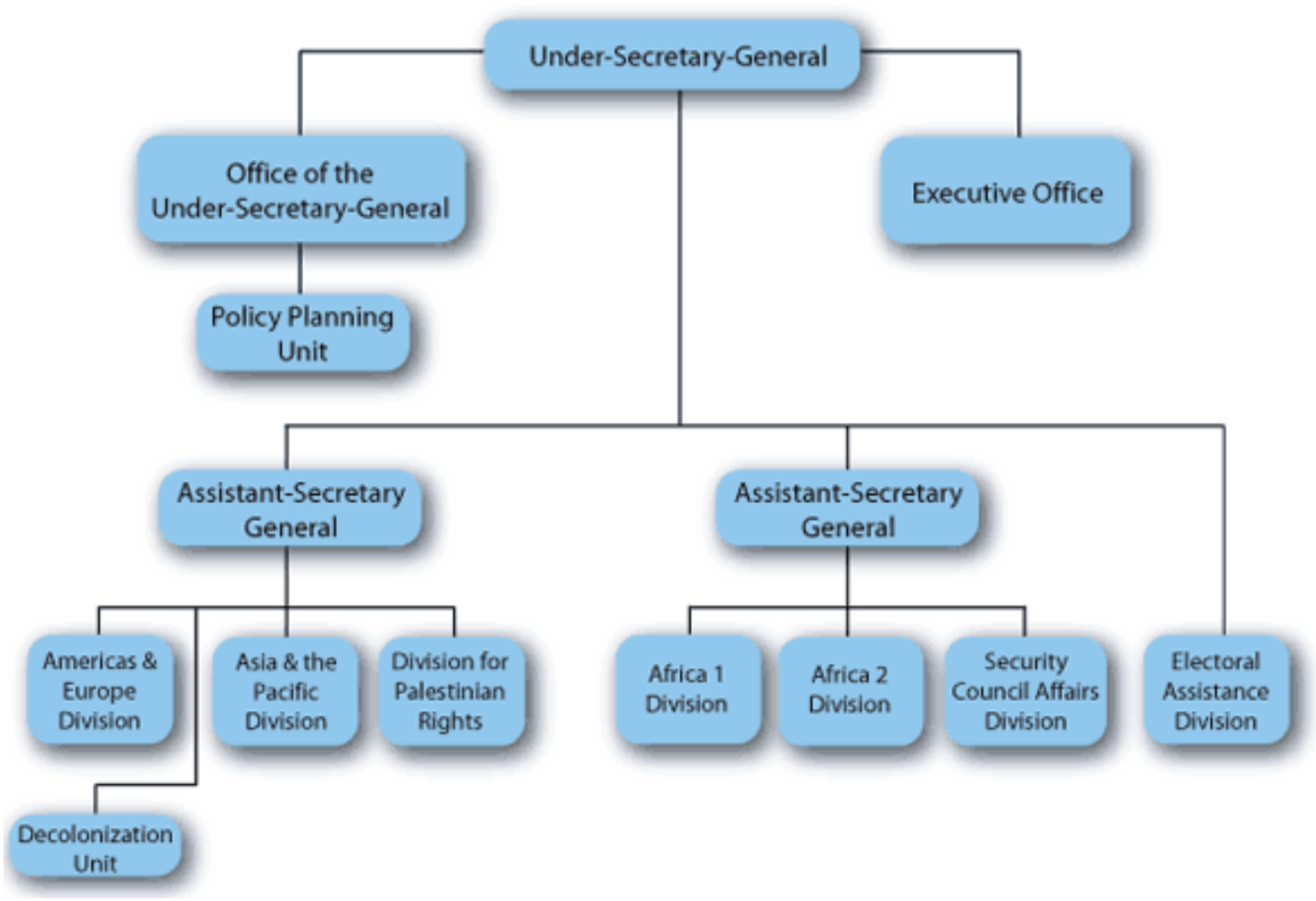

${ }^{93}$ Disponível em www.un.org. Acesso em 23/03/2008. 


\section{Organograma do DPKO ${ }^{94}$}

\section{Department of Peacekeeping Operations}

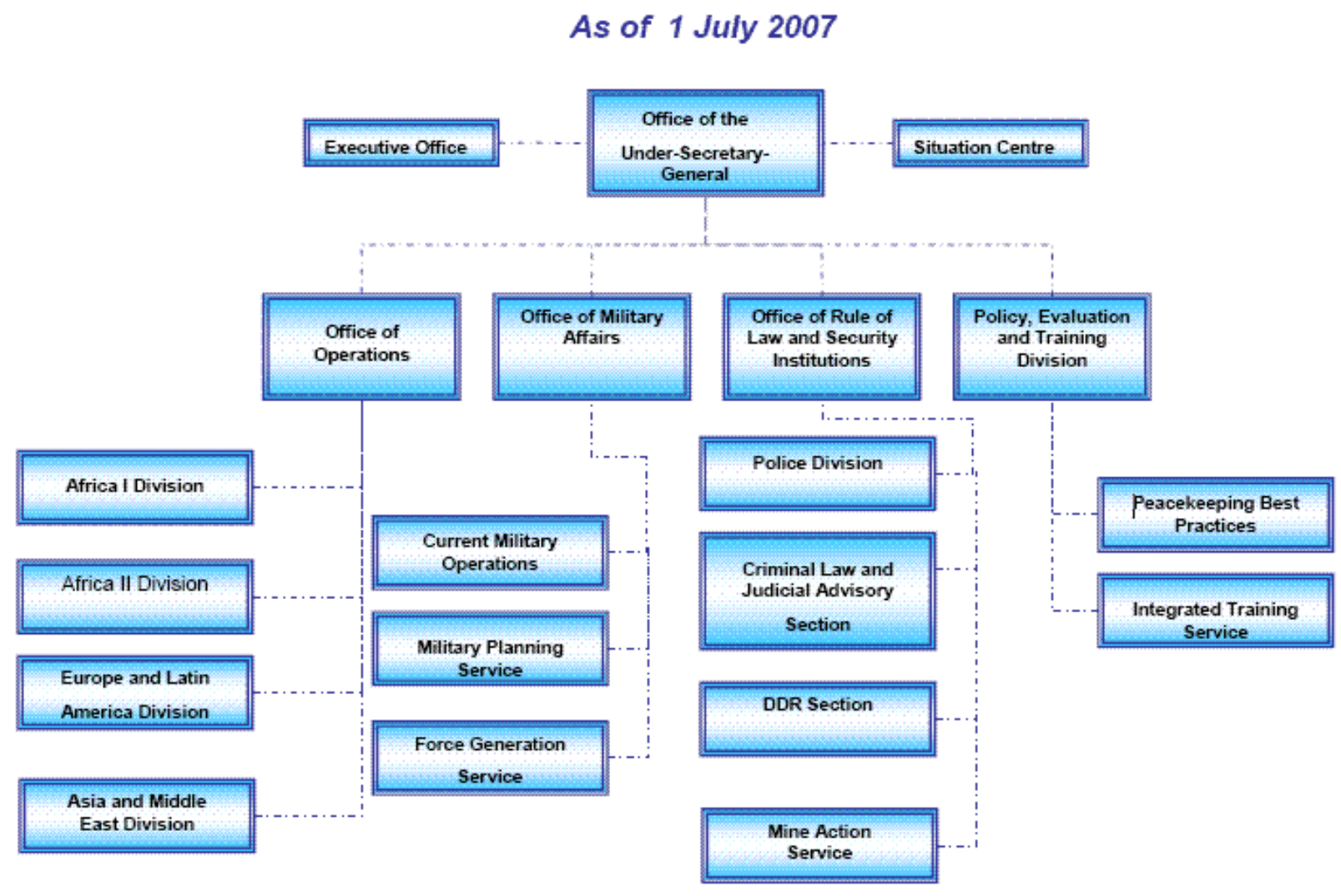

No entanto, conforme já salientado, a expansão quantitativa e qualitativa nas Operações de Paz demandava reformas nas estruturas da organização, assim como uma maior coordenação com agências como o Banco Mundial, FMI e PNUD. Dessa forma, em abril de 1995 temos o estabelecimento dentro do Departamento de Operações de Peacekeeping de uma unidade de Lições Aprendidas (Lessons Learned Unit), cuja ambição era tornar-se o centro para análise dos resultados esperados e obtidos nas Operações de Paz, ainda que a priori fosse pequena e sofresse falta de recursos.

O funcionamento das unidades relacionadas com Operações de Paz, principalmente as mais recentes como a unidade de Lições Aprendidas, conforme apontado por Benner et al (2007), era sustentada por contribuições voluntárias. A partir de 1997, um fundo foi criado para custear novos postos e

${ }^{94}$ Disponível em www.un.org. Acesso em 23/03/2008. 
recursos, financiados pela Fundação Ford e pelos governos da Suécia e Alemanha. Com a chegada de Kofi Annan ao Secretariado-Geral, aumentaram os pedidos para financiamento das Operações de Paz. Contudo, os Estados membros negaram a maior parte, apenas provendo renda extra para novos postos dentro da unidade de Lições Aprendidas. Em 1998, almejando melhorar os serviços e tendo-se em mente os recursos escassos, o DPKO fundiu as unidades de Lições Aprendidas e a também sub-financiada unidade de Análise e Política (Policy and Analysis unit), culminando na unidade de Analise Política e Lições Aprendidas (Policy Analysis and Lessons Learned Unit), com 17 postos financiados por doadores externos.

Caminho similar também foi percorrido pelo Departamento de Assuntos Políticos. Em seu interior foi criada a unidade de Planejamento Político (Policy Planning unit) juntamente com a Equipe de Prevenção de Conflitos (Conflict Prevention Team), ambos objetivando prover o departamento com diretrizes para a ação preventiva. Além disso, Kofi Annan criou o Comitê Executivo para Paz e Segurança (Executive Committe for Peace and Security), encarregado de realizar relatórios sobre assuntos relativos à paz e segurança. Todavia, segundo Benner et al (2007), sem os fundos necessários e se digladiando com os demais órgãos da instituição por recursos escassos, as novas unidades ainda não conseguiram executar em sua integridade as tarefas designadas. O porquê da falta de apoio à ONU por parte dos Estados é um assunto extremamente debatido. Ainda que os neoinstitucionalistas salientem a importância das organizações internacionais para dirimir os altos custos de um sistema internacional anárquico (KEOHANE E NYE, 1989), a tensão inerente entre soberania e internacionalismo é uma constante em sua história ${ }^{95}$. Dessa forma, podemos entender o fracasso das missões na Somália e em Ruanda, situações em que esta tensão não possibilitou maior apoio à ONU.

Todavia, com o Brahimi Report, temos mais uma tentativa de se reavaliar o papel da ONU referente às Operações de Paz. A nova leva de operações no final da década de 1990 salientada em capítulo anterior culminou na necessidade de se procurar saídas para que as capacidades do DPKO não

\footnotetext{
95 Joseph Grieco (1993) argumenta que a possibilidade de cooperação internacional é minada devido à possibilidade de trapaça no sistema internacional, pela preocupação com os ganhos relativos e pela idéia de que os Estados devem manter certo grau de independência para assim protegerem seus interesses.
} 
fossem levadas ao seu limite e uma vez mais ocasionassem redundantes fracassos. O relatório, além de fazer uma revisão sobre as operações anteriores, fez recomendações de cunho burocrático para assim incrementar a estrutura da ONU, destacando-se uma nova unidade para análise estratégica e avaliação das atividades de Peacebuilding dentro do DPA; a introdução da Força Tarefa de Missão Integrada (Integrated Mission Task Force) para avaliar as operações em campo; e a revitalização da unidade de Análise Política e Lições Aprendidas do DPKO. O momento não podia ser mais feliz: com operações como as de Kosovo e do Timor Leste em andamento, as quais possuíam amplo apoio, boa parte dos recursos necessários chegou à ONU e 191 postos foram criados no DPKO. Das propostas citadas, merece destaque a Força Tarefa de Missão Integrada, pois tinha como objetivo coordenar e reunir todos os atores relevantes para as missões na sede do DPKO. Destarte, as reuniões a serem realizadas e os atores envolvidos (não apenas representantes dos países, mas também outras agências da ONU e organizações regionais, por exemplo) já deixavam clara a natureza multidimensional das missões.

Em 23 setembro de 2003, o então Secretário-Geral da ONU Kofi Annan anunciou um Painel sobre Ameaças, Desafios e Mudanças (Threats, Challenges and Change), cuja missão era avaliar as ameaças contemporâneas para a segurança internacional, revisar o funcionamento dos órgãos do ONU e recomendar possíveis mudanças para fortalecer a instituição. O relatório oriundo das discussões notou um traço importante da instituição: não há um organismo no sistema ONU encarregado em lidar com fracasso estatal ou mesmo auxiliar países na transição de guerra para a paz. Para tanto, recomendou-se a criação de uma Comissão de Peacebuilding, o principal órgão para a realização de Nation-Building, conforme apontado por Bensahel (2007). Segundo o relatório intitulado A more secure World (2004: 83-84), resultado do Painel, as funções de tal órgão seriam:

"Identificar países que estão em perigo e podem rumar em direção ao colapso; organizar, em parcerias com o governo nacional, assistência pró ativa para prevenir que este processo continue se desenvolvendo; ajudar no planejamento das transições entre 
Peacebuilding antes e depois do conflito; e, em particular, organizar e manter os esforços da comunidade internacional no Post-Conflict Peacebuilding durante o período que for necessário."

Organograma do Peacebuilding Comission ${ }^{96}$

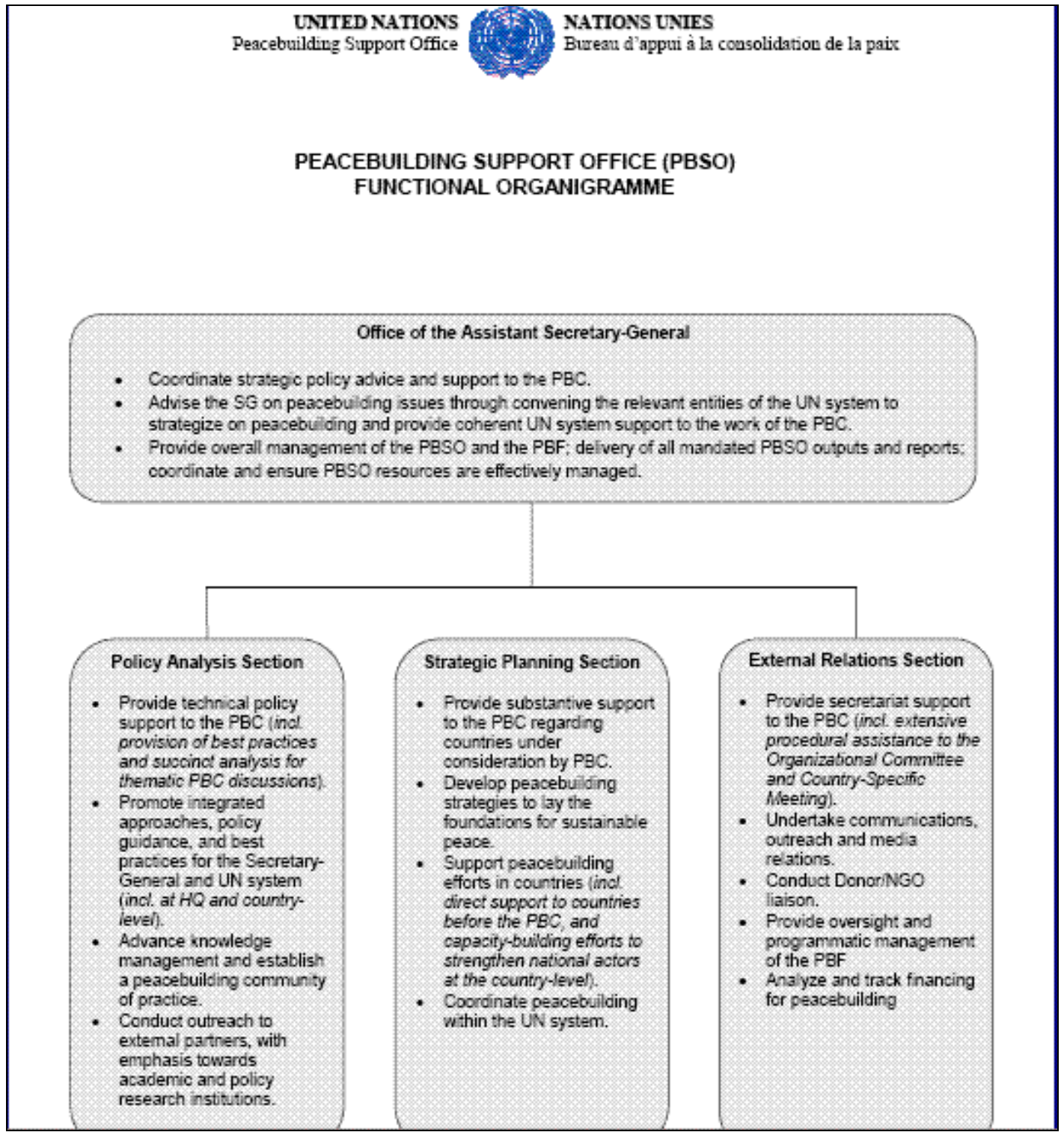

A Comissão de Peacebuilding conta com um Comitê Organizacional, composto por 31 membros servindo mandatos de 2 anos com possibilidade de renovação ${ }^{97}$. Ademais, quando ocorrem as reuniões,

${ }^{96}$ Disponível em www.un.org. Acesso em 23/03/2008.

97 A composição dos membros é feita da seguinte maneira: sete membros do Conselho de Segurança, incluindo os permanentes; sete eleitos pelo Conselho Econômico e Social (Economic and Social Council), os cinco maiores provedores de contingentes militares e civis; e 
representantes dos países em questão e de países vizinhos podem ser chamados, além de organizações regionais e internacionais relevantes, os maiores financiadores das missões e o representante da ONU em campo, entre outros. Inserido dentro da comissão está o Peacebuilding Support Office, cuja missão é coordenar as atividades do PNUD e do DPKO assim como as demais agências relevantes na operação. Por fim, para custear todos estes incrementos, foi criado o Peacebuilding Fund, mantido pelo PNUD e criado para proporcionar um início rápido para as operações enquanto os fundos para os objetivos de médio e longo prazo são levantados. Findada a análise institucional, é necessário um relato, ainda que breve ${ }^{98}$, dos casos de NationBuilding da ONU arrolados pela Rand Corporation e quais os resultados alcançados.

A primeira operação de Nation-Building da ONU nos momentos finais da Guerra Fria foi realizada na Namíbia. Com a assinatura do acordo de paz entre Angola, Cuba e África do Sul em 1988, chegou-se a termo a guerra civil que por 23 anos assolava o país. Sob tutela da África do Sul desde a Primeira Guerra Mundial até 1971, quando a Corte Internacional de Justiça julgou ilegal a presença sul-africana no país, a Namíbia nunca tivera uma experiência consistente com as práticas e instituições democráticas. Assim sendo, a ONU criou por meio da Resolução 435 de 1978 do Conselho de Segurança a United Nations Transition Assistance Group (UNTAG), cujos objetivos eram ajudar nas eleições e garantir a transição de uma condição de ex-colônia para país soberano. Não obstante, as tergiversações da África do Sul e dos Estados Unidos, os quais postergaram o envio das tropas por cerca de uma década devido à presença cubana na vizinha Angola, atrasaram o cronograma. Dessa forma, somente com o acordo de paz de 1988 é que a UNTAG pode cumprir seu mandato.

sete adicionais selecionados pela Assembléia Geral. Os atuais membros são: Angola, Bangladesh, Bélgica, Brasil, Burundi, Chile, China, República Checa, Egito, El Salvador, Fiji, França, Geórgia, Alemanha, Gana, Guiné-Bissau, Índia, Indonésia, Itália, Jamaica, Japão, Luxemburgo, Holanda, Nigéria, Noruega, Paquistão, Rússia, África do Sul, Sri Lanka, Inglaterra e EUA.

${ }^{98}$ Não é nossa intenção refazer os estudos de caso arrolados pela Rand Corporation, visto que o espaço para tanto ultrapassaria o escopo do presente trabalho. Assim, tanto para os casos da ONU como para os casos dos EUA, tencionaremos apenas relatar de forma breve 0 contexto para as reconstruções e os resultados alcançados, segundo Dobbins et al (2003; 2005). 
A missão tinha como diretrizes garantir o acordo de paz, ajudar no retorno dos refugiados, supervisionar eleições nacionais e ajudar no estabelecimento de um governo democrático em um país sem experiência prévia. Ademais, há de se destacar os papéis desempenhados na assistência para a retirada das tropas sul-africanas do país assim como a ajuda para a polícia local na manutenção da lei e da ordem. Segundo Dobbins el al (2005), a operação foi bem sucedida visto que fora bem liderada, possuíra os recursos humanos e financeiros suficientes, garantindo a independência namibiana em 1990. Por fim, ficou claro que um clima internacional favorável e um objetivo bem definido e apoiado por todas as partes são peças fundamentais em Nation-Building.

O segundo caso é o de El Salvador. A assinatura do acordo de paz, patrocinado pelos EUA e pela ONU, entre governo e a Frente Martí de Libertação Nacional (FMLN) em 1992 findou com doze anos de conflito civil ${ }^{99}$. A ONU deveria afiançar um cessar-fogo entre as partes, supervisionar o desarmamento e desmobilização da FMLN, reformar as Forças Armadas do governo, garantir o respeito aos direitos humanos no país e dar assistência para a realização de eleições democráticas. Das lições aprendidas nesta missão, conforme Dobbins et al (2005), destacam-se a importância da participação direta da ONU antes da implementação do acordo de paz, a reintegração dos ex-combatentes no processo político e a reforma da segurança interna, que deve abranger todos os âmbitos do sistema judiciário: polícia, juízes, promotores, assim como as casas de detenção. Todavia, conforme apontado pelo autor, o contingente civil e militar da ONU foi insuficiente e dependeu sobremaneira da colaboração das partes envolvidas no processo político.

Pouco depois da autorização para a missão em El Salvador, a ONU deparou-se com a situação do Camboja, cujas origens nos remetem às décadas de 1960 e 1970. Com a tomada do poder pelo regime do Khmer Rouge, liderado por Pol Pot, iniciou-se uma campanha de coletivização no país

\footnotetext{
${ }^{99}$ A Frente Martí de Libertação Nacional era de corrente marxista-leninista e tinha apoio da URSS. A administração Reagan, conforme aponta Ayerbe (2002), temendo o chamado Efeito Dominó na América Central a partir das mudanças na Nicarágua e Granada e a instabilidade em El Salvador, criou a Iniciativa da Bacia do Caribe, buscando ampliar o comércio e melhorar os investimentos. Além disso, temos uma forte injeção de assistência militar, aportando para El Salvador 700 milhões de dólares no biênio 1981-1983 para treinamento e compra de armas.
} 
o que redundou na morte de cerca de 1,7 milhões de pessoas. Ademais, os embates fronteiriços entre o Camboja e o Vietnã culminaram na invasão vietnamita no país, iniciada em 1978, ocasionando a queda e posterior retirada do Khmer Rouge para as selvas e a ocupação do país por mais de uma década. Somente com o final da Guerra Fria foi possível a criação de um ambiente propício para um acordo de paz, o qual ocorreu em Paris em 1991. O armistício deu à ONU um papel importante no Camboja, outorgando à instituição a responsabilidade de garantir a transição para um governo democrático e administrar o país durante este processo. Esta era uma conjuntura muito mais complexa que o caso de El Salvador: enquanto neste último caso a ONU auxiliava um governo pré-estabelecido, agora não havia sequer governo para ser auxiliado; a instituição deveria governar de fato todo o país.

Tão ambicioso mandato, cujos objetivos deveriam ser alcançados em apenas dois anos, chocou-se com o perene problema da escassez de recursos que perseguem as missões da ONU. Todavia, a despeito dos problemas enfrentados, a organização conseguiu findar com a guerra civil, monitorou a retirada das tropas vietnamitas além de ajudar na recuperação econômica do país. A democratização, objetivo caro nas operações de NationBuilding, contudo, pode ser questionada: a ONU conseguiu organizar eleições mas os resultados foram contestados e nos pleitos seguintes surgiram acusações de fraudes, além de atos de vandalismo e mesmo mortes. Collier e Hoeffler (2004) já apontavam para este dado: em países saídos de guerras civis, as primeiras eleições podem ser consideradas sucesso devido à forte presença estrangeira; no entanto, a partir da segunda, quando a vigilância diminui, a ameaça de perturbações é maior.

Em 1993 teve início a missão da ONU em Moçambique, após a assinatura de um acordo de paz entre o governo e a Resistência Nacional Moçambicana (RENAMO). O armistício deu termo a uma guerra civil que começou logo após a independência do país do jugo português em 1975, colocando em lados opostos um governo apoiado pela URSS e a RENAMO, afiançada pelos governos da então Rodésia do Sul e da África do Sul. Com o final da Guerra Fria e a assinatura do acordo, a ONU foi chamada pelas partes para monitorar a sua implementação e auxiliar na organização de eleições. 
Ademais, dentre os demais desafios podemos destacar o auxílio aos 2 milhões de refugiados e os 3 milhões de dispersados internamente, o desarmamento e a desmobilização dos contendores e a ajuda na reconstrução econômica do país.

Uma das melhores práticas criadas durante a missão em Moçambique foi a desmobilização dos combatentes antes das eleições. Diferentemente de Angola, aonde a ONU enviara uma missão de peacekeeping para monitorar as eleições de 1992, mas deixara de lado a bem armada UNITA, o resultado foi a rejeição dos resultados e o retorno dos combates. Em Moçambique, a desmobilização das partes foi feita antes o que impossibilitou que a RENAMO cogitasse retomar o conflito devido à diminuição do seu contingente. Todavia, o principal problema da missão em Moçambique se deu no âmbito econômico: a renda per capita, segundo Dobbins et al (2005) ainda está em 230 dólares e a transição de uma economia estatal para uma economia de mercado ainda é difícil.

A operação seguinte desenrolou-se na Croácia, entre 1995 e 1998. Em junho de 1991, Eslovênia e Croácia declararam independência da lugoslávia, culminando no início de conflitos armados entre as forças croatas e o exército iugoslavo, o qual era composto em sua maioria por sérvios e possuía apoio de grupos paramilitares croatas de origem sérvia. Em contraste com a situação na Eslovênia, onde houve uma rápida retirada das tropas iugoslavas, na Croácia as forças sérvias ocuparam os territórios de Krajina, Western Slavonia e Eastern Slavonia, territórios caracterizados tanto por maiorias sérvias ou com parcelas substanciais de sérvios.

Primeiramente a ONU enviou a United Nations Protection Force (UNPROFOR), missão de peacekeeping tradicional, com o objetivo de separar os combatentes e criar as condições para um acordo de paz entre as partes. Com o fracasso da missão, a ONU aprovou o envio da United Nations Confidence Restoration Operation for Croatia (UNCRO), a qual também não obteve resultados satisfatórios. Em uma tentativa de se evitar uma guerra de proporções maiores entre Croácia e lugoslávia, França, Alemanha, Rússia, Inglaterra e EUA pressionaram o governo croata e as lideranças sérvias em Eastern Slavonia a assinarem um acordo no qual toda a região de Eastern Slavonia seria integrada à Croácia. Para tanto, a ONU foi chamada para 
administrar Eastern Slavonia durante um período de dois anos, assegurando a transição do domínio sérvio para a Croácia, por meio da United Nations Transitional Authority in Eastern Slavonia (UNTAES).

Podemos entender a missão na Croácia como uma operação de Nation-Building sui generis, visto que a região de Eastern Slavonia seria reintegrada ao território croata, diferentemente dos demais países nos quais garantir a independência era uma das tarefas a serem alcançadas. Dentre as demais tarefas a serem alcançadas estavam a desmilitarização da região, o estabelecimento de uma força policial temporária, facilitar o retorno dos refugiados, monitorar o cumprimento do acordo por parte dos sérvios e croatas, comandar a administração civil e prover os serviços públicos e, por fim, organizar eleições locais. Das missões do pós-Guerra Fria, sejam elas da ONU ou dos EUA, a operação na Croácia foi a mais bem sucedida, pois obteve os recursos necessários para cumprir seu mandato, além de contar com o apoio da maior parte dos países vizinhos e das grandes potências.

A missão seguinte desenrolar-se-ia em Serra Leoa, após a assinatura de um acordo de paz em 1999 entre o governo e a Revolutionary United Front of Sierra Leone (RUF), partes de um conflito que começara em 1991, a partir do momento em que a RUF lançou uma ofensiva da fronteira com a Libéria para tentar derrubar o governo em Freetown. Em outubro de 1999, o Conselho de Segurança autorizou a criação da United Nations Mission in Sierra Leone (UNAMSIL), cujo mandato demandava a supervisão do desarmamento, desmobilização e reintegração das partes em conflito, que continua ativa até os dias de hoje.

Os desafios para a ONU eram grandes. O governo central era fraco e os índices de corrupção altíssimos; as forças rebeldes controlavam mais da metade do país e a sua boa vontade para com o acordo, segundo Dobbins et al (2005), era altamente questionável. Por fim, Serra Leoa passava por uma crise humanitária fortíssima, com parte da população sem os serviços básicos: escolas e hospitais estavam destruídos e ondas de fome e diversos tipos de doença assolavam o país. Num primeiro momento, contando com um contingente mal treinado, mal equipado e despreparado, além do pouco interesse das grandes potências, cujas atenções estavam voltadas para a situação em Kosovo, a operação ainda enfrentou o seqüestro de boa parte do 
seu contingente por parte das forças rebeldes. Com o iminente colapso da missão, a Inglaterra enviou tropas para resgatar os seqüestrados além de treinar um exército local. Os EUA apoiaram a operação, provendo apoio logístico e diplomático, sem contar com os esforços do Secretário-Geral Kofi Annan, o qual procurou formar um consenso sobre a necessidade de se apoiar a missão. Assim, pôde-se levar adiante o desarmamento das forças dissidentes e a organização de eleições.

A última operação de Nation-Building da ONU arrolada pela Rand Corporation foi aquela desenvolvida no Timor Leste a partir de 1999. Após a independência timorense de Portugal em 1975, a ilha foi invadida e anexada pela Indonésia que, a despeito das diversas resoluções do Conselho de Segurança da ONU contrários à anexação, permaneceu no país até 1999. A queda do presidente Suharto e a pressão internacional sobre a Indonésia criaram um clima favorável para a resolução da situação no Timor Leste. Depois de uma série de negociações envolvendo ONU, Indonésia e Portugal, foi organizado um referendo em 05 de agosto de 1999 para decidir sobre a condição do território. Com a vitória dos partidários pró-independência, conflitos emergiram no Timor Leste, apoiados pela Indonésia, desgostosa do resultado. Não obstante, a pressão dos EUA, FMI, Banco Mundial e dos países vizinhos forçou Jacarta a permitir o envio de uma força multinacional liderada pela Austrália para findar com as ondas de violência. Com a restauração da ordem, - Conselho de Segurança autorizou a criação da United Nations Transitional Administration in East Timor (UNTAET), cujo mandato encerrava uma administração interina, a supervisão da reconstrução do país e de sua posterior independência. A missão foi posteriormente substituída pela United Nations Mission Support in East Timor (UNMISET), responsável por levar adiante as tarefas além de incrementar as estruturas institucionais do país, reformando o sistema judiciário e a segurança pública.

A missão no Timor Leste foi bem sucedida, conforme Dobbins et al (2005), visto que contou com um clima internacional favorável, sendo liderada pela Austrália e apoiada pelas grandes potências, obteve os recursos humanos e financeiros necessários para cumprir seu mandato e comungou de uma característica semelhante àquela encontrada na Croácia: o território a ser 
assegurado era relativamente pequeno. Assim sendo, eleições foram realizadas e o processo de reconstrução econômico pode ser levado adiante.

A análise das operações, ainda que breve, salienta alguns traços importantes das operações da ONU. Por ser uma organização internacional, dependente dos seus integrantes, a ONU precisa contar com o apoio de seus principais financiadores e da boa vontade em montar e equipar as operações. As tergiversações dos países membros, principalmente dos membros permanentes do Conselho de Segurança dificultam a operacionalidade da missão. Dessa forma, para que possamos mensurar e entender sucesso e fracasso nos termos colocados por Dobbins et al (2005) de Inputs e Outputs, é assaz importante levarmos em consideração esta conjuntura. Outro traço das missões da ONU é que são menores que as desenvolvidas pelos EUA, quando comparadas em termos de contingente e recursos financeiros, culminando na caracterização de Small Footprint ${ }^{100}$. A missão no Congo, por exemplo, contou com 19.828 pessoas em campo, enquanto a Namíbia teve 4.493 soldados. No entanto, por terem um mandato negociado entre as partes, apresentam um maior grau de legitimidade, o que aumenta as chances de sucesso.

Com o objetivo de possibilitar uma visão comparativa de NationBuilding, ordenar as idéias e prover os elementos necessários para a realização de nosso estudo de caso, o passo seguinte passa a ser a análise das operações empreendidas pelos EUA, seguindo os mesmos moldes: uma visão institucional, uma apresentação das missões e as considerações gerais sobre as mesmas.

${ }^{100}$ De acordo com Dobbins et al (2003), o Small Footprint consiste no envio de contingentes menores para evitar que as missões de paz apresentam um caráter intrusivo para a população local. 


\subsection{OS EUA E NATION-BUILDING}

"Eu não acho que nossas tropas devam ser usadas pelo o que tem sido convencionado chamar Nation-Building. Eu acho que nossas tropas devem ser usadas para lutar e vencer guerras ${ }^{101}$."

Quando voltamos nossas atenções para os EUA, as reconstruções da Alemanha e do Japão são consideradas os casos paradigmáticos de Nation-Building. Destruídos pela guerra, ambos os países receberam aportes substanciais para suas respectivas reestruturações políticas e econômicas. Entretanto, os motivos que deram ensejo para as operações e que possibilitaram os grandes investimentos estavam sobremaneira vinculados aos ditames da Guerra Fria. Segundo Gaddis (2005), Stálin achava que os custos da guerra deveriam ditar a divisão dos louros. Logo, depois de mais de 27 milhões de baixas, a URSS teria por direito não apenas a aquisição dos territórios perdidos durante o conflito, como também anexaria aqueles que ele considerava estarem em sua esfera de influência. Sintetizando, a meta de Stálin não era restaurar o equilíbrio de poder na Europa, mas dominar o continente tão completamente como Hitler quisera (GADDIS, 2005: 13).

Os EUA, conquanto ecos do isolacionismo do pós-Primeira Guerra Mundial ainda fossem ouvidos, sabia da necessidade de se engajar mais ativamente no sistema internacional. E, para tanto, uma das tarefas primordiais seria conter o avanço soviético. Alemanha e Japão, dessa forma, eram entendidos enquanto teatros importantes e demandavam a devida atenção, pois países destruídos com uma população carente dos serviços mais básicos, proporcionavam um contexto atraente para a propagação do comunismo. Para a reconstrução alemã, a principal fonte de financiamento foi o Plano Marshall ${ }^{102}$, que, segundo Gaddis (2005: 30), baseava-se nas seguintes premissas:

\footnotetext{
${ }^{101}$ George W. Bush apud FUKUYAMA, 2007: 01

102 Para o caso japonês, o plano de reestruturação econômica foi baseado no programa desenvolvido pelo banqueiro Joseph Dogde. Segundo Dobbins et al (2003: 50), seu principal objetivo consistia em equilibrar o orçamento, o qual se encontrava em constante déficit. Assim sendo, o plano proibia quaisquer gastos para os quais não houvesse fundos suficientes; impedia que o governo japonês provesse qualquer subsídio a determinados setores; culminou na dispensa de vários funcionários do governo e das indústrias; aumentou os impostos; congelou os preços; aumentou os preços do arroz, transportes e outros bens e serviços subsidiados pelo governo; e, por fim, reduziu os serviços públicos.
} 
“(...) a ameaça mais séria aos interesses ocidentais na Europa não era a perspectiva de uma intervenção militar soviética, mas o perigo de fome, pobreza e desespero levarem os europeus a porem no governo seus próprios comunistas, que então atenderiam obedientemente os desejos de Moscou; que a ajuda econômica americana produziria benefícios psicológicos imediatos e, mais adiante, benefícios materiais que reverteriam aquela tendência; que a URSS não aceitaria essa ajuda e não deixaria seus satélites aceitarem, provocando tensão nas relações com eles; e, finalmente, que os EUA poderiam, então assumir a iniciativa tanto geopolítica quanto moral na Guerra Fria que vinha à tona."

Segundo Dobbins et al (2003), os anos de conflitos destruíram grandemente a infra-estrutura tanto da Alemanha quanto do Japão, este último ainda sofrendo com as conseqüências das bombas atômicas de Hiroshima e Nagasaki. Assim, fazia-se necessário a reconstrução não apenas da infraestrutura básica do país, mas também a construção das novas instituições políticas e econômicas. É nesse ponto que Fukuyama (2007a) questiona as operações na Alemanha e Japão enquanto Nation-Building. Segundo o autor:

"Os EUA e os aliados pouco realizaram em se tratando de reconstruir os Estados: tanto Alemanha quanto Japão possuíam poderosas burocracias que sobreviveram enfraquecidas à guerra, mas estruturalmente intactas. As autoridades ocupantes conduziram políticas de acabar com ambas as burocracias, mas as exigências da reconstrução pós-guerra forçou-os a trazer de volta muitos exnazistas ou burocratas com ligações com os antigos regimes. No Japão em particular, o General Douglas MacArthur obteve sucesso ao extirpar apenas os principais oficiais dos poderosos ministérios da economia (FUKUYAMA, 2007a: 04)."

Independentemente das críticas pertinentes, Dobbins et al (2003) afirmam que as experiências na Alemanha e no Japão mostram que a democracia pode ser transferida e as sociedades podem ser encorajadas a se transformar, ainda que sob a supervisão das forças armadas interventoras. Todavia, nestes casos, devemos ter em mente que a transferência democrática 
foi possível porque ambas as sociedades tiveram experiência prévia com a democracia, eram homogêneas em termos étnicos e, talvez o mais importante, haviam sido derrotas em uma guerra de grandes proporções, diferentemente das demais operações, onde os conflitos ainda estavam em andamento.

A despeito dos resultados obtidos nas experiências acima citadas, outras operações de Nation-Building não foram empreendidas durante a Guerra Fria ${ }^{103}$. Conforme salientam Dobbins et al (2003), durante a Guerra Fria a política externa dos EUA apresentava uma postura de manutenção do status quo, conservando as esferas de influência de ambos os blocos e evitando confrontações diretas com a URSS. O poder militar dos EUA era usado para gerenciar crises oriundas da bipolaridade, não para acabar com ela. Isto não quer dizer que Washington se colocou em uma postura defensiva: esforços foram feitos para propagar valores democráticos e de livre-mercado: as instituições internacionais criadas com o apoio norte-americano e os golpes de Estado com suporte da CIA, principalmente na América Latina, são exemplos da postura ofensiva dos EUA ${ }^{104}$. No entanto, não temos nenhum desenvolvimento institucional com o objetivo de ao menos guardar as lições aprendidas $^{105}$.

No que tange às Operações de Paz, durante a Guerra Fria o apoio norte-americano era vital para o sucesso das missões, uma vez que Washington pagava a maior parte dos custos e a excelência dos EUA em logística militar era deveras importante ${ }^{106}$. Se durante a década de 1960 a ONU serviu aos interesses dos EUA, com as missões de paz estabilizando zonas de conflito que poderiam redundar em conflitos maiores entre EUA e URSS, na

103 Como salientado na seção sobre Nation-Building, o tema ainda é extremamente controverso. Ekbladh (2007) afirma que a reconstrução da Coréia pode ser considerada um caso de reconstrução de Estado enquanto Minxin Pei e Sarah Kasper (2003) arrolam 16 casos de Nation-Building, vários deles durante a Guerra Fria. As disparidades ocorrem porque os autores não possuem uma definição consensual sobre o tema, o que acaba redundando em casos distintos.

${ }^{104}$ Uma maior confrontação com a URSS é característica do governo Reagan (1981-1989), período conhecido como rebipolarização ou Segunda Guerra Fria. Para maiores detalhes sobre a política externa dos EUA, PECEQUILO (2005), AYERBE (2002) e SCHOULTZ (2000).

${ }^{105}$ Foram criadas algumas agências governamentais norte-americanas cujo objetivo era prover ajuda externa a outros países. Quiçá o melhor exemplo seja a USAID, criada durante a administração Kennedy, cujos aportes financeiros em assistência externa, de acordo com Ekblah (2007), chegaram a 2,9 bilhões em 1962. Contudo, uma unidade para lidar com NationBuilding e Operações de Paz ainda demoraria a ser criada.

${ }^{106}$ Durch (1996) afirma que durante a Guerra Fria, a atuação dos EUA nas Operações de Paz consistia no financiamento das missões, suporte logístico, transporte (principalmente aéreo) e alguns observadores em operações previamente selecionadas. 
década seguinte, como já salientado anteriormente, devido ao processo de descolonização em estágio avançado, a organização passou a ser vista como um fórum para o Terceiro Mundo, cujos interesses eram distintos daqueles buscados pelos EUA. Logo, conforme aponta Malone (2003), deteriorou-se a relação ONU-EUA, assim como o apoio às missões de paz.

De maneira similar à $\mathrm{ONU}$, os desenvolvimentos ocorridos na década de 1990 e todo o debate sobre a atuação norte-americana no pósGuerra Fria reavivaram as discussões sobre Operações de Paz e NationBuilding dentro da política externa dos EUA. O sucesso da Primeira Guerra do Golfo (1991) fez com que, conforme nos diz Durch (1996), a ONU passasse a ser vista novamente como um veículo para a consecução dos objetivos dos EUA. Ademais, dentro dos EUA os presidentes procuraram lidar com a questão de como enquadrar a ONU e as Operações de Paz em uma era em que os constrangimentos não estavam mais presentes.

Após o anúncio de uma Nova Ordem Mundial e do sucesso da Primeira Guerra do Golfo, na qual o Conselho de Segurança, atuando de forma rápida e consensual, condenou e viabilizou a criação de uma coalizão para impedir os ímpetos expansionistas de Saddam Hussein, George H. Bush enxergou um papel para a ONU na política externa dos EUA, principalmente no que tange às Operações de Paz. Assim sendo, conforme nos mostra Daalder (1996), o National Security Council criou um grupo de trabalho cuja missão era revisar a natureza e a extensão da participação dos EUA nas Operações de Paz da ONU. O resultado desta reavaliação foi anunciado pelo presidente em seu discurso perante a ONU em 21 de setembro de 1992, no qual reiterou seu apoio à organização e sublinhou algumas áreas que demandavam reformas, dentre as quais destacam-se melhorias nos sistemas de apoio logístico, aperfeiçoamento no sistema de inteligência e planejamento além de um financiamento adequado para as missões. Ademais, George H. Bush pagou os débitos dos EUA com a ONU, instruiu os militares a darem uma maior ênfase em planejamento e treinamento para as missões de paz e apoiou o aumento das operações da organização (HOLT e MACKINNON, 2008).

Internamente, os EUA também aumentaram a atenção para com as Operações de Paz. O Departamento de Defesa passou a dar mais importância ao tema, provendo maiores aportes de logística, transportes e 
comunicações para as missões, ensinando doutrinas de peacekeeping nas escolas militares, além de possibilitar o uso das bases norte-americanas alhures e de buscar novas formas de financiamento para as operações (DAALDER, 1996). Todavia, membros importantes da administração, dentre os quais o então secretário de Defesa Dick Cheney, questionavam como os EUA deveriam apoiar a ONU. Segundo eles, o país deveria emprestar suas capacidades logísticas; tropas em campo e equipamentos podiam ser providos por outros países.

De qualquer forma, foi durante esta administração republicana que veio à tona o primeiro documento devotado à temática das Operações de Paz: o National Security Decision Directive (NSDD). Embora o documento focasse sobremaneira em como a ONU deveria reformular suas operações, seu mérito foi ter colocado na agenda de segurança dos EUA a saliência das Operações de Paz. Entretanto, aprovado no final da administração republicana e com a vitória democrata no pleito seguinte, todo este processo foi interrompido, ficando a cargo do novo presidente avaliar qual seria o espaço da ONU e das Operações de Paz na política externa dos EUA.

Num primeiro momento, a administração capitaneada por Bill Clinton (1992-2000) apoiou as Operações de Paz com certo entusiasmo, enxergando-as como ferramentas para ajuda humanitária e para resolução de conflitos. Para melhor organizar a tarefa, a administração lançou primeiramente o Presidential Review Directive-13, um rascunho cuja ambição era rever todo o escopo das Operações de Paz, desde as missões tradicionais de Peacekeeping até as operações multidimensionais de Peace-Enforcement. Conforme aponta Daalder (1996), o rascunho afirmava que as Operações de Paz eram a melhor maneira para a comunidade internacional prevenir, conter e solucionar conflitos e fomentava um maior apoio às mesmas, ainda que afirmasse que os EUA manteriam sua capacidade de agir unilateralmente caso necessário. No que tange às decisões de quando intervir, deveria ficar claro para os EUA que a situação era uma real ameaça à ordem internacional, o que poderia incluir uma repentina e inesperada interrupção de uma democracia ou uma violação dos direitos humanos (apud DAALDER, 1996: 45). Ademais, ainda de acordo com o documento: 
"Os EUA podem contribuir com tropas se interesses específicos ou gerais do país possam ser avançados; se as tropas estão disponíveis sem qualquer impacto substancial nas Forças Armadas; se a participação é necessária para o sucesso da missão ou para persuadir outros a participarem; se o relacionamento entre 0 comando e o controle fosse aceitável; se uma estratégia de saída pudesse ser identificada; e se houvesse apoio doméstico, inclusive do Congresso, para a participação (DAALDER, 1996: 45-46)."

O sucesso do rascunho, contudo, não sobreviveu ao ocaso norteamericano na Somália. A morte dos soldados nas ruas de Mogadishu provocou a ira da opinião pública e do Congresso, que ainda contestava o aumento dos aportes financeiros para a ONU. Procurando responder às acusações de que os EUA estavam praticando uma política externa subserviente à ONU, a administração Clinton reescreveu o rascunho de 1993 e, em maio de 1994, publicou o Presidential Decision Directive - 25, que delineava o papel das Operações de Paz na política externa norte-americana. Embora parte do documento ainda fosse oriundo do rascunho de 1993, a nova publicação apresentava um tom mais cético, enfatizando que o papel das Forças Armadas dos EUA era proteger o interesse nacional por meio da dissuasão e, se necessário, lutando e vencendo guerras. Sumarizando, e seguindo a argumentação de Daalder (1996: 58):

"As Operações de Paz poderiam ser usadas para lidar com alguns, mas certamente não com todos, tipos de novos conflitos e de sofrimento humano que se tornaram corriqueiros no mundo pósGuerra Fria. Não obstante, o objetivo da política externa dos EUA não é nem expandir o número das operações da ONU nem fortalecer o envolvimento do país nas missões; pelo contrário, os EUA almejam garantir que o Peacekeeping torne-se mais seletivo e efetivo no futuro."

Com um Congresso com maioria republicana a partir de 1995, a administração Clinton passou a ter problemas para aprovar os financiamentos para as Operações de Paz. Em maio de 1997 Clinton publicou o novo Presidential Decision Directive - 56, intitulado Managing Complex Contingency 
Operations, o qual almejava codificar as lições aprendidas com as operações passadas, além de justificar o apoio norte-americano às missões. Ainda que a administração Clinton tenha publicado diversos documentos sobre o tema, Flournoy argumenta que, com exceção do Exército, que possui um sistema que avalia o fracasso e/ou sucesso de suas missões, o governo como um todo não possui organizações devotadas à identificação, análise e promulgação de lições aprendidas, seja de Nation-Building, seja de qualquer tipo de operações complexas (2007: 87).

Com as eleições de 2000 e a ascensão do republicano George W. Bush à Casa Branca, as lições e resultados alcançados durante a administração democrata foram deixados de lado, uma vez que, conforme nos conta Fareed Zakaria (2004), um das principais diretrizes de Bush em sua política externa foi sua regra $A B C$ : Anything But Clinton. Assim sendo, ao assumir o posto, a administração George W. Bush (2000-2008), composta por membros que outrora compuseram o governo de seu pai, George H. Bush ${ }^{107}$, procurou se distanciar da administração democrata e rejeitou o Protocolo de Kyoto sobre mudanças climáticas; rompeu com o Tratado de Mísseis AntiBalísticos firmado com a então URSS em 1972; congelou o processo de aproximação entre duas Coréias; além de não levar adiante o ingresso do país no Tribunal Penal Internacional.

Com relação às Operações de Paz, consoante Holt e Mackinnon (2008), o novo governo mostrou-se bastante cético sobre sua utilidade, porquanto achava que a atuação externa via organizações internacionais poderia constranger em demasia a política externa dos EUA. Há de se destacar

\footnotetext{
107 Segundo Lins da Silva (2002/2003: 52), em 1992, o atual vice-presidente, Dick Cheney, era o secretário de defesa; o atual secretário de Estado, Colin Powell, era o chefe do Estado-maior das Forças Armadas; o secretário adjunto de defesa, Paul Wolfowitz, era subsecretário de Defesa; o atual vice-chefe do Estado-maior das Forças Armadas, Lewis Libby, era o principal assessor de Wolfowitz; o atual assessor de Segurança Nacional do vice-presidente, Eric Edelman, era outro subsecretário de Defesa. O ex-secretário de Defesa, Donald Rumsfeld, estava fora do governo, mas mantinha as suas antigas relações de amizade com o clã Bush, em especial Cheney, seu colega durante a administração Gerald Ford. A influência dos chamados neoconservadores nos EUA vem sendo bastante debatida. Sabe-se que surgiram durante a década de 1970 dentro do Partido Democrata, de onde, após um racha, migraram para o Partido Republicano. Influentes na atual administração Bush, mantêm profunda convicção sobre a importância dos aspectos morais sobre a vida política, doméstica e externa, dos EUA postulam um poderio militar forte em escala global, uma política externa que promova os princípios norte-americanos no exterior assim como um multilateralismo que não constranja a atuação estadunidense no cenário internacional. Maiores detalhes sobre os neoconservadores, Ayerbe (2006) e Teixeira (2007).
} 
também que Bush enfatizara durante sua campanha que a administração Clinton, com sua política externa assaz ambiciosa e sem foco, desgastara em demasia a força militar dos EUA, utilizando o exército para operações de Nation-Building que não tinham qualquer conexão com os interesses nacionais. O então Secretário de Defesa Donald Rumsfeld, coadunando-se com esta postura, tentou diminuir o contingente de algumas missões, em especial na Bósnia e em Kosovo. No entanto, após uma forte pressão dos aliados europeus, Bush aquiesceu e fez uma pequena redução em suas tropas na Bósnia em maio de 2001, mas manteve as tropas em Kosovo.

Todavia, os ataques terroristas de Onze de setembro provocariam uma importante inflexão nas decisões outrora tomadas, principalmente naquelas referentes às Operações de Paz e Nation-Building. Outrora o principal opositor ao Nation-Building, o presidente republicano tornou-se quiçá o principal Nation-Builder da história dos EUA, empreendendo em menos de dois anos duas grandes operações que até o presente momento ainda estão em andamento. A constatação da conexão entre um Estado Falido como o Afeganistão e grupos terroristas fez com que a administração Bush, segundo Litwak (2007: xiii), afirmasse que os EUA enfrentam ameaças oriundas das características intrínsecas de seus adversários - Estados párias imprevisíveis e grupos terroristas que não podem ser dissuadidos. Dessa forma, a chamada Doutrina Bush, caracterizada pelos ataques preventivos e por propor uma mudança de regime em Estados Falidos cuja capacidade de retaliação é extremamente baixa, se é que possuem alguma capacidade para tanto ${ }^{108}$, tornou-se o melhor instrumental para se lidar com a natureza das novas ameaças. Conforme Daalder e Lindsay (2003: 02):

"Bush colocou em marcha uma revolução na política externa norteamericana. Não foi uma revolução nos objetivos externos dos EUA e sim na maneira em como atingi-los. Optou pelo exercício unilateral do poder americano ao invés do direito internacional e das instituições. Utilizou uma pró-ativa doutrina de prevenção em detrimento de estratégias reativas como a dissuasão e a contenção.

\footnotetext{
${ }^{108}$ Ayerbe (2006) afirma que se para os Estados militarmente fracos a Doutrina Bush é a ferramenta considerada adequada pela administração, para os Estados fortes, tais como China e Rússia, a Dissuasão ainda é a estratégia utilizada.
} 
Promoveu intervenções pela força e ataques preventivos como uma maneira de conter a proliferação de armas de destruição em massa além de retirar o tradicional suporte norte-americano para tratados e regimes de não-proliferação. Preferiu coalizões ad hoc para angariar suporte internacional e ignorou alianças permanentes, além de tentar unir os grandes poderes na causa comum do combate ao terrorismo."

Assim sendo, em sua Estratégia de Segurança Nacional (National Security Strategy) de 2002, assim como na revisão publicada em 2006, os ataques preventivos, justificados em termos de que a inação pode ser mais perigosa do que a incerteza quanto à hora e o local do ataque inimigo, caminham pari passu com a idéia de que uma economia mundial caracterizada pelo livre-comércio otimizaria a segurança nacional do país ao prover mais prosperidade e liberdade ao resto do mundo. Presente já na primeira publicação, conquanto mais enfática na revisão de março de 2006, está a percepção de que o terrorismo transnacional advém da falta de liberdade em regimes tirânicos e de Estados Falidos, os quais não conseguiram atingir o que o documento cunha como democracias efetivas. Segundo a Estratégia revista de 2006, uma democracia efetiva seria aquela que (1) garante os direitos humanos básicos além de liberdade de expressão, liberdade religiosa, entre outros; (2) seja responsiva para com seus cidadãos; (3) exerça soberania efetiva e mantenha a ordem dentro de suas fronteiras, assim como tenham um sistema de justiça imparcial e estabeleça o estado de direito; e (4) limite o tamanho do governo, deixando espaço para associações da sociedade civil e para a economia de mercado (BUSH, 2006: 04).

Por conseguinte, o ceticismo face as Operações de Paz e as operações de Nation-Building deram espaço para uma abordagem mais pragmática, conforme Holt e Mackinnon (2008). Num primeiro momento, a ONU passou a ser vista como um veículo adequado para não apenas atuar na operação no Afeganistão como também para angariar suporte de outros países e legitimidade internacional ${ }^{109} \mathrm{e}$, ainda para transformar o comportamento dos

\footnotetext{
${ }^{109}$ É importante destacar que o argumento dos EUA para a intervenção no Afeganistão não foi calcada em assistência humanitária, tampouco em alegações de que o Talibã desrespeitava os direitos humanos. A alegação foi de que a Al-Qaeda, com suporte do Talibã, atacara o território
} 
Estados meliantes, conforme adjetivação proposta pelo presidente Bush na Estratégia de Segurança Nacional de 2002. Dessa forma, para resolver os atuais problemas de segurança internacional, seria necessário mudar as características internas dos países e transformá-los em democracias efetivas; logo, o meio mais adequado seriam as operações de Nation-Building. Embora a posterior intervenção militar no Iraque em 2003 não tenha angariado o apoio do Conselho de Segurança e dos tradicionais aliados europeus, Stewart Patrick (2008: 135) argumenta que:

\begin{abstract}
"A nova saliência estratégica dos Estados fracos e falidos resultou, ao menos inicialmente, nem em um maior engajamento das missões lideradas pela ONU, tampouco em um comprometimento com Nation-Building multilateral. Ao invés disso, os ataques reforçaram os instintos unilaterais da administração. Para levar adiante a sua guerra contra o terrorismo, os EUA iriam ocasionalmente engajar-se com instituições internacionais - notadamente a ONU - para atingir seus objetivos de segurança. No entanto, insistiriam que a guerra fosse levada adiante conforme suas diretrizes.(...) É a missão que determina a coalizão"
\end{abstract}

Sob este prisma, não é surpreendente notar que mesmo com as relações chamuscadas pela controversa intervenção no Iraque, os EUA tenham aumentado seu apoio às Operações de $\mathrm{Paz}$, principalmente na África. Conforme bem apontado por Patrick (2008), ao enquadrar as operações sob o prisma da Guerra ao Terrorismo, na medida em que estas poderiam ser utilizadas para assistir territórios que poderiam ser santuários para grupos terroristas, a administração Bush apoiou um fortalecimento da ONU e da União Africana (UA) para lidar com Estados Falidos; criou um programa dentro do Pentágono para treinar e equipar forças militares em Estados fracos; e, por fim, deu ensejo para o desenvolvimento de um novo comando de combate para a África (AFRICOM), com um foco especial para a segurança regional no continente, atuando conjuntamente com outras agências norte-americanas,

dos EUA, outorgando aos EUA a possibilidade de justificar suas ações utilizando o argumento da legítima defesa. 
como a USAID ${ }^{110}$. No que tange a USAID, a reforma da instituição em 2002 culminou na criação do Escritório para Gerenciamento e Mitigação de Conflitos, o qual procura entender a eclosão de conflitos civis por meio de uma análise holística, abordando desde fatores econômicos e políticos, pressões internacionais e tensões étnico-religiosas.

Assim sendo, tornou-se imperativa uma reestruturação interna nos EUA para que o país pudesse desenvolver e coordenar as operações de Nation-Building. Com apoio do Congresso, o Departamento de Estado criou o Escritório do Coordenador para Reconstrução e Estabilização (Office of the Coordinator for Reconstruction and Stabilization - S/CRS) em julho de 2004 que, segundo Bensahel (2007), teria como meta liderar, coordenar e institucionalizar a capacidade civil do governo dos EUA para prevenir e preparar para situações de pós-conflito, ajudando os países na transição para a democracia e economia de mercado. Uma vez estabelecido, o escritório procurou compilar lições aprendidas de operações prévias e desenvolver um banco de dados de civis que poderiam ser enviados para as missões. Além disso, desenvolveu diretrizes para engajamento em situações de conflito e procurou parcerias com outros países e organizações não-governamentais para aumentar as capacidades civis de reconstrução. Segundo Bensahel (2007: 44):

"O escritório começou diversas iniciativas em países específicos, liderando os esforços de coordenação política entre agências para ajudar a identificar medidas de prevenção de conflitos específicas. Também patrocinou o grupo de coordenação para a reconstrução e estabilização do Sudão, e coordena o suporte norte-americano para a implementação do Acordo de Paz de 2005. Ademais, lidera os esforços estratégicos dos EUA na transformação democrática do Haiti e teve um papel importante juntamente com a ONU na coordenação nas eleições haitianas de 2006. Por fim, apoiou os trabalhos do coordenador norte-americano para Cuba e trabalhou

\footnotetext{
${ }^{110}$ Devemos salientar que este apoio às Operações de Paz foi maior em locais em que há a constatação de que existem Estados Falidos e com possibilidade de se tornarem abrigos para grupos terroristas. Em outras regiões, como, por exemplo, a América Latina, a Guerra ao Terror veio por meio da pressão sobre os governos nacionais para que evitem a proliferação de grupos terroristas em seus territórios, como é a atual conjuntura na Tríplice Fronteira entre Brasil, Argentina e Paraguai. Para maiores detalhes sobre a política de segurança dos EUA para a América Latina, VILLA (2007).
} 
nos esforços para prevenção de conflitos no Congo, Nepal, Zimbábue, entre outros."

Em dezembro de 2005, na mesma leva de reformas sobre NationBuilding, o presidente Bush publicou um Presidential Decision Directive, intitulado Management of Interagency Efforts Concerning Reconstruction and Stabilization, o qual substituía as decisões da administração Clinton sobre o tema e apontava as novas diretrizes. Segundo o documento, o Departamento de Estado se tornaria a unidade para planejar, preparar e conduzir as atividades de reconstrução e estabilização. Por fim, estabelece a criação de um Comitê de Coordenação Política para Operações de Reconstrução e Estabilização (Policy Coordination Committee for Reconstruction and Stabilization Operations), um mecanismo formal para a coordenação entre as agências.

Não obstante, o S/CRS ainda enfrenta problemas. De acordo com Patrick (2008), resistências burocráticas dentro do Departamento de Estado, rivalidades entre as agências do governo e, por mais surreal que possa parecer, as negativas do governo em integrar o novo órgão nas reconstruções do Iraque e do Afeganistão minaram a autoridade do escritório e seu poder de decisão ${ }^{111}$. Em segundo lugar, possui um mandato extremamente ambicioso a ser cumprido que, sem o devido apoio do Executivo, torna-se praticamente impossível de ser realizado. Por fim, os problemas com o financiamento da nova unidade impedem que as tarefas sejam cumpridas. Além de possuir poucos recursos humanos - em abril de 2007, conforme Bensahel (2007), eram apenas 74 pessoas - o orçamento destinado, após muitos debates com 0 Congresso e disputas com outras agências, ficou restrito a 100 milhões de dólares.

Da mesma forma que a realizada na seção anterior, é importante passarmos em revista as operações de Nation-Building comandadas pelos

\footnotetext{
${ }^{111} \mathrm{Na}$ pesquisa realizada para o presente trabalho, nenhum autor procurou desvendar $\mathrm{o}$ porquê desta situação. Não obstante, nossa hipótese, que certamente precisaria de maiores dados para uma confirmação, é a de que a competição por recursos entre as burocracias impediu que o escritório tomasse a liderança das operações no Iraque e Afeganistão. Sabe-se que os recursos destinados para as missões são vultosos e que o Pentágono, um dos principais - senão o principal - coordenadores dificilmente delegaria a tarefa, juntamente com os recursos financeiros, para um novo órgão, perdendo boa parte do poder de decisão e de influência.
} 
EUA. Segundo Dobbins et al (2003), os EUA empreenderam sete missões, sem contar a atual intervenção no Iraque ${ }^{112}$ : Alemanha e Japão, durante a Guerra Fria; Somália, Haiti, Bósnia e Kosovo no pós-Guerra Fria; e Afeganistão, depois do Onze de setembro de 2001. Tendo em mente que a situação na Somália já foi descrita no capítulo anterior e que o Afeganistão será o protagonista do próximo capítulo, as descrições abaixo se limitam aos casos do Haiti, Bósnia e Kosovo.

O caso do Haiti nos remete à eleição presidencial de 1990, na qual se sagrou vencedor Jean-Bertrand Aristidie. No entanto, nove meses após o final do pleito, um golpe militar comandado pelo General Raul Cedras findou com o governo democraticamente eleito e forçou a saída de Aristidie do país. Após três anos de pressões internacionais por meio de sanções econômicas e eventuais ameaças de intervenção militar, Raul Cedras aquiesceu e assinou um acordo no qual abria espaço para uma coalizão liderada pelos EUA trazer de volta ao poder o presidente Aristidie.

A operação visava primeiramente garantir o retorno de Aristidie para, em seguida, abolir o exército e criar uma nova força policial. Ademais, novas eleições locais e nacionais foram realizadas, assim como a criação e concomitante treinamento de novas estruturas governamentais. Todavia, ainda sofrendo do efeito Somália, os EUA anteciparam a saída do Haiti para evitar que Port au Prince se tornasse uma nova Mogadishu. Esta saída precipitada evitou uma maturação das instituições recém-criadas assim como a implementação das reformas econômicas que almejavam alavancar a economia do país. De acordo com Dobbins et al (2003), inicialmente a operação no Haiti foi bem sucedida, pois alcançou seu objetivo primário; porém, as etapas ulteriores não foram completadas o que comprometeria sobremaneira o futuro do país.

A dissolução da lugoslávia após o final da Guerra Fria foi o evento que precipitou não apenas a operação na Bósnia, como também na

\footnotetext{
${ }^{112}$ Minxin Pei e Sarah Kasper (2003), por terem uma definição diferente de Nation-Building, apontam 16 casos: três vezes em Cuba (1898-1902, 1906-1909, 1917-1922); duas vezes no Panamá (1903-1936, 1989); Nicarágua (1909-1933); Haiti (1915-1934); duas vezes na República Dominicana (1916-1924, 1965-1966); Alemanha (1945-1949); Japão (1945-1952); Vietnã (1964-1973); Camboja (1970-1973); Granada (1983); Haiti (1994-1996); e Afeganistão (2001-hoje).
} 
Croácia, explicitada na seção anterior. Após as independências da Croácia e da Eslovênia em 1991, a Bósnia seguiu caminho similar e um referendo em inícios de 1992 garantiu a vitória dos partidários pela independência do país. A declaração de independência deu início a uma guerra civil, na qual a impossibilidade de unificar os diferentes grupos étnicos existentes no território levou à adoção por parte dos líderes nacionalistas, dentre eles Slobodan Milosevic, de uma política de Limpeza Étnica: sérvios iniciaram a purificação do território eliminando croatas e muçulmanos e, em 1994, de acordo com o cômputo de Dobbins et al (2003), 200.000 soldados e civis haviam sido mortos ou estavam desaparecidos, sem contar os quase 2 milhões de refugiados e pessoas internamente dispersas.

A partir de 1995, uma ofensiva combinada entre croatas e bósnios começou a fazer avanços consideráveis na Bósnia, sem contar o suporte dado pelos EUA e pela OTAN, que iniciaram a operação Deliberate Freedom após as forças sérvias terem atacado um mercado em Sarajevo. A combinação dos avanços bósnios e croatas conjuntamente com a ação da OTAN deu ensejo para que os contendores iniciassem conversações de paz, as quais resultariam nos Acordos de Dayton, cujas metas incluíam a separação e desmobilização das milícias, o retorno dos refugiados e dos dispersos internamente. Ademais, como apontam Dobbins et al (2003: 88-89):

"O Acordo de Dayton criou duas entidades dentro do mesmo território que era praticamente idênticos em tamanho: a federação Bósnica-Croata, que controla $51 \%$ do território do país, e a República Srpska, que controla 49\%. A Conferência de 8 e 9 de dezembro de 1995, realizada em Londres, apontou um Alto Representante para verificar a implementação do acordo. Enquanto isso, a OTAN enviou 60.000 soldados para a Implementation Force (IFOR) para garantir os artigos militares do Acordo de Dayton."

Segundo Messari (2004), a evolução política na Bósnia foi bastante comentada, visto que notamos o fim dos embates entre os antigos contendores, o encarceramento de vários criminosos de guerra pertencentes às três facções além da diminuição do papel desempenhado pelas agências internacionais na administração do território. Todavia, em consonância com o 
mesmo autor, deparamo-nos com um retorno lento dos refugiados, uma difícil integração entre os três grupos étnicos e a presença internacional, principalmente das tropas norte-americanas e da OTAN, ainda se faz necessária para manter o território integrado. Segundo Dobbins et al (2003), a administração Clinton impôs um tempo de duração para a missão extremamente curto, o que culminou em eleições apressadas e o comprometimento financeiro da comunidade internacional para com a Bósnia foi o que possibilitou um crescimento econômico acelerado. Contudo, mais de dez anos após a assinatura dos Acordos de Dayton, ainda é cedo para afirmar que a Bósnia é uma entidade política e econômica auto-sustentável.

Finalmente, o último caso de Nation-Building antes do Onze de setembro de 2001 foi o realizado em Kosovo. Em 1989 Slobodan Milosevic revogou o status de província autônoma de Kosovo, deu fim às instituições locais de governo e impôs controle direto de Belgrado, substituindo os kosovares albanianos por sérvios para as principais posições políticas da região. Inicialmente, a resistência kosovar deu-se em termos pacíficos; porém, com o decorrer do tempo, essa mesma resistência adquiriu formas militantes, culminando na ascensão do Exército de Libertação de Kosovo (Kosovo Liberation Army - KLA). O embate entre sérvios e kosovares produziu baixas significativas de ambos os lados, além de um grande número de refugiados e dispersos internamente.

Somente em 1998 a comunidade internacional resolveu atuar. Em 24 de março iniciaram-se os bombardeios aéreos da OTAN liderados pelos EUA, cujo estopim foi a negativa de Belgrado sobre o acordo interino que se havia firmado em uma conferência em Rambouillet, na França. Em 03 de julho de 1999, após severos ataques aéreos e a iminência de uma invasão por terra, Slobodan Milosevic aceitou as condições impostas por EUA e OTAN. Ademais, a resolução 1244 do Conselho de Segurança da ONU deu as diretrizes para a reconstrução do território, com a organização liderando a administração civil e preparando o ambiente para um governo democrático e autônomo e a OTAN tomando conta do setor militar, assistindo tanto a segurança interna quanto a externa.

Das operações lideradas pelos EUA, Dobbins et al (2003) afirmam que a de Kosovo foi a mais bem sucedida. OTAN e EUA dividiram a 
responsabilidade no que tange à segurança enquanto a ONU liderava os aspectos administrativos e civis da reconstrução. Dessa forma, foi possível alcançar os principais objetivos da missão: desmilitarizar as milícias, realizar eleições e iniciar reformas econômicas, as quais incluíram a criação de um banco central, de um tesouro público e de um ministério das finanças, visto que, por ter sido outrora província sérvia, Kosovo não possuía o aparato financeiro necessário em um país. A União Européia foi a responsável pela reconstrução econômica do território e as organizações internacionais e outros doadores injetaram, conforme cômputo de Dobbins et al (2003), 671 milhões de dólares nos últimos seis meses de 1999 e 704 milhões em 2000. A única pendência restringiu-se ao status da província, que só viria a ser resolvido atualmente, com a declaração de independência do país e o apoio da comunidade internacional.

Após a análise breve realizada sobre as missões dos EUA e tendo-se em mente os estudos de caso realizados pela Rand Corporation, tanto nas operações da ONU (DOBBINS ET AL, 2005) quanto nas dos EUA (DOBBINS ET AL, 2003), percebemos que os EUA possuem a capacidade para montarem um efetivo muito maior que aqueles forjados para as missões da ONU. No caso da Alemanha pós-Segunda Guerra Mundial, os EUA enviaram 1,6 milhões de soldados, operação com o maior contingente, enquanto que em Kosovo, os EUA enviaram apenas 15.000 soldados, número este que contém também soldados da OTAN. O menor contingente norteamericano ainda é bastante alto quando comparado aos números da ONU, conforme mostrado no final da seção anterior. Por fim, segundo o raciocínio de Dobbins et al (2005: xxx):

"As missões da ONU tendem a ser menores que as dos EUA, são empreendidas em circunstâncias menos complexas, são mais freqüentes e, portanto, mais numerosas, possuem objetivos mais bem definidos, e - ao menos nos casos estudados - apresentam uma taxa de sucesso maior. Por outro lado, as operações lideradas pelos EUA foram empreendidas em circunstâncias mais complexas, requerem mais forças e mandatos mais robustos, recebem mais ajuda econômica, apresentam objetivos mais ambiciosos, e - nos casos estudados - têm dificuldades para atingir seus objetivos." 


\section{Abaixo, as tabelas retiradas de Dobbins et al (2005: xxxi-xxxiv).}

Table S.3

Major Nation-Building Operations: 1945 -Present

\begin{tabular}{|c|c|c|c|c|c|}
\hline Country & Years & Peak Troops & Lead Actors & Assessment & Lessons Learned \\
\hline West Germany & $1945-1952$ & 1.6 million & $\begin{array}{l}\text { Led by U.S, British, } \\
\text { and French }\end{array}$ & $\begin{array}{l}\text { Very successful. Within } 10 \\
\text { years an economically stable } \\
\text { democratic and NATO member } \\
\text { state. }\end{array}$ & $\begin{array}{l}\text { Democracy can be transferred. } \\
\text { Military forces can underpin } \\
\text { democratic transformation. }\end{array}$ \\
\hline Japan & $1945-1952$ & 350,000 & U.S.-led & $\begin{array}{l}\text { Very successful. Economically } \\
\text { stable democratic and regional } \\
\text { security anchor within a decade. }\end{array}$ & $\begin{array}{l}\text { Democracy can be exported } \\
\text { to non-Western societies. } \\
\text { Unilateral nation-building can } \\
\text { be simpler than multilateral. }\end{array}$ \\
\hline Congo & $1960-1964$ & 19,828 & UN-led & $\begin{array}{l}\text { Partially successful, costly } \\
\text { and controversial. UN ensured } \\
\text { decolonization and territorial } \\
\text { integrity, but not democracy. }\end{array}$ & $\begin{array}{l}\text { Money and manpower demands } \\
\text { almost always exceed supply. } \\
\text { Controversial missions leave } \\
\text { legacies of "risk aversion." }\end{array}$ \\
\hline Namibia & $1989-1990$ & 4,493 & UN-led & $\begin{array}{l}\text { Successful. UN helped ensure } \\
\text { peace, democratic development, } \\
\text { and economic growth. }\end{array}$ & $\begin{array}{l}\text { Compliant neighbors, a } \\
\text { competent government, and a } \\
\text { clear end state can contribute to } \\
\text { successful outcome. }\end{array}$ \\
\hline El Salvador & $1991-1996$ & 4,948 & UN-led & $\begin{array}{l}\text { Successful. UN negotiated lasting } \\
\text { peace settlement and transition } \\
\text { to democracy after } 12 \text {-year civil } \\
\text { war. }\end{array}$ & $\begin{array}{l}\text { UN participation in settlement } \\
\text { negotiations can facilitate } \\
\text { smooth transition. }\end{array}$ \\
\hline Cambodia & $1991-1993$ & 15,991 & UN-led & $\begin{array}{l}\text { Partially successful. UN } \\
\text { organized elections, verified } \\
\text { withdrawal of foreign troops and } \\
\text { ended large-scale civil war. But } \\
\text { democracy did not take hold. }\end{array}$ & $\begin{array}{l}\text { Democratization requires long- } \\
\text { term engagement. }\end{array}$ \\
\hline
\end{tabular}

Table S.3-Continued

\begin{tabular}{|c|c|c|c|c|c|}
\hline Country & Years & Peak Troops & Lead Actors & Assessment & Lessons Learned \\
\hline Somalia & $1992-1994$ & 28,000 & $\begin{array}{l}\text { UN-led } \\
\text { peacekeeping } \\
\text { mission, followed } \\
\text { by US-led coalition, } \\
\text { followed by UN } \\
\text { led peacekeeping } \\
\text { mission }\end{array}$ & $\begin{array}{l}\text { Not successful. Little } \\
\text { accomplished other than some } \\
\text { humanitarian aid delivered to } \\
\text { Mogadishu and other cities. }\end{array}$ & $\begin{array}{l}\text { Unity of command can be } \\
\text { important in peace as in combat } \\
\text { operations. Nation-building } \\
\text { objectives must be scaled to } \\
\text { available resources. }\end{array}$ \\
\hline Mozambique & $1992-1994$ & 6,576 & UN-led & $\begin{array}{l}\text { Mostly successful. Transition } \\
\text { to independence was peaceful } \\
\text { and democratic. But negative } \\
\text { economic growth. }\end{array}$ & $\begin{array}{l}\text { Cooperation of neighboring } \\
\text { states is critical to success. } \\
\text { Incorporation of insurgent } \\
\text { groups into political process is } \\
\text { key to democratic transition. }\end{array}$ \\
\hline Haiti & $1994-1996$ & 21,000 & $\begin{array}{l}\text { U.S.-led entry, } \\
\text { followed by UN- } \\
\text { led peacekeeping } \\
\text { mission with large } \\
\text { U.S. component }\end{array}$ & $\begin{array}{l}\text { Initially successful but ultimately } \\
\text { not. U.S. forces restored } \\
\text { democratically elected president } \\
\text { but U.S. and UN left before } \\
\text { democratic institutions took } \\
\text { hold. }\end{array}$ & $\begin{array}{l}\text { Exit deadlines can be } \\
\text { counterproductive. Need time to } \\
\text { build competent administrations } \\
\text { and democratic institutions. }\end{array}$ \\
\hline Bosnia & $\begin{array}{l}\text { 1995- } \\
\text { present }\end{array}$ & 20,000 & $\begin{array}{l}\text { U.S./NATO-led } \\
\text { military } \\
\text { component, ad } \\
\text { hoc coalition civil } \\
\text { component, largely } \\
\text { U.S. and EU }\end{array}$ & $\begin{array}{l}\text { Mixed success. Democratic } \\
\text { elections within two years, but } \\
\text { government is constitutionally } \\
\text { weak. }\end{array}$ & $\begin{array}{l}\text { Nexus between organized crime } \\
\text { and political extremism can be } \\
\text { serious challenge to enduring } \\
\text { democratic reforms. }\end{array}$ \\
\hline
\end{tabular}


Table S.3-Continued

\begin{tabular}{|c|c|c|c|c|c|}
\hline Country & Years & PeakTroops & Lead Actors & Assessment & Lessons Learned \\
\hline $\begin{array}{l}\text { Eastern } \\
\text { Slavonia }\end{array}$ & $1995-1998$ & 8,248 & UN-led & $\begin{array}{l}\text { Successful. Well-resourced } \\
\text { operation and clear end state } \\
\text { contributed to peaceful and } \\
\text { democratic transition. }\end{array}$ & $\begin{array}{l}\text { UN can successfully conduct } \\
\text { small peace enforcement } \\
\text { missions with support from } \\
\text { major powers. }\end{array}$ \\
\hline Sierra Leone & $\begin{array}{l}\text { 1998- } \\
\text { present }\end{array}$ & 15,255 & $\begin{array}{l}\text { UN-led, parallel UK } \\
\text { force in support }\end{array}$ & $\begin{array}{l}\text { Initially unsuccessful, then } \\
\text { much improved. Parallel British } \\
\text { engagement helped stabilize } \\
\text { mission. }\end{array}$ & $\begin{array}{l}\text { Lack of support from major } \\
\text { powers can undermine UN } \\
\text { operations. But even a badly } \\
\text { compromised mission can be } \\
\text { turned around. }\end{array}$ \\
\hline East Timor & $\begin{array}{l}\text { 1999- } \\
\text { present }\end{array}$ & 8,084 & $\begin{array}{l}\text { Australian-led entry } \\
\text { followed by UN- } \\
\text { led peacekeeping } \\
\text { mission }\end{array}$ & $\begin{array}{l}\text { Successful. UN oversaw } \\
\text { transition to democracy, peace, } \\
\text { and economic growth. }\end{array}$ & $\begin{array}{l}\text { Support of neighboring states } \\
\text { is important for security. Local } \\
\text { actors should be involved as early } \\
\text { as possible in governance. }\end{array}$ \\
\hline Kosovo & $\begin{array}{l}\text { 1999- } \\
\text { present }\end{array}$ & 15,000 & $\begin{array}{l}\text { U.S./NATO-led } \\
\text { entry, followed } \\
\text { by NATO-led } \\
\text { peacekeeping, } \\
\text { UN-led civil } \\
\text { governance, } \\
\text { OSCE-led } \\
\text { democratization, } \\
\text { and EU-led } \\
\text { reconstruction }\end{array}$ & $\begin{array}{l}\text { Mostly successful. Elections } \\
\text { within } 3 \text { years and strong } \\
\text { economic growth. But no final } \\
\text { resolution of Kosovo's status. }\end{array}$ & $\begin{array}{l}\text { Broad participation, and } \\
\text { extensive burden sharing } \\
\text { can be compatible with unity } \\
\text { of command and American } \\
\text { leadership. }\end{array}$ \\
\hline
\end{tabular}

Table S.3-Continued

\begin{tabular}{|c|c|c|c|c|c|}
\hline Country & Years & Peak Troops & Lead Actors & Assessment & Lessons Learned \\
\hline Afghanistan & $\begin{array}{l}2001- \\
\text { present }\end{array}$ & 20,000 & $\begin{array}{l}\text { U.S.-led entry and } \\
\text { counterinsurgency, } \\
\text { UN-led } \\
\text { democratization, } \\
\text { and NATO-led } \\
\text { peacekeeping }\end{array}$ & $\begin{array}{l}\text { Too soon to tell. Democratic } \\
\text { elections and decline as a } \\
\text { base for terrorism. But little } \\
\text { government control beyond } \\
\text { Kabul, and rising drug and } \\
\text { insurgency challenges. }\end{array}$ & $\begin{array}{l}\text { Low initial input of money and } \\
\text { troops yields a low output of } \\
\text { security, democratization, and } \\
\text { economic growth. }\end{array}$ \\
\hline Iraq & $\begin{array}{l}\text { 2003- } \\
\text { present }\end{array}$ & 175,000 & $\begin{array}{l}\text { U.S.-led entry, } \\
\text { occupation, and } \\
\text { counterinsurgency }\end{array}$ & $\begin{array}{l}\text { Too soon to tell. Overthrow of } \\
\text { Saddam Hussein's brutal regime. } \\
\text { But insurgency has slowed } \\
\text { reconstruction efforts. }\end{array}$ & $\begin{array}{l}\text { Postwar planning is as important } \\
\text { as planning for the conflict. }\end{array}$ \\
\hline
\end{tabular}




\section{NATION-BUILDING NO AFEGANISTÃO}

"Os americanos podem ficar por cinco, dez anos, mas eventualmente eles partirão e quando isso acontecer, nós iremos retornar às provinciais e mataremos todas aquelas famílias que colaboraram com eles e com o governo Karzai ${ }^{113}$."

Percorridos os capítulos anteriores, nos quais procuramos explicitar a gênese, as controvérsias e os atores envolvidos com NationBuilding, estamos aptos para enfim tratarmos da reconstrução do Afeganistão. A despeito da maior atenção tanto da mídia quanto do governo norteamericano ao caso do Iraque, a situação afegã possui traços particulares que a tornam singular. Primeiramente, o contexto interno do país foi o estopim para os atentados terroristas de Onze de setembro de 2001, provocando uma importante inflexão na política externa dos EUA, visto que até então a administração republicana era contrária às operações de Nation-Building. Em segundo lugar, apesar de Dobbins et al (2003) apontarem a operação como liderada pelos EUA, a ONU possui um papel assaz importante, quiçá maior que o desenvolvido por Washington. Por fim, conforme muito bem apontado por Rubin (2007), temos atualmente em território afegão grupos terroristas operando a partir da fronteira com o Paquistão com o beneplácito de Islamabad, o que torna a região palco imprescindível da Guerra ao Terror, ainda que negligenciado pelos EUA.

Reconhecendo que retratar pormenorizadamente cada aspecto desta operação seria apropriado para uma etapa de estudos mais avançada, optamos por fazer a seguinte divisão. Em primeiro lugar, apresentaremos a conjuntura em que se iniciou a reconstrução do país, após a queda do Talibã, o início da Operação Liberdade Duradoura e os acordos em Bonn. Em seguida, mostraremos os desafios enfrentados pelo Afeganistão e quais foram os Inputs investidos no país, conforme os moldes de Dobbins et al (2003). Ao final, apontaremos o que foi alcançado, qual a atual situação do país e quais são os desafios que ainda assombram o futuro do Afeganistão.

${ }^{113}$ Discurso de uma liderança Talibã, apud JOHNSON e MASON (2006: 17) 


\subsection{DE CABUL A BONN}

Conforme destacado anteriormente, em 07 de outubro de 2001 os EUA iniciaram a Operação Liberdade Duradoura que, segundo Daalder e Lindsay (2003), objetivava acabar com o uso do Afeganistão como santuário para grupos terroristas e destruir a capacidade militar do regime do Talibã, conquanto os mesmos autores apontem falta de clareza nos objetivos da missão. Para tanto, ainda que houvesse reticências no governo norteamericano $^{114}$, a estratégia consistiu em apoiar os avanços terrestres da Aliança do Norte enquanto, de outro lado, os EUA se encarregariam de ataques aéreos. Todavia, o suporte terrestre norte-americano após os primeiros bombardeios também se fez necessário.

A queda do Talibã e a vitória da Aliança do Norte culminaram em uma situação em que os principais postos do governo, além dos governos das províncias, fossem ocupados pelos Tajiks e Uzbeks, principais grupos étnicos de oposição aos Pashtun, etnia majoritária do país e principal fonte dos recursos humanos do Talibã. Segundo salientado por Starr (2007), todos os ministros, governadores e membros do staff administrativo eram Tajiks oriundos do Vale do Panjshir, reduto da Aliança do Norte. De fora desta equação ficaram os Pashtun, os Hazaras, outras etnias importantes do Afeganistão.

A nova divisão do poder no Afeganistão, realizada após a queda do Talibã, foi levada adiante quando se iniciaram as conversações de paz. Após a aprovação da Resolução 1378 do Conselho de Segurança, que conclamava pela construção de um novo governo que deveria representar toda a sua população e que outorgava à ONU um papel importante na reconstrução, as principais lideranças do país se reuniram em Bonn, na Alemanha, para decidir sobre a transição e a natureza do governo democrático a ser instalada em um território com pouca experiência prévia no assunto. Todavia, a despeito da composição das lideranças presentes, que agregavam não apenas a Aliança do Norte, como também o Grupo de Roma, composto pelo ex-rei Zahir

\footnotetext{
${ }^{114}$ Segundo Daalder e Lindsay (2003), nos altos escalões do governo a dúvida se referia se o apoio à Aliança do Norte era a melhor estratégia ou se os EUA deveriam optar por uma invasão terrestre.
} 
Shah, o Grupo de Peshawar, de maioria Pashtun e o Grupo do Chipre, com laços próximos ao Irã, os Tajiks mantiveram a sua proeminência na composição do governo, em muito bancada pelos EUA.

Os acordos de Bonn não ambicionaram mexer na composição étnica emergente. Pelo contrário, as metas das conversações eram criar as novas instituições políticas com as quais as novas lideranças deveriam lidar. Para tanto, estabeleceu-se uma autoridade interina que ao cabo de seis meses daria lugar para uma Autoridade de Transição (Transitional Authority), eleita por uma Loya Jirga Emergencial (Emergency Loya Jirga) e que lideraria o país no processo de reconstrução das principais instituições do país. Oito meses após a posse da Autoridade de Transição, uma Loya Jirga Constitucional (Constitutional Loya Jirga) deveria ser organizada para a elaboração de uma nova Constituição para o país e, em seguida, possibilitar as eleições para o Executivo e o Legislativo do país. Segundo Thier (2004: 47):

\begin{abstract}
"Os acordos de Bonn colocaram em andamento dois processos simultâneos: a reconstrução do Estado e a consolidação da paz. A reconstrução ambicionava ser o motor para a formação de arranjos de segurança de longo prazo e o retorno de uma unidade nacional. O processo de consolidação da paz foi pensado para manter a ordem entre as facções, permitindo que diminuíssem sua animosidade ao mesmo tempo em que reconheciam o controle de facto do país. Ademais, os acordos ambicionavam que as instituições estatais e políticas, como as reformas constitucionais e eleições, devolveriam a autoridade soberana para o governo e o povo, distanciando a influência das armas."
\end{abstract}

Mais especificamente, em assuntos referentes à segurança interna do novo governo, os acordos requeriam que todos os grupos armados deveriam se submeter à autoridade interina, para posterior reorganização e formação de um exército nacional. Em segundo lugar, os acordos pediam o auxílio da comunidade internacional para o treinamento do exército e da polícia vindouras, assim como a criação de uma força internacional para assistir a manutenção da segurança de Cabul e de suas redondezas. Por fim, os participantes do encontro pediam que todas as unidades militares deixassem 
Kabul e as demais áreas onde as tropas sancionadas pela ONU fossem enviadas.

Os objetivos delineados em Bonn eram ambiciosos uma vez que a situação no Afeganistão era crítica desde o período da invasão soviética e demandava uma grande atenção da comunidade internacional. Entretanto, se o diagnóstico foi pertinente com a realidade do país, os meios para a sua consecução deixaram a desejar. Segundo Thier (2004), Bonn deu as diretrizes para a reconstrução, delineando leis e instituições que deveriam controlar o país; porém, não procurou dar os detalhes de como as decisões deveriam ser cobradas e levadas adiante. Em que momento e como se daria o desarmamento e integração dos grupos armados? Quais os poderes que as Loya Jirgas Emergenciais e Constitucionais teriam? Como punir aqueles que transgredissem as regras? Ao não refletir sobre tais questões, pelo menos a priori as soluções encontradas para estas interrogações foram todas dadas casuisticamente, sem respaldo jurídico.

Os EUA, a ONU e a comunidade internacional, numa luz de sensibilidade, fizeram uso da Loya Jirga para angariarem apoio aos acordos firmados em Bonn. Assembléia Geral, numa tradução literal, a Loya Jirga foi um mecanismo bastante utilizado na história do Afeganistão, sempre em que se demandavam decisões para assuntos importantes, e que costumava ter 0 respaldo da população ${ }^{115}$. Conforme Fukuyama (2007b), foi uma tentativa em angariar legitimidade para a instalação de um novo governo no país, num processo extremamente influenciado por atores alheios à realidade afegã. Não obstante, as mesmas Loya Jirgas que procuraram lidar com problemas relativos à legitimidade do novo processo político não tocaram na representação étnica que, apesar da concordância Tajik em indicar Hamid Karzai, um Pashtun, para comandar a Autoridade Interina, dificultava a aceitação do novo governo pela maioria da população.

\footnotetext{
${ }^{115}$ Foram 15 Loya Jirgas no Afeganistão. A primeira, em 1747, foi utilizada para legitimar o governo de Ahmad Shah, e era majoritariamente composta por Pashtuns. No decorrer da história do país, outras foram realizadas para se lidar com questões como o posicionamento vis-à-vis a Segunda Guerra Mundial ou mesmo se o país deveria se unir a Índia ou ao Paquistão, após a independência indiana em 1947. Para maiores detalhes, o estudo seminal sobre a história do Afeganistão é Dupree (2002).
} 


\subsection{DE BONN A CABUL}

Bonn apontou quais as diretrizes a operação de Nation-Building deveria seguir: o Afeganistão deveria tornar-se um Estado democrático de direito em um espaço relativamente curto de tempo. Do final de 2001 até 2005 a missão do país era aprovar uma nova Constituição e realizar eleições executivas e legislativas. No entanto, para que as metas fossem atingidas fazia-se necessário a superação de desafios que podiam ameaçar o futuro do país. No que tange aos percalços humanitários, o Afeganistão tinha a maior população de refugiados do mundo, que, ao final de 2001, contabilizava 4,5 milhões, segundo Dobbins et al (2003), além de um grande contingente de pessoas internamente dispersas. Além disso, a infra-estrutura do país encontrava-se em frangalhos assim como os serviços públicos que o governo outrora provia à população. Outrossim, a priori, a presença internacional concentrou-se em Kabul, deixando outras regiões abandonadas e sob o controle dos Senhores da Guerra (Warlords).

Grave era também a situação da economia afegã. Mais de 20 anos de conflito dificultaram sobremaneira a expansão da economia formal do país; porém, por outro lado, criou-se uma economia de guerra que alimenta e é alimentada pela conjuntura regional. Segundo Rubin (2000: 1790-1791):

"Esta economia se desenvolveu em resposta às demandas dos Senhores da Guerra por recursos e da população afegã para sobreviver em um país devastado por mais de 20 anos de guerra. (...) A economia ilícita não está confinada ao Afeganistão. Por meio do desenvolvimento de uma diáspora afegã ligada às sociedades vizinhas, a abertura das fronteiras e a falta de fiscalização aduaneira em várias áreas, a economia de guerra do Afeganistão gerou um padrão de atividade econômica regional que compete e ameaça as economias legais e estatais. Esta economia regional está também ligada ao tráfico de armas e drogas globalizado."

Cramer e Goodhand (2002) também apontam o problema da economia de guerra ao sublinharem a importância dos empreendedores de guerra que, no caso do Afeganistão, exploram as oportunidades econômicas 
oriundas do comércio de armas e drogas ilícitas, que só tendem a aumentar uma vez que o Estado ainda não é forte o bastante para combatê-las. Com o capital necessário para continuarem suas incursões, os Senhores da Guerra não têm incentivo algum para se desarmarem e se submeterem à autoridade estatal. Além dos desafios de uma economia informal e ilegal, a ausência de uma moeda estável fez com que diversos Senhores da Guerra criassem as suas próprias. Entrementes, as principais instituições econômicas de um país um banco central, tesouro público e um ministério de finanças com capacidade extrativa - ou eram fracas demais ou cessaram seu funcionamento.

Ainda segundo Dobbins et al (2003), com relação à segurança interna, os principais empecilhos eram os resíduos do Talibã e da Al Qaeda, principalmente nas províncias do sul e sudeste do país; as ondas de banditismo que assolavam o território depois do colapso do Talibã; e as tensões entre os Senhores da Guerra, os quais, ao menos nominalmente, estavam sob a autoridade do novo governo interino, mas que não deixaram de controlar as suas milícias armadas.

Em um contexto em que as tarefas não se resumiam a apenas um cessar-fogo entre as partes, os EUA optaram por uma abordagem diferenciada, que Dobbins et al (2003) chamam de Small Footprint. Esta nova abordagem consistia em contingentes menores, pois se temia a xenofobia afegã diante das tropas estrangeiras, além de se procurar uma postura distinta da administração Clinton, na qual as operações de Nation-Building tinham contingentes maiores. Ademais, o governo George W. Bush, conforme Dobbins et al (2003) e Daalder e Lindsay (2003), visualizava o Afeganistão como o primeiro estágio de uma guerra mais ampla contra o terrorismo internacional e, portanto, não queria comprometer uma parcela substancial dos seus soldados no país.

Assim sendo, as Forças da Coalizão (Coaltion Forces - CF), contingente liderado pelos EUA e que inicialmente enviou cerca de 8.000 soldados, tinham como meta capturar os resíduos do Talibã e Al Qaeda que ainda se encontravam no país e realizar operações de contra-terrorismo. Por outro lado, estabelecida pela Resolução 1386 do Conselho de Segurança da 
ONU, a International Security Assistance Force (ISAF) ${ }^{116}$, inicialmente com um contingente de 5.000 soldados, tinha como diretriz principal garantir a segurança da capital do país e de seus arredores enquanto a Coalition Forces garantiria o restante do território. Em 2004, a OTAN (Organização do Tratado do Atlântico Norte) tomou a liderança da operação, tornando-se a sua primeira missão fora do continente europeu.

Para auxiliar na construção da capacidade institucional que o país demandava para prover os serviços públicos mais básicos assim como para atingir os objetivos delineados em Bonn, a Resolução 1401 do Conselho de Segurança da ONU estabeleceu a United Nations Assistance Mission in Afghanistan (UNAMA), que deveria integrar todas as atividades das Nações Unidas no Afeganistão. No decorrer de sua existência, o mandato da UNAMA foi gradualmente estendido e ampliado: inicialmente sua principal função era coordenar toda a atividade humanitária; já em 2007, dentre suas tarefas estavam a resolução de conflitos nas províncias além de outras funções como opinar na composição da polícia nacional para impedir que criminosos de guerra fizessem parte da força e na reforma do Ministério do Interior.

Com relação aos recursos financeiros, além das doações individuais dos países que integram a missão, foram realizadas duas importantes conferências para captação de doações. Durante a primeira, realizada em Tóquio ${ }^{117}$ entre os dias 21 e 22 de janeiro de 2002, a estimativa era de que durante os próximos dez anos o Afeganistão demandaria 15 bilhões de dólares. Dentre os principais doadores, segundo Dobbins et al (2003: 134), estavam os EUA (297 milhões de dólares em 2002); Japão (500 milhões durante 30 meses); União Européia (500 milhões em 2002); Arábia Saudita (220 milhões durante 3 anos); e o Banco Mundial (500 milhões durante 30 meses). A segunda conferência, realizada em Berlim entre 30 de março e 01 de abril de 2004, traçou novas estimativas para a recuperação afegã, aumentando o montante necessário para 27.4 bilhões de dólares durante os próximos sete anos. Ademais, vale frisar que inúmeras ONGs também se

\footnotetext{
${ }^{116}$ É necessário salientar que a ISAF é uma missão multinacional autorizada pela ONU, e não uma Operação de Paz. Isto tem implicações importantes porquanto em Operações de Paz a ONU arca com os custos da mesma. Por outro lado, missões multinacionais como a ISAF têm seus custos bancados pelos países membros da operação.

${ }^{117} \mathrm{Em}$ fevereiro de 2003 foi realizada outra conferência em Tóquio para discutir a reforma do setor de segurança do país.
} 
engajaram no processo de reconstrução do país, provendo serviços de ajuda humanitária e econômica para as populações mais carentes.

\subsection{AVANÇOS E RETROCESSOS}

Os Acordos de Bonn formalmente expiraram em setembro de 2005, após a eleição para o Legislativo e para as províncias afegãs. O Executivo é composto pelo Presidente, dois Vice-Presidentes, o AdvogadoGeral e 25 ministros. A eleição presidencial, segundo a Constituição, deve ser realizada a cada cinco anos e o presidente pode exercer dois mandatos seguidos. A Assembléia Nacional encerra duas casas, a Wolesi Jirga (Casa do Povo), cujos membros são eleitos para um período de cinco anos e com 250 assentos; e a Meshrano Jirga (Casa dos Anciãos), com 102 membros, escolhidos pelo presidente e por eleições indiretas. Ademais, ainda temos os Conselhos Provinciais, com número de membros variando entre 9 e 29 pessoas, e os Conselhos Distritais, com 5 até 15 membros, números proporcionais ao tamanho de suas populações. Numa tentativa de tentar rever o problema de representação no governo que outrora minava a confiança da administração Karzai principalmente entre os Pashtun, novos ministros não alinhados com a Aliança do Norte foram nomeados.

Inegáveis são os avanços alcançados pelo Afeganistão após mais de 6 anos de Nation-Building. Mais inegáveis ainda se tornam quando comparados ao período anterior, no qual o Talibã ditava as regras. Hoje é possível reencontrarmos mulheres freqüentando colégios e universidades, além daquelas que voltaram a trabalhar fora de casa. Também é de fácil constatação o número crescente de refugiados que retornaram ao país, além das estradas em reconstrução e das linhas telefônicas, em especial os celulares, funcionando nas áreas urbanas do país. Ao mesmo tempo em que os avanços saltam aos olhos, antigos e novos desafios ainda caminham pari passu à reconstrução. Em janeiro de 2006, durante uma conferência em Londres, foi lançado o Afghanistan Compact, um relatório cuja meta é coordenar os esforços afegãos e internacionais para a reconstrução do país para os próximos 5 anos, substituindo os Acordos de Bonn e focando-se 
principalmente em três grandes áreas: Segurança; governança, direitos humanos e Estado de Direito; e Desenvolvimento econômico e social.

Assim sendo, no primeiro capítulo do presente trabalho, salientamos o fato de que, conforme muito bem apontado por Elias (1993) e Tilly (1996), a consolidação e sobrevivência de um Estado demandam a monopolização e coordenação por parte do governo das capacidades coercitivas, administrativas e extrativas existentes no território. A partir do momento em que este processo de monopolização se consolida em um território, o Estado garante a sua primazia perante as demais instituições. Dessa forma, tendo-se em mente os investimentos feitos no país pela comunidade internacional e as diretrizes dadas pela teoria, podemos enfim fazer um breve balanço da operação de Nation-Building, mostrando seus avanços e possíveis retrocessos, focando principalmente a segurança e a economia do Afeganistão. Comungamos da opinião de Cramer e Goodhand (2002: 904-905):

\begin{abstract}
"O Afeganistão precisa de um Estado efetivo, confiável e centralizado para acelerar o desenvolvimento econômico e reduzir a pobreza, para consolidar a paz e para reduzir os extremos de brutalidade e exploração nas relações econômicas e sociais. As políticas fiscais e regulatórias que estarão envolvidas significam que um Estado é mais do que um exercício de construção de capacidades institucionais: é inevitavelmente um exercício político e certamente gerará conflitos. A credibilidade do processo de reconstrução do Estado dependerá no potencial coercitivo do Afeganistão: o governo precisará monopolizar os meios de coerção. (...) Sem um Estado forte e centralizado, uma economia ilegal de guerra se tornará meramente uma economia ilegal de paz."
\end{abstract}

\title{
5.3.1. SEGURANÇA
}

A segurança certamente é o ponto mais crítico da reconstrução afegã. Um contingente menor de soldados norte-americanos no Afeganistão assim como a restrição inicial à expansão da ISAF para o restante do território fez com que a ampliação do espectro de segurança se restringisse a Cabul. 
Em termos comparativos, enquanto na Bósnia havia 18.6 soldados para mil pessoas e em Kosovo 20 para cada mil, no Afeganistão a cifra gira ao redor de 0.18 soldados para cada mil pessoas, segundo Dobbins et al (2003: 136). Para piorar ainda mais a situação, a Autoridade de Transição, por ainda não poder contar com um exército próprio, foi obrigada a negociar com os Senhores da Guerra e suas milícias particulares para expandirem a autoridade do governo pelos demais quinhões de território. Todavia, muitas vezes não era interessante para uma facção submeter-se ao governo uma vez que não receberiam as mesmas receitas que aquelas oriundas da economia de guerra, além da perda de capital político ao entregar as armas para uma autoridade superior.

Destarte, em fevereiro de 2003 foram anunciadas as diretrizes da Reforma do Setor de Segurança (Security Sector Reform) as quais ambicionavam dirimir os problemas supracitados. Em seu bojo, a reforma demandava o estabelecimento de cinco pilares: (1) a criação de um Exército Nacional Afegão (Afghan National Army - ANA); (2) a criação de uma Polícia Nacional Afegã (Afghan National Police - ANP); (3) a reforma do Judiciário; (4) o desarmamento, desmobilização e reintegração das milícias armadas; e (5) uma política de Contra-Narcóticos. Para liderar as reformas, os EUA se encarregaram do treinamento do exército; a Alemanha, da polícia; a reforma do Judiciário ficou a cargo da Itália; o desarmamento, desmobilização e reintegração a cargo do Japão; e o combate aos narcóticos, tarefa da Inglaterra.

Os resultados da reforma são um tanto quanto díspares. Conforme Jalali (2007), a reforma do Judiciário sofre de falta de recursos humanos e de infra-estrutura. Os juízes ainda não estão adequadamente treinados e a corrupção ainda é um mal a ser combatido. Com relação ao desarmamento, desmobilização e reintegração, o processo foi formalmente encerrado em junho de 2006. Segundo cômputos levantados pelo Afghanistan Research and Evaluation Unit de fevereiro de 2008, 63.380 ex-soldados e oficiais foram desarmados e, deste montante, 55.804 optaram por algum dos programas de reintegração, os quais incluíam treinamentos vocacionais, treinamento para agricultura e oportunidades de emprego. A política de ContraNarcóticos, principalmente aquelas endereçadas ao cultivo de ópio ainda 
enfrentam dificuldades substanciais, visto que, segundo o relatório de abril de 2008 da United Nations Office on Drugs and Crime (UNDOC), no último ano houve um aumento de $34 \%$ da produção de ópio no país, assim como das terras destinadas a este cultivo. $O$ resultado é que hoje a produção afegã corresponde a $93 \%$ da produção global de ópio. Os efeitos do ópio no Afeganistão serão tratados na seção ulterior, sobre a reconstrução econômica.

Por sua vez, o exército afegão foi estabelecido em 2003 e tinha como objetivos preservar as fronteiras e proteger o país de ameaças externas; derrotar as forças terroristas; e combater os grupos armados. Em outubro de 2007, segundo o Afghanistan Research and Evaluation Unit (2008), o exército possuía ao redor de 55.000 soldados, cifra que deveria chegar a 70.000 até o final de 2008. Para garantir diversidade geográfica e étnica, centros de recrutamento estão presentes em cada uma das 34 províncias do país. Todavia, conforme Jalali (2007), o exército sofre de falta de armamentos e de suporte aéreo além da ausência de um orçamento que cubra as suas despesas, culminando em uma contínua dependência das Forças da Coalizão e da ISAF.

Conforme salientado no primeiro capítulo, a pacificação interna é condição sine qua non para a consolidação do Estado e de uma economia capitalista. Logo, um exército e uma força policial são variáveis extremamente importantes para esta tarefa: enquanto o exército se responsabilizaria pela manutenção da integridade territorial e pela defesa contra ameaças externas, ao cargo da polícia estaria evitar conflitos internos e punir aqueles que infringissem o ordenamento imposto pelo Estado (GIDDENS, 2001). Contudo, no caso do Afeganistão, por estar enquadrado na Guerra ao Terrorismo dos EUA e por ser treinado pelas forças norte-americanas, o desenvolvimento de um exército nacional recebeu prioridade, em detrimento da força policial. Os soldados vêm recebendo treinamento principalmente para contra-insurgência e combate aos grupos terroristas, metas que talvez fossem mais bem aproveitadas pela polícia nacional. Treinada inicialmente pela Alemanha e agora pela União Européia, a polícia está à frente do combate ao tráfico ilegal de drogas no país, crime organizado e grupos terroristas. Com uma meta de recrutar 62.000 membros até 2010, a polícia vem sofrendo mais baixas que 0 
exército uma vez que a insurgência ataca principalmente dentro das cidades e com apoio da população.

Em uma tentativa de atingir as províncias mais além de Cabul, as Forças da Coalizão criaram as Equipes de Reconstrução Provincial, unidades pequenas (em torno de 100 a 250 pessoas) compostas por militares e civis para facilitar o desenvolvimento do processo de reconstrução. Os militares provêm segurança para os civis que, por meio de sua composição - que vai desde representantes dos países doadores até conselheiros para agricultura e veterinária e responsáveis pelo treinamento policial - procuram ajudar a República Islâmica do Afeganistão a estender sua autoridade para facilitar o desenvolvimento de um ambiente de segurança (AFGHANISTAN RESEARCH AND EVALUATION UNIT, 2008: 44). Para auxiliar a expansão da autoridade do governo, a partir de 2003 a ISAF foi autorizada a ampliar suas atividades para além de Kabul e atingir as provinciais mais longínquas. Até outubro de 2007, a ISAF contava com 33.000 soldados no Afeganistão enquanto as Forças de Coalizão mantinham um contingente de 8.000 militares.

Esta preocupação em estender a autoridade do governo central para além de Cabul tem por fundamento evitar o fortalecimento dos movimentos de insurgência, em especial o retorno do Talibã, certamente um dos principais desafios no campo da segurança. Segundo o Relatório do Secretário-Geral da ONU de 06/03/2008, muitos distritos no leste, sudeste e sul do país continuam inacessíveis aos oficiais afegãos e à ajuda humanitária e continuam sob controle do Talibã. Conforme salientado por Karzai (2007), diversos fatores auxiliaram no renascimento do Talibã, dentre os quais se destacam: (1) o apoio logístico vindo de fora, principalmente aquele fornecido nas fronteiras com o Paquistão; (2) o retorno de combatentes que estavam em outros países, e (3) os lucros obtidos no tráfico de drogas. De uma milícia armada que tomou o país e controlou mais de $90 \%$ do território, o Talibã hoje atua de forma descentralizada, de maneira similar aos grupos terroristas, com células em diversas cidades e províncias. A insurgência Talibã teve início em 2002, com ataques nas províncias do Sul até alcançaram Cabul. Segundo Jones (2008), a onda de violência foi extremamente aguda entre 2005 e 2006, com o número de ataques suicidas subindo de 27 para 139 e ataques armados atingindo o montante de 4.542. $\mathrm{O}$ ano de 2007 foi o de maiores baixas para os 
EUA desde 2001, com 117 mortos $^{118}$. Conforme muito bem apontado por Rubin (2007), se Washington quer realmente findar com a insurgência Talibã, deve voltar suas atenções para a fronteira com o Paquistão, região na qual a milícia encontra refúgio e campos de treinamento para seus militantes. Ainda segundo Rubin (2007), o principal quartel-general do Talibã localiza-se em Quetta e existem fortes rumores de que o Paquistão provê ajuda para as lideranças ali presentes.

As saídas para contenção e extermínio dos resíduos do Talibã e da Al Qaeda ${ }^{119}$ são conhecidos. Jones (2008) afirma que estas milícias prosperaram devido à existência de um governo fraco que não consegue prover serviços para a sua população e, neste vácuo, substituíram a autoridade estatal. Logo, uma das formas de se findar com a ameaça colocada pelo movimento insurgente, além do aumento da força policial e de maiores tropas estrangeiras no país, é a ampliação do espectro do Estado para as províncias do país, podendo assim substituir o papel que até o presente momento é realizado pelos Senhores da Guerra e pelo Talibã. Para tanto, não bastam medidas de segurança; a economia precisa também ser levada em consideração e é para ela que nos voltamos agora.

\subsubsection{ECONOMIA}

É praticamente consensual entre os autores que, para se firmar enquanto um Estado perante sua população, o Afeganistão precisa prover bens públicos, tais como segurança, infra-estrutura, saúde e educação, não apenas em Cabul, mas em todas as 34 províncias do país. Não obstante, para que possa desempenhar estas tarefas, é imperativo o desenvolvimento de capacidades extrativas; contudo, enquanto estas capacidades continuam embrionárias, ainda são essenciais os aportes financeiros externos.

Desde 2001 o país conseguiu avanços consideráveis. Uma nova moeda, o Afghani, já circula no país, além da criação de um banco central e de

\footnotetext{
118 O número de baixas norte-americanas tanto no Afeganistão como no Iraque está disponível no sítio www.icasualties.org. Acesso em 04/05/2008.

${ }_{119}$ Para maiores detalhes sobre a insurgência no Afeganistão, Jones (2008), Johnson e Mason (2006 e 2008) e Giustozzi (2007).
} 
ministérios das Finanças, Economia, Serviços Públicos, Reabilitação Rural e Desenvolvimento, Comércio e Indústria, entre outros. Além disso, foi criado o Orçamento Nacional do Afeganistão (Afghanistan's National Budget), constituído pelo Orçamento Central (Core Budget) e o Orçamento Externo (External Budget). Enquanto o primeiro incluí todos os fundos sobre os quais o governo tem controle direto e são manejados pelo Tesouro Nacional, o último se refere a todas as rendas que são reportadas mas não controladas pelo governo - são os fundos direcionados diretamente dos doadores para seus enviados no Afeganistão. Com relação ao Orçamento Central, existem duas linhas de execução de gastos: há o Orçamento para Desenvolvimento, utilizado para investimentos; e o Orçamento Ordinário, utilizado para pagamentos dos salários e das operações administrativas.

Segundo dados do Banco Mundial de 2005, a economia afegã cresceu fortemente em 2003 e 2004, com um aumento cumulativo do PIB, excluídas as rendas oriundas do cultivo do ópio, de quase $50 \%$. Ademais, com a melhoria da situação econômica e política, até 20052.4 milhões de refugiados haviam retornado ao país. Serviços sociais, como educação primária e imunização deram seus primeiros passos e já alcançam porções consideráveis da população, ainda que a mortalidade infantil no país seja de 115 por mil nascidos (BANCO MUNDIAL, 2005) e o saneamento básico ainda seja precário.

Desafios, no entanto, ainda perduram e dois merecem um melhor escrutínio porquanto colocam grandes obstáculos para a reconstrução do Estado. O primeiro deles é o papel desempenhado pela assistência internacional. Conforme destacado no segundo capítulo, a dependência afegã dos aportes externos é uma constante na história do país: desde o período em que se caracterizava como um Estado tampão entre a Rússia czarista e a Inglaterra, passando pela Guerra Fria e chegando à atual conjuntura, o Estado afegão é um dependente crônico da ajuda internacional. Dentre os motivadores para tal desenvolvimento destaca-se o difícil relacionamento entre Estado e sociedade no país, tornando-se mais fácil pedir auxílios externos do que tentar desenvolver capacidades extrativas e entrar em um embate direto com a população. A maior parte dos governantes que tentaram desenvolver tal 
capacidade não logrou êxito e, por conseguinte, retornaram à dependência externa.

Até o meio de 2003, conforme os dados de Goodson (2007), pelo menos 3.000 ONGs nacionais e internacionais operavam no Afeganistão, principalmente na redução da pobreza, educação e saúde, além dos esforços do governo central, da UNAMA e de outras 16 agências da ONU e da USAID. Enxergando o governo central como intrusivo e corrupto, boa parte delas optou por um distanciamento da administração Karzai, tratando diretamente com a população mais carente. Pela ótica do Estado, o provimento desses serviços pelas ONGs compromete a administração governamental visto que, perante a população, fica a impressão de que quem está realmente fazendo alguma coisa não é o governo. Conforme apontado por Starr (2007: 116):

\footnotetext{
"O governo, vendo sua legitimidade ser minada, requisitou à comunidade internacional que toda a ajuda financeira fosse enviada por meio da administração civil ao invés das ONGs, argumentando que tal controle é um exercício de soberania. Ashraf Ghani, em seu papel como ministro das finanças, foi particularmente assertivo neste ponto. Infelizmente, a comunidade internacional, argumentando que a prática era pouco eficaz e que deveria ser promovido o desenvolvimento de uma sociedade civil - a despeito da ausência de instituições formais estatais - ingenuamente e irresponsavelmente deixou de lado as preocupações com a reconstrução do Estado."
}

Mesmo com os argumentos do ministro do Planejamento Ramazan Bashar Dost, em abril de 2004 durante a conferência dos doadores em Berlim, de que a ajuda financeira via ONGs faria mais mal do que bem para o Afeganistão a maior parte destas entidades não compreenderam o fato de que seu trabalho, ainda que deveras importante, ameaçava a administração local perante a sociedade, uma vez que a entrega dos bens públicos é o desafio fundamental para o governo testar sua legitimidade e angariar apoio em todo o território. Chesterman (2002) argumenta que esta postura por parte das ONGs e dos doadores é uma faca de dois gumes: ao mesmo tempo em que alegam que o governo e instituições como o Banco Mundial e o PNUD são extremamente lentos na execução das tarefas - o que não deixa de ter um 
fundo de verdade - todos querem ter seus nomes ligados ao processo de reconstrução, pois estas ações garantem visibilidade internacional. Ainda segundo o autor, todos querem mandar crianças de volta para os colégios; por outro lado, ninguém quer pagar os salários dos militares (CHESTERMAN, 2002: 42).

Um último ponto sobre a ajuda externa deve ser sublinhado. Tendo-se em mente que os recursos humanos qualificados no Afeganistão ainda são exíguos, as disparidades salariais dificultam o recrutamento de mãode-obra para o governo. Segundo dados de 2002, a média do salário mensal pago pelo governo afegão girava em torno de 28 dólares, montante que sobe para 40 dólares para os ministros e 80 dólares para os juízes. No outro extremo, um afegão trabalhando para uma ONG ganha 15 ou até 400 vezes mais que este valor (CHESTERMAN, 2002). Estas diferenças criam problemas consideráveis, pois muitas pessoas preferem deixar seus cargos no alto escalão governamental para trabalhar como motoristas ou mesmo como segurança, ainda que sejam empregos temporários.

O segundo desafio para a reconstrução econômica do Afeganistão é aquele apresentado pelo ópio. Iniciado ao final da década de 1970, com o objetivo de criar um problema com drogas entre os invasores soviéticos, da mesma forma que os soldados norte-americanos enfrentaram problemas com o abuso de narcóticos durante a Guerra do Vietnã (FAZEY, 2007), o cultivo de ópio envolve aproximadamente 2 milhões de pessoas, presente tanto em latifúndios quanto em pequenas propriedades. Em 2003, segundo dados do Banco Mundial (2005), a renda oriunda do cultivo e tráfico de ópio representava $1 / 3$ do PIB do Afeganistão ${ }^{120}$. Segundo a figura abaixo, do relatório da United Nations Office on Drugs and Crime de abril de 2008 (UNDOC, 2008: 08), temos a seguinte evolução do cultivo do ópio, em hectares cultivados:

\footnotetext{
${ }^{120}$ Entretanto, há de se salientar que existe também a produção legal de ópio, destinada à produção de morfina, heroína, entre outros anestésicos para procedimentos médicos.
} 
Figure 1: Opium Poppy Cultivation in Afghanistan (ha), 1990-2007.

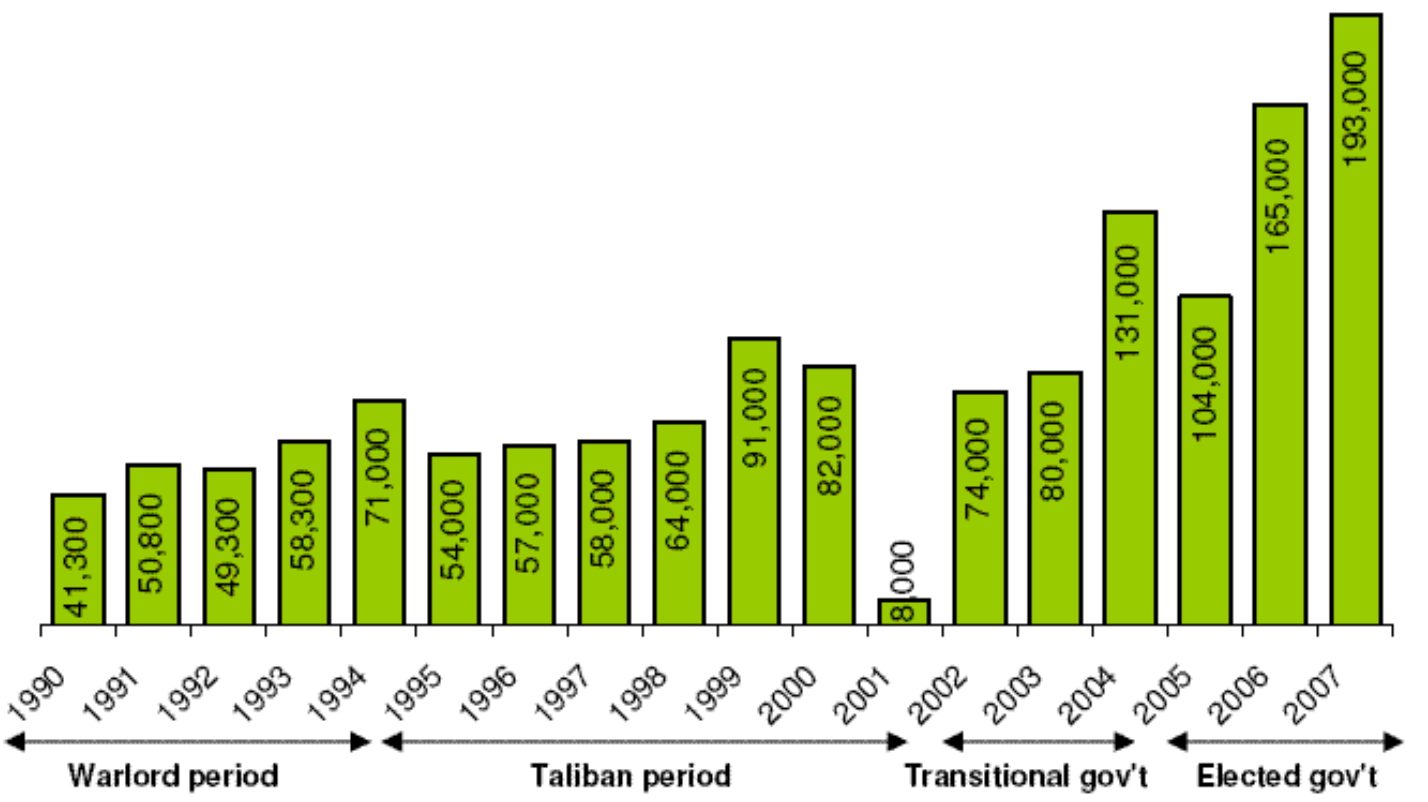

Source: UNODC, Afghanistan Opium Survey 2007, October 2007

Além de alimentar uma rede internacional de tráfico de drogas ${ }^{121}$, o cultivo ilegal de ópio no Afeganistão prejudica enormemente 0 estabelecimento de uma economia formal no país, a qual é passível de ser taxada pelo Estado e, consequentemente, garantir renda para a execução dos serviços públicos. Ademais, os lucros oriundos da produção e do tráfico alimentam os cofres dos Senhores da Guerra e mesmo do Talibã, incrementando a capacidade militar destas milícias. De acordo com o relatório do Banco Mundial (2005: xxiv), a economia política do ópio é caracterizada segundo a tabela abaixo:

121 Segundo o mesmo relatório da UNDOC (2008), existem três rotas para a saída do ópio afegão: a primeira é pela Ásia Central; a segunda é pelo Irã; e a terceira pelo Paquistão. $O$ tráfico é facilitado pela ausência de controle governamental em determinadas províncias, pela corrupção existente nos órgãos governamentais; e pela falta de treinamento das autoridades para erradicar o cultivo e punir os produtores e traficantes. 


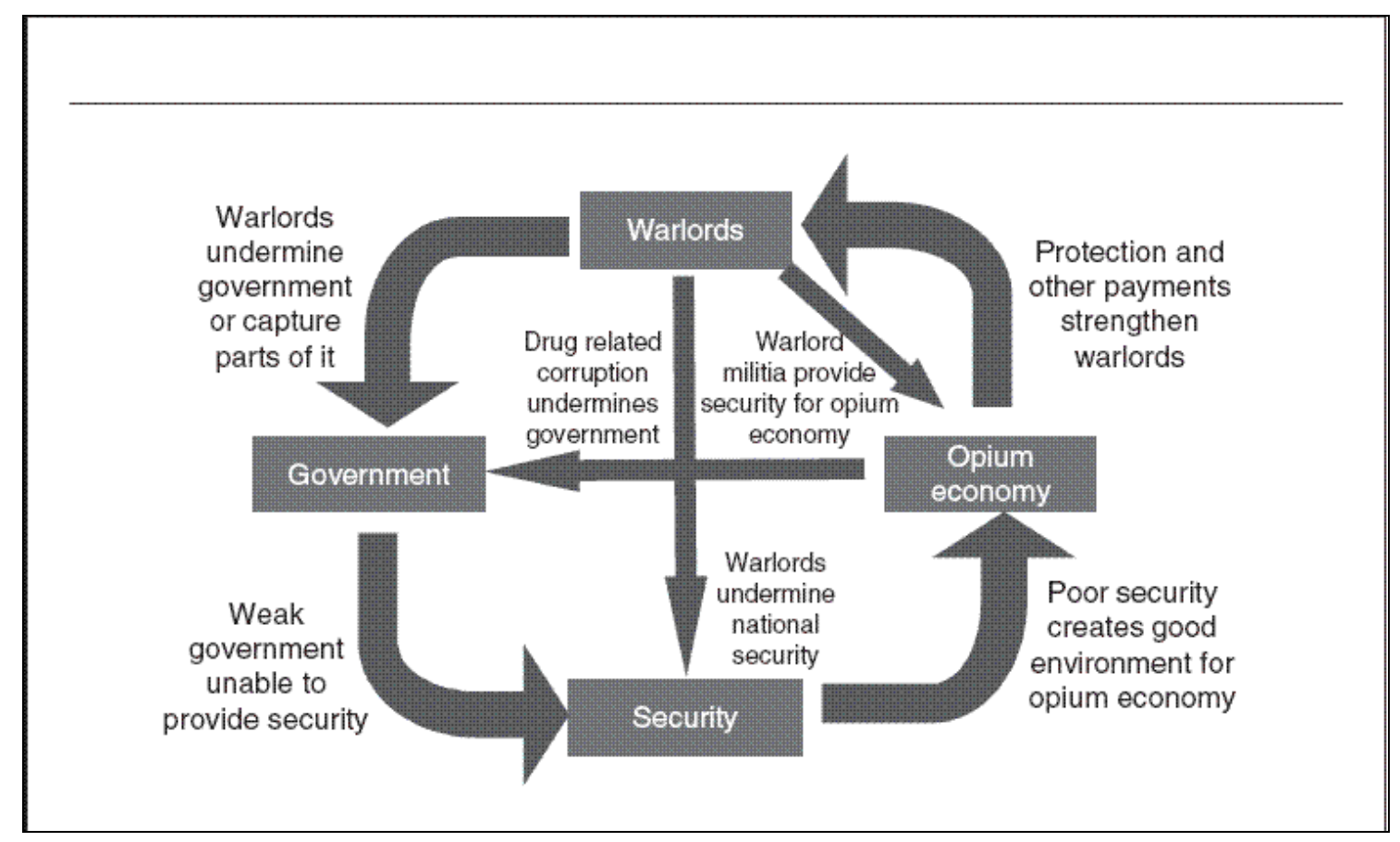

As soluções endereçadas à erradicação do ópio devem ir além da destruição das plantações. O Ministério de Contra-Narcóticos, trabalhando em conjunto com a UNDOC, apresenta três áreas prioritárias, quais sejam, a eliminação dos traficantes; a diversificação das opções de plantio para os agricultores; e o provimento de tratamento para os usuários. Estas ações são essenciais uma vez que a mera eliminação das colheitas acaba com a principal renda dos agricultores e não dá nenhum incentivo para que os mesmos adentrem na economia formal do país. Pior ainda, a erradicação, sem nenhuma outra medida de assistência anterior, tende a levar os indivíduos para o lado dos Senhores da Guerra, uma vez que estes podem prover serviços em áreas em que o Estado ainda é ineficiente. Dessa forma, o combate ao cultivo ilegal de ópio é uma tarefa multidimensional na qual a erradicação deve ser uma das últimas tarefas a serem empreendidas. 


\section{CONSIDERAÇÕES FINAIS}

"A população de um dos países mais pobres do mundo resistiu com sucesso à invasão de uma superpotência. Lutaram por suas vidas num sistema mundial imposto sobre eles. Se a situação no Afeganistão é desesperadora hoje, a culpa não é da sua população. O Afeganistão não é um espelho dos Afegãos: é um espelho do mundo ${ }^{122 " .}$

Enfim chegamos às considerações finais do presente trabalho. Durante todo o percurso anterior, procuramos responder questões que considerávamos importantes; porém, ao tentarmos esclarecer um problema, outros foram surgindo devido à complexidade da situação em estudo, que deverão merecer novas e futuras abordagens. Se conseguirmos ao menos alimentar o corrente debate sobre Estados Falidos e as chamadas Operações de Nation-Building e apresentar novas direções para pesquisas vindouras, damo-nos por satisfeitos. Dessa forma, nos cabe agora salientar os principais pontos levantados durante a pesquisa e indicar quais direções possam tomar as agendas de pesquisa.

$\mathrm{Na}$ primeira parte deste trabalho detivemo-nos na análise do conceito de Estado Falido e destacamos o seu componente comparativo, visto que ele encerra $o$ arquétipo do Estado moderno europeu, democrático e caracterizado pela predominância de uma economia capitalista de mercado. Também concluímos que o conceito se aplica ao caso afegão pois negar que o Afeganistão não apresenta um governo forte e é ineficiente no provimento de bens públicos para a sua população, principalmente após os anos de guerra civil e a queda do Talibã, é ir contra a realidade. Todavia, a despeito do diagnóstico coerente, o conceito de Estado Falido apresenta dois problemas fundamentais que muitas vezes são desconsiderados.

Antes de mais nada, considera-se que o Estado europeu é um modelo acabado e que atingiu o seu zênite. As análises partem do pressuposto de que, para parafrasear Fukuyama (1992), a história realmente chegou ao fim para o Estado; nada superará o Estado democrático-liberal e que este mesmo aparato, fruto de um construto histórico de mais de mil anos,

${ }^{122}$ RUBIN, 2002: vi. 
está finalizado. Ademais, nas mesmas análises, tem-se a impressão de que o Estado foi construído nos países do chamado Terceiro Mundo e que devido a determinadas causas, em sua maioria endógenas, nestas regiões eles não conseguiram se consolidar. Ora, em nenhum momento as análises do mainstream questionam se realmente se formou algum Estado, nos mesmos moldes daqueles originados na Europa, nestes países. Desconsidera-se o processo histórico que levou o Estado do Velho Continente para os demais territórios e como este processo influenciou no surgimento de diferenças qualitativas entre os países.

Quanto às causas do fracasso estatal, discordamos veementemente de boa parte das análises (ROTBERG, 2003 e 2004; FOREIGN POLICY, 2007), as quais adjudicam somente a problemas de governança interna o colapso da autoridade. Por meio do caso do Afeganistão, constatamos que é deveras problemático afirmar que em algum momento de sua história formou-se um Estado nos moldes europeus neste quinhão da Ásia Central; e, pelo mesmo exemplo, é ainda mais difícil afirmar que as causas da falência estão restritas às decisões governamentais inadequadas. A pressão do sistema internacional, associada com a dinâmica interna do país em nenhum momento possibilitou a formação de um Estado moderno no território. Quando os auxílios externos findaram com o final da Guerra Fria, o pequeno aparato governamental não agüentou a pressão interna e se esfacelou. Concordamos com Bilgin e Morton (2002), quando afirmam que nestas análises o Estado é abstraído de seu contexto sócio-histórico e adjetivado enquanto falido vis-à-vis suas capacidades coercivas e o fracasso seria causado por características intrínsecas dos países em questão, sem qualquer reflexão acerca de seu passado colonial e sua posição periférica nas estruturas políticas e econômicas mundiais.

Com relação às Operações de $\mathrm{Paz}$, notamos que, desde a sua criação durante os anos de Guerra Fria, passando pela euforia da década de 1990, até a atual conjuntura de Guerra ao Terrorismo do pós-Onze de setembro de 2001, as mesmas passaram por uma evolução, ocasionada pela nova natureza dos conflitos, os quais hoje são majoritariamente de cunho intraestatal. Assim sendo, como bem diagnosticado por Fonseca Jr. (2006), os processos de intervenção multilateral alteram-se em dois sentidos, uma vez 
que (1) não se trata mais de lidar com Estados soberanos e sim de reconstruir soberanias; e (2) mensurar sucesso ou fracasso não é mais uma questão apenas de evitar a eclosão de um novo conflito: estabilizar estas regiões, além dos esforços militares, demanda também ações de natureza social e econômica.

Mais especificamente sobre as chamadas operações de NationBuilding, notamos um intenso debate, que versa desde a sua definição até a sua caracterização, e no qual o consenso entre as partes não é atingido. Contudo, na análise das operações arroladas por Dobbins et al $(2003,2005)$ e Paris (2004), vemos que o consenso é atingindo no que tange às diretrizes das operações: todas elas são guiadas por uma estratégia em que se privilegiam a realização de eleições e a criação de um ambiente seguro para 0 desenvolvimento de uma economia de mercado. No caso do Afeganistão vimos que os Acordos de Bonn demandavam a formulação e aprovação de uma Constituição e a realização de eleições em um período relativamente curto (2001-2005). Da mesma forma que a gestação do problema envolve a articulação de variáveis internas e externas, a solução precisa também se dar nestes dois níveis, ou seja, as reconstruções de Estado deveriam levar em consideração a dinâmica interna dos países e suas principais necessidades, não apenas um receituário pré-estabelecido e aplicável a todas os países, a despeito de suas singularidades. Não pretendemos fazer nenhum juízo de valor sobre a democracia e o capitalismo enquanto formas de organização política e econômica; porém, o uso político realizado em nome da exportação democrática e do desenvolvimento econômico torna cada vez mais pertinente a pergunta de Ignatieff (2005): para quem são feitas as reconstruções de Estado: para a população do país ou para os líderes políticos do ocidente e para o capitalismo internacional?

Os papéis dos EUA e da ONU nas operações também se destacam com relação ao Nation-Building. De um lado, a principal organização internacional se vê cerceada pelos interesses de seus países membros, mas, apesar das tergiversações dos mesmos, apresentam uma estrutura organizacional capaz de conduzir as missões, ainda que extremamente dependente da contribuição dos Estados. De outro lado, a principal potência mundial apresenta um comportamento oscilante: de patrocinador inicial da 
ONU, os EUA passaram por momentos de um maior afastamento em relação a organização durante a década de 1970, apoiando entusiasticamente as Operações de Paz no início da década de 1990 até uma abordagem que, se no imediato pós-Onze de setembro foi de rejeição, hoje apresenta um viés mais pragmático, conforme evidenciado por Patrick (2008) quando arrola o suporte dos EUA às operações na África. No entanto, o país ainda sofre da carência de uma burocracia especializada para as missões, ainda que possua um extraordinário poder militar e econômico para conduzir as missões, além do fato de que todas as operações bem sucedidas contaram com o suporte norteamericano.

Por fim, procurando evitar prognósticos apressados, cabe-nos apenas indagar, com base nas diretrizes dadas por Elias (1993), Tilly (1996) e Giddens (2001), quais as perspectivas para a reconstrução do Estado afegão. Tendo-se em mente a necessidade de um maior controle sobre os meios coercitivos e as capacidades extrativas para a provisão dos serviços públicos, o Estado no Afeganistão ainda caminha a passos lentos: continua extremamente dependente da assistência externa e sofre com os ataques que a insurgência perpetra no país. Dobbins et al (2003) sublinham o fato de que pouco foi investido e que, portanto, os resultados esperados ainda não serão tão cedo alcançados. Para infortúnio dos afegãos, o país nunca foi uma prioridade para a política externa dos EUA: conforme nos dizem Daalder e Lindsay (2003), o interesse da administração Bush no país era caçar os responsáveis pelos ataques às Torres Gêmeas e ao Pentágono. Segundo palavras do presidente norte-americano (apud DAALDER e LINDSAY, 2003: 112) seria uma função interessante para a ONU assumir o chamado Nation-Building - o que eu prefiro cunhar como estabilização para um novo governo - quando nossa missão militar estiver completa.

Por fim, o que podemos esperar? Com o foco norte-americano no Iraque desde 2003, o Afeganistão ficou relegado a segundo plano, possibilitando o ressurgimento das milícias armadas contrárias à administração Karzai. Grupos terroristas encontram refúgio na fronteira com o Paquistão e o cultivo ilegal de ópio atinge índices recordes. Todas estas variáveis afetam a reconstrução do Afeganistão, país cujas instituições político-administrativas se encontram sumamente fragilizadas e pouco consolidadas. No entanto, para 
que as perspectivas do nascedouro não sejam sufocadas pelo próximo ataque do Talibã ou mesmo pelo poder militar dos Senhores da Guerra financiados pelo tráfico ilegal de drogas, a comunidade internacional não pode uma vez mais relegar esta região ao esquecimento; novos passos precisam ser dados na reconstrução do país para que, na próxima curva da História, este quinhão da Ásia Central, assombrado por intervenções externas e regimes autoritários, possa encontrar alguma paz. 


\section{REFERÊNCIAS BIBLIOGRÁFICAS}

ABERNETHY, David. The Dynamics of Global Dominance: European Overseas Empire, 1415-1980. Yale University Press, 2000.

AFGHANISTAN RESEARCH AND EVALUATION UNIT. The $\mathbf{A}$ to $\mathbf{Z}$ Guide to Afghanistan Assistance. Islamabad: Army Press, 2008.

ALVES, José Augusto Lindgren. Os direitos humanos como tema global. São Paulo: Perspectiva, 2003.

ANDERSON, Perry. Linhagens do Estado Absolutista. São Paulo: Brasiliense, 2004.

ARMSTRONG, Karen. O Islã. Rio de Janeiro: Objetiva, 2001.

. Maomé: Uma biografia do Profeta. São Paulo: Companhia das Letras, 2002.

ARON, Raymond. Paz e Guerra entre as Nações. São Paulo: IOESP, 2002.

AYERBE, Luis Fernando. Estados Unidos e América Latina: A construção da Hegemonia. São Paulo: Unesp, 2002.

. Ordem, Poder e Conflito no século XXI: Esse mesmo mundo é possível. São Paulo: Unesp, 2006.

BALDWIN, David. Neorealism and neoliberalism: the contemporary debate. New York: Columbia University Press, 1993.

BANCO MUNDIAL. Afghanistan: State-Building, Sustaining Growth, and Reducing Poverty. Washington: World Bank, 2005. 
BARNETT, Michael e FINNEMORE, Martha. Rules for the World: International Organizations in Global Politics. New York: Cornell University Press, 2004.

BELLAMY, Alex et al. Understanding Peacekeeping. Cambridge: Polity Press, 2004.

BENNER, Thomas et al. Learning to Build Peace? United Nations Peacebuilding and Organizational Learning: Developing a Research Framework. Berlin: Global Public Policy Institute, 2007.

BENSAHEL, Nora. Organising for Nation Building. Survival, vol. 49, n. 2, p.p 43-76.

BILGIN, Pinar e MORTON, Adam. Historicising representations of 'failed states': beyond the cold-war annexation of the social sciences? Third World Quarterly, vol. 23, n. 01 , p.p. 55-80.

BOBBIO, Norberto. A Era dos Direitos. Rio de Janeiro: Campus, 2004.

BOOTH, Ken. Critical Security Studies and World Politics. London: Lynner Rienner, 2004.

BRAHIMI, Lakhdar. Report of the Panel on United Nations Peace Operations. New York: General Assembly and Security Council, 2000.

BRIGADÃO, Clóvis e MELLO, Valerie de Campos. Diplomacia cidadã: Panorama Brasileiro de Prevenção de Conflitos Internacionais. Rio de Janeiro: Gramma, 2006.

BROWN, Michael et al. America's Strategic Choices. London; The MIT Press, 2001.

BULL, Hedley. A Sociedade Anárquica. São Paulo: IOESP, 2002. 
BUSH, George H. Toward a New World Order. Discurso Proferido diante o congresso norte-americano. Washington: White House, 1990.

BUSH, George W. A Estratégia de Segurança Nacional dos EUA. Política externa, vol. 11, n.03, dez/jan/fev. 2002/2003.

. The National Security Strategy of the United States of America. Washington: White House, 2006.

BUZAN, Barry. New Patterns of Global Security in the Twenty-First Century. International Affairs, Vol.67, No. 03, p.p. 431-451, 1991a

People, States and Fear: an agenda for international security studies in the post-Cold War era. Londres: Harvester Wheatsheaf, 1991b

BUZAN, Barry e LITTLE, Richard. International Systems in World History: Remaking the Study of International Relations. Oxford: Oxford University Press, 2000.

CARR, Edward. Vinte Anos de Crise. São Paulo: IOESP, 2002.

CARVALHO, Maria Izabel e SANTOS, Maria Helena. O Século 21 no Brasil e no Mundo. São Paulo: EDUSC, 2006.

CHESTERMAN, Simon. Walking Softly in Afghanistan: the future of UN StateBuilding. Survival, vol. 44, n. 3, p.p. 37-46, 2002.

CHESTERMAN, Simon et al. Making States Work. New York: United Nations Press, 2005.

CLÉMENT, Caty. Nuts and Bolts of State Collapse: Common Causes and Different Patterns. COMPASSS Working Paper, 2005. 
COLL, Steve. Ghost Wars: the secret history of the CIA, Afghanistan, and Bin Laden, from the soviet invasion to September, 10, 2001. New York: Penguin Books, 2004.

COLLIER, Paul e HOEFFLER, Anke. The Challenge of Reducing the Global Incidence of Civil Wars. Oxford: Oxford University Press, 2004.

COX, Robert W. Social Forces, States and World Orders: Beyond International Relations Theory. In: KEOHANE, Robert. Neorealism and its Critics. New York: Columbia University Press, 1986.

CRAMER, Christopher e GOODHAND, Jonathan. Try Again, Fail Again, Fail Better? War, the State, and the 'Post-Conflict' Challenge in Afghanistan. Development and Change, vol. 33, n. 5, p.p. 885-909.

CREVELD, Martin. Ascensão e Declínio do Estado. São Paulo: Martins Fontes, 2004.

CRISIS STATES RESEARCH CENTER. Crisis, Fragile and Failed States: Definitions used by CSRC. London: Crisis States Workshop, 2006.

DAALDER, Ivo. Knowing when to say No: The Development of US Policy for Peacekeeping. In: DURCH, William. UN Peacekeeping, American Policy, and the uncivil wars of the 1990s. New York: St. Martin's Press, 1996.

DAALDER, Ivo e LINDSAY, James. America Unbound: The Bush revolution in foreign policy. Washington: Brookings Institution, 2003.

DAHL, Robert. Who governs? Democracy and Power in an American City. New Haven: Yale University Press, 1961.

DEMANT, Peter. O Mundo Muçulmano. São Paulo: Contexto, 2004. 
DOBBINS, James. Nation-Building: The Inescapable Responsibility of the World's Only Superpower. Rand Review, vol. 27, n. 2, p.p. 16-27, 2003.

DOBBINS, James et al. America's Role in Nation-Building: From Germany to Iraq. Santa Monica: Rand, 2003.

UN's Role in Nation Building: From Congo to Iraq. Santa Monica: Rand, 2005.

Beginner's Guide to Nation-Building. Santa Monica: Rand, 2007.

DONINI, Antonio et al. Nation-Building Unraveled? Aid, Peace and Justice in Afghanistan. Bloomfield: Kumarian Press, 2004.

DOYLE, Michael e SAMBANIS, International Peacebuilding: a Theoretical and Quantitative Analysis. IN: AMERICAN POLITICAL SCIENCE ASSOCIATION, 2000.

DUPPRE, Louis. Afghanistan. Oxford: Oxford University Press, 2002.

DURCH, William. Keeping the Peace: Politics and Lessons of the 1990's. In: DURCH, William. UN Peacekeeping, American Policy, and the uncivil wars of the 1990s. New York: St. Martin's Press, 1996.

DURCH, William. UN Peacekeeping, American Policy, and the uncivil wars of the 1990s. New York: St. Martin's Press, 1996 b.

EINSIEDEL, Sebastian. Policy responses to State Failure. In. CHESTERMAN, Simon et al. Making States Work. New York: United Nations Press, 2005.

EKBLADH, David. From Consensus to Crisis: The Postwar Career of NationBuilding in US Foreign Relations. In: FUKUYAMA, Francis. Nation-Building: 
Beyond Afghanistan and Iraq. Baltimore: John Hopkins University Press, 2007.

ELIAS, Nobert. O Processo Civilizador - vol. 2. Rio de Janeiro: Jorge Zahar, 1993.

ETZIONI, Amitai. A self-restrained approach to nation-building by foreign powers. International Affairs, n. 80, p.p 1-17, 2004.

EVANS, Gareth e SAHNOUN, Mohamed. The Responsibility to protect. Foreign Affairs, vol. 81, n. 6, 2002.

EVANS, Peter. O Estado como problema e solução. Lua Nova, 28/29, 1993.

EVANS, Peter; RUESCHEMEYER, Dietrich; SKOCPOL, Theda. Bringing the State back in. Cambridge: Cambridge University Press, 2002.

EWANS, Martin. Afghanistan: a short history of its people and politics. New York: Harper Collins Publisher, 2002.

FANZAL, Tanisha. State death in the International System. International Organization, vol. 58, n. 2, p.p. 311-344.

FAZEY, Cindy. Responding to the Opium Dilemma. In: ROTBERG, Robert. Building a new Afghanistan. Washington: Brookings Institution Press, 2007.

FERRO, Marc. História das Colonizações. São Paulo: Companhia das Letras, 1996.

FLOURNOY, Michèle. Nation-Building: Lessons Learned and Unlearned. In: FUKUYAMA, Francis. Nation-Building: Beyond Afghanistan and Iraq. Baltimore: John Hopkins University Press, 2007. 
FONSECA Jr., Gelson. As reformas da ONU: As propostas de Kofi Annan sobre segurança e operações de paz. In: BRIGADÃO, Clóvis e MELLO, Valerie de Campos. Diplomacia cidadã: Panorama Brasileiro de Prevenção de Conflitos Internacionais. Rio de Janeiro: Gramma, 2006.

FOOT, Rosemary et al. US Hegemony and International Organizations. Oxford: Oxford University Press, 2003.

FOREIGN POLICY. The Failed States Index. Foreign Policy, july/august, p.p. 54-63, 2007.

FUKUYAMA, Francis. O Fim da História e o Último Homem. Rio de Janeiro: Objetiva, 1994.

. Construção de Estados: governo e organização mundial no século XXI. Rio de Janeiro: Rocco, 2005.

Nation-Building: Beyond Afghanistan and Iraq. Baltimore: John Hopkins University Press, 2007.

. Nation-Building and the failure of Institutional Memory. In: FUKUYAMA, Francis. Nation-Building: Beyond Afghanistan and Iraq. Baltimore: John Hopkins University Press, 2007 a.

. Guidelines for future Nation-Builders. In: FUKUYAMA, Francis. Nation-Building: Beyond Afghanistan and Iraq. Baltimore: John Hopkins University Press, 2007 b.

FURTADO, Celso. Formação Econômica do Brasil. São Paulo: Companhia das Letras, 2007.

GADDIS, John Lewis. História da Guerra Fria. São Paulo: Nova Fronteira, 2005. 
GALTUNG, Johan. Cultural Violence. Journal of Peace Research, vol. 29, n. 3, p.p. 291-305.

GHALI, Boutros-Boutros. An Agenda for Peace: Preventive diplomacy, peacemaking and peace-keeping, 1992. Disponível em www.un.org. Acesso em 14/08/2006.

. Supplement to An Agenda for Peace, 1995. Disponível em www.un.org. Acesso em 14/08/2006.

GHANI, Ashraf; LOCKHART, Clare; CARNAHAN, Michael. Closing the sovereignty Gap: an Approach to State-Building. Overseas Development Institute, 2005.

GIDDENS, Anthony. O Estado-nação e a violência. São Paulo: EDUSP, 2001.

GIUSTOZZI, Antonio. Respectable Warlords? The Politics of State-Building in Post-Taleban Afghanistan. Crisis States Programme Working Paper 33, 2003.

Koran, Kalashnikov, and Laptop: The Neo-Taeban insurgency in Afghanistan. New York: Columbia University Press, 2007.

GOODSON, Larry. The Lessons of Nation-Building in Afghanistan. In: FUKUYAMA, Francis. Nation-Building: Beyond Afghanistan and Iraq. Baltimore: John Hopkins University Press, 2007.

GRIECO, Joseph. Understanding the problem of international cooperation: the limits of neoliberal institutionalism and the future of realist theory. In: BALDWIN, David. Neorealism and neoliberalism: the contemporary debate. New York: Columbia University Press, 1993.

HALL, John. Os Estados na História. Rio de Janeiro: Imago, 1992. 
HALL, Peter e TAYLOR, Rosemary. As três versões do Neo-Institucionalismo. Lua Nova, No. 58, p.p. 193-224, 2003.

HAMMOND, Thomas. Bandeira Vermelha no Afeganistão. Rio de Janeiro: Biblioteca do Exército, 1987.

HAMRE, John e SULLIVAN, Gordon. Toward Postconflict Reconstruction. The Washington Quarterly, vol. 25, n. 4, p.p. 85-96, 2002.

HELMAN, Gerald e RATNER, Steven. Saving Failed States. Foreign Policy, No. 89, p.p. 3-18, 1992.

HIPPEL, Karin. Democracy by Force: a renewed commitment to NationBuilding. The Washington Quarterly, vol. 23, n. 1, p.p. 95-112, 1999.

HIRST, Monica. Crise do Estado e Segurança Regional: Novos desafios para a América do Sul. In: CARVALHO, Maria Izabel e SANTOS, Maria Helena. 0 Século 21 no Brasil e no Mundo. São Paulo: EDUSC, 2006.

HOBBES, Thomas. Leviatã ou Matéria, Forma e Poder de um Estado Eclesiástico e Civil. São Paulo: Nova Cultural, 1997.

HOBSBAWM, Eric. Nações e Nacionalismo desde 1780. São Paulo: Paz e Terra, 1990.

A Era dos Extremos: o breve século XX. São Paulo: Companhia das Letras, 1995.

HOLSTI, Kalevi. The State, War, and the State of War. New York: Cambridge University Press, 1996.

HOLT, Victoria e MACKINNON, Michael. The Origins and Evolution of US Policy toward Peace Operations. International Peacekeeping, vol. 15, n. 1, p.p. 18-34, 2008. 
HOLZGREFE, J. L. e KEOHANE, Robert O. Humanitarian Intervention: Ethical, Legal and Political Dilemmas. Londres: Cambridge University Press, 2003.

HOURANI, Albert. Uma História dos Povos Árabes. São Paulo: Companhia das Letras, 1994.

HURREL, Andrew. Sociedade Internacional e Governança Global. Lua Nova, n. 46, 1999.

HUNTINGTON, Samuel P. O Choque de Civilizações e a recomposição da Ordem Mundial. Rio de Janeiro: Objetiva, 1996.

IGNATIEFF, Michael. Intervention and State Failure. Dissent, vol. 49, n. 1, 2002.

. Human rights, power and the state. In: CHESTERMAN, Simon et al. Making States Work. New York: United Nations Press, 2005.

JACKSON, Robert. Quasi-States: Sovereignty, International Relations and the Third World. Cambridge: Cambridge University Press, 1990.

JACKSON, Robert e ROSENBERG, Carl. Why Africa's Weak State persist: the empirical and the juridical in Statehood. World Politics, vol. 35, n. 1, p.p. 1-24, 1982.

JACKSON, Robert e Sorensen, Georg. Introdução às Relações Internacionais. Rio de Janeiro: Jorge Zahar, 2007.

JALALI, Ali. The Legacy of War and the Challenge of Peace Building. In: ROTBERG, Robert. Building a new Afghanistan. Washington: Brookings Institution Press, 2007. 
JOHNSON, Thomas e MASON, Chris. Understanding the Taliban and Insurgency in Afghanistan. Orbis, p.p. 1-19, 2006.

. No sign until the burst of fire: Understanding the PakistanAfghanistan Frontier. International Security, vol. 32, n. 4, p.p. 41-77, 2008.

JONES, Seth. The Rise of Afghanistan's Insurgency: State Failure and Jihad. International Security, vol. 32, n. 4, p.p. 7-40, 2008.

KALDOR, Mary. New and Old Wars: organized violence in a Global Era. Stanford: Stanford University Press, 1999.

KAPLAN, Robert. The Coming Anarchy. The Atlantic Monthly, February, 1994.

KARZAI, Hekmat. Strengthening Security in Contemporary Afghanistan: Coping with the Taliban. In: ROTBERG, Robert. Building a new Afghanistan. Washington: Brookings Institution Press, 2007.

KENNEDY, Paul. The Parliament of Man. The past, present, and future of United Nations. New York: Random House, 2006.

KEOHANE, Robert et al. After the Cold War: international institutions and state strategies in Europe, 1989-1991. Boston: Harvard University Press, 1993.

KEOHANE, Robert O. e NYE, Joseph S. Power and Interdependece. New York: Longman, 1989.

KHALIZAD, Zalmay e BYMAN, Daniel. Afghanistan: The consolidation of a Rogue State. The Washington Quarterly, vol. 29, n. 1, p.p. 65-78, 1999.

KOERNER, Andrei. Ordem política e sujeito de direito no debate sobre direitos humanos. Lua Nova, n. 57, p.p. 87-111. 
KRASNER, Stephen. Sharing Sovereignty: New institutions for Collapsed and Failed States. International Security, vol. 29, n. 2, p.p. 81-120, 2004.

KRUEGER, Anne. Government Failure in Development. Journal of Economic Perspectives, Summer, 1990.

LENINE, Vladimir. Sobre o Estado. In: LENINE, Vladimir: Obras escolhidas vol. 4. Lisboa: Avante, 1986.

LIMA, Maria Regina Soares de. Teses Equivocadas sobre a Ordem Mundial Pós-Guerra Fria. Dados, vol. 39, n. 3, 1996.

LITWAK, Robert (2007). Regime Change: U.S strategy through the prism of 9/11. Washington D.C: Woodrow Wilson Center Press.

MALONE, David. US-UN Relations in the UN Security Council in the Post Cold War era. In: FOOT, Rosemary et al. US Hegemony and International Organizations. Oxford: Oxford University Press, 2003.

MARQUES, Eduardo César. Notas Críticas à Literatura sobre Estado, Políticas Estatais e Atores Políticos. BIB, Rio de Janeiro, No. 43, 1997, p.p. 67-102.

MARSHALL, T. H. Cidadania, Classe social e status. Rio de Janeiro: Jorge Zahar, 1967.

MERLE, Marcel. Sociologia das Relações Internacionais. Brasília: UnB, 1981.

MESSARI, Nizar. Construção de Estados: Por que não funciona e como fazê-la funcionar. Contexto Internacional, vol. 26, n. 2, p.p. 287-316, 2004.

MIALL, Hugh et al. Contemporary Conflict Resolution. Oxford: Polity Press, 2005. 
MIGDAL, Joel. Strong Societies and Weak States. New Jersey: Princeton University Press, 1988.

MILLIKEN, Jennifer e KRAUSE, Keith. State Failure, State Collapse, and State Reconstruction: Concepts, Lessons and Strategies. Development and Change 33, p.p. 753-774, 2002.

MONTEIRO, Leandro. O Conceito de Estado Fracassado nas Relações Internacionais: Origens, Definições e Implicações Teóricas. Dissertação de Mestrado. São Paulo: Programa San Tiago Dantas de Relações Internacionais UNESP/UNICAMP/PUC-SP, 2006.

MORENO, Marta Fernandez. Propostas de democratização das Nações Unidas. Contexto Internacional. Rio de Janeiro, vol. 23, no 01, 200.

OTTAWAY, Marina. Rebuilding State Institutions in Collapsed States. Development and Change 33, p.p. 1001-1023, 2002.

PARIS, Roland. Human Security: Paradigm Shift or Hot Air. International Security, vol. 26, n. 2, p.p. 87-102, 2001.

At war's end: Building Peace after Civil Conflict. New York: Cambridge University Press, 2004.

PANNIKKAR, K. M. A dominação ocidental na Ásia: do século XV aos nossos dias. Rio de Janeiro: Saga, 1969.

PATRICK, Stewart. A return to Realism? The United States and Global Peace Operations since 9/11. International Peacekeeping, vol. 15, n. 1, p.p. 133-148, 2008.

PECEQUILO, Cristina. A Política Externa Norte-americana: Continuidade ou Mudança? Porto Alegre, UFRGS, 2003. 
PEI, Minxin, AMIN, Samia e GARZ, Seth. Building Nations: The American Experience. In: Nation-Building: Beyond Afghanistan and Iraq. Baltimore: John Hopkins University Press, 2007.

PEI, Minxin e KASPER, Sarah. Lessons from the past: the American on NationBuilding. Policy Brief Carnegie Endowment, p.p. 1-8, 2003.

POULANTZAS, Nicos. O Estado, o poder, o socialismo. Rio de Janeiro: Graal, 1985.

POULANTZAS, Nicos. Poder político e classes sociais. São Paulo: Martins Fontes, 1986.

PRZEWORSKI, Adam et al. O que mantém as democracias? Lua Nova, São Paulo, n. 40/41, p. 113-135, 1997.

PUREZA, José Manuel et al. Peacebuilding and Failed States: some theoretical notes. Oficina do CES n. 256, Coimbra, 2006.

. Do States Fail or are they pushed? Lessons from three former Portuguese colonies. In: $48^{\text {th }}$ Annual Convention of the International Studies Association (ISA), Chicago, 2007.

RASHID, Ahmed. Taliban: the story of afghan warlords. London, Pan Books, 2001.

REIS, Rossana Rocha. Os Direitos Humanos e a Política Internacional. Revista de Sociologia e Política, n. 27, p.p. 33-42, novembro de 2006.

ROTBERG, Robert. The New Nature of Nation-State Failure. The Washington Quarterly, 2002. 
. State Failure and State Weakness in a Time of Terror. Washington: Brookings Institution Press, 2003.

. When States Fail: Causes and consequences. New Jersey: Princeton University Press, 2004.

. Building a new Afghanistan. Washington: Brookings Institution Press, 2007.

RUBIN, Barnett. Lineages of the State in Afghanistan. Asian Survey, vol. 28, n. 11, p.p. 1188-1209, 1988.

. The Political Economy of War and Peace in Afghanistan. World Development, vol. 28, n. 10, p.p. 1789-1803, 2000.

. The Fragmentation of Afghanistan. New Haven: Yale University Press, 2002.

. Constructing Security for Sovereignty. Survival, vol. 47, No. 04, p.p. 93-106, 2005.

. Saving Afghanistan. Foreign Affairs, vol. 86, n. 1, 2007.

SAIKAL, Amin. Afghanistan's Ethnic Conflicts. Survival, vol. 40, n. 2, p.p. 114126, 1998.

. Modern Afghanistan: a History of Struggle and Survival. New York: I.B. Tauris \& Co. Ltd, 2004.

. Afghanistan's weak state and strong society. In: CHESTERMAN, Simon et al. Making States Work. New York: United Nations Press, 2005. 
SCHOULTZ, Lars. Estados Unidos: Poder e Submissão. São Paulo: Edusc, 2000.

SCHUMPETER, Joseph. Capitalismo, socialismo e democracia. Rio de Janeiro: Jorge Zahar, 1984.

SHEEHAN, Michael. International Security: an analytical survey. Londres: Lynne Rienner, 2004.

SILVA, Carlos Eduardo Lins. Doutrina Bush foi gerada há dez anos. Política Externa, Vol 2, no. 3, dezembro-janeiro-fevereiro 2002/2003.

SKOCPOL, Theda. Estados e Revoluções Sociais: Análise comparativa da França, Rússia e China. Lisboa: Editorial Presença, 1985.

SMITH, Anthony D. Criação do Estado e Construção da Nação. In: HALL, John. Os Estados na História. Rio de Janeiro: Imago, 1992.

SORENSEN, Georg. War and State-Making: Why doesn't it work in the Third World? Security Dialogue, vol. 32, n. 3, p.p. 341-354, 2001.

STARR, S. Frederick. Sovereignty, Legitimacy in Afghan Nation-Building. In: FUKUYAMA, Francis. Nation-Building: Beyond Afghanistan and Iraq. Baltimore: John Hopkins University Press, 2007.

TANNO, Grace. A Contribuição da Escola de Copenhague aos Estudos de Segurança Internacional. Contexto Internacional, vol. 25, n. 1, 2003.

TEIXEIRA, Carlos Gustavo Poggio. O Pensamento Neoconservador em Política Externa nos EUA. . Dissertação de Mestrado. São Paulo: Programa San Tiago Dantas de Relações Internacionais UNESP/UNICAMP/PUC-SP, 2007. 
TEIXEIRA, Tatiana. Os Thinks Tanks e sua influência na política externa dos EUA. Rio de Janeiro: Revan, 2007.

THIER, J. Alexander. The Politics of Peace-Building. Year One: From Bonn to Kabul. In: DONINI, Antonio et al. Nation-Building Unraveled? Aid, Peace and Justice in Afghanistan. Bloomfield: Kumarian Press, 2004.

TILLY, Charles. Coerção, Capital e Estados Europeus. São Paulo: EDUSP, 1996.

TILLY, Charles. War making and State making as Organized Crime. In: EVANS, Peter; RUESCHEMEYER, Dietrich; SKOCPOL, Theda. Bringing the State back in. Cambridge: Cambridge University Press, 2002.

TSCHIRGI, Neclâ. Post-Conflict Peacebuilding Revisited: Achievements, Limitations, Challenges. In: WSP INTERNATIONAL/ IPA PEACEBUILDING FORUN CONFERENCE. New York, 2004.

UNDOC. Afghanistan Drug Industry: Structure, Functioning, Dynamics, and Implications for Counter-Narcotics Policy. Washington: World Bank, 2007.

UNITED NATIONS. A more secure world: our shared responsibility. New York: UN, 2004.

VELASCO e CRUZ, Sebastião. Estado e Mercado: a OMC e a constituição (incerta) de uma ordem econômica global. Revista Brasileira de Ciências Sociais, vol. 20, n. 57, 2005.

VILLA, Rafael Antonio Duarte. Da crise do Realismo à Segurança Global Multidimensional. São Paulo: Annablume, 1999. 
Quatro teses sobre a política de segurança dos EUA para a América do Sul. Tese de Livre-docência. São Paulo: USP, 2007.

VILLA, Rafael Antonio Duarte e REIS, Rossana Rocha. A Segurança Internacional no Pós - Guerra Fria: um balanço da Teoria Tradicional e das novas agendas de pesquisa. BIB, São Paulo, no. 62, 2ํㅗ semestre, p.p. 19-51, 2006.

VIZENTINI, Paulo. As relações internacionais da Ásia e da África. Petrópolis: Vozes, 2007.

XAVIER, Erwin Pádua. Construção do Estado, Comunidade Política e Segurança: o caso do Uzbequistão na Ásia Central Pós-Soviética. Dissertação de Mestrado. Rio de Janeiro: IRI/PUC-RIO, 2006.

ZAKARIA, Fareed. Writing Prose for a New Term. Newsweek, November 15, 2004, p. 13.

ZARTMAN, I. William. Collapsed States: the Disintegration and Restoration of Legitimate Authority. Colorado: Lynne Rienner, 1995. Introduction: Posing the problem of State Collapse. In: ZARTMAN, I. William. Collapsed States: the Disintegration and Restoration of Legitimate Authority. Colorado: Lynne Rienner, 1995 b.

WEAVER, Olef et al. Security: a new framework for analysis. London: Lynne e Rienner, 1998.

WALLANDER, Celeste e PROKOP, Jane. Soviet Security Strategies toward Europe: after the Wall, with their backs against it. In: KEOHANE, Robert et al. After the Cold War: international institutions and state strategies in Europe, 1989-1991. Boston: Harvard University Press, 1993. 
WALLERSTEIN, Immanuel. The Modern World-System: Capitalist Agriculture and the Origins of the European World-Economy in the $16^{\text {th }}$ Century. New York: Academic Press, 1976.

WALTZ, Kenneth. Globalization and Governance. PS Online, December 1999.

. O Homem, o Estado, a Guerra: uma análise teórica. São Paulo: Martins Fontes, 2004.

WALZER, Michael. Guerras Justas e Injustas. São Paulo: Martins Fontes, 2003.

WATSON, Adam. A evolução da sociedade internacional. Brasília: UnB, 2004.

WEBER, Max. Ciência e Política: Duas vocações. São Paulo: Martin Claret, 2004.

. Economia y Sociedad. México: Fondo de Cultura Económica, 2004b.

WOHLFORTH, William C. The Stability of a Unipolar World. International Security, vol. 24, No. 1, 1999.

WOODWARD, Susan. Fragile States: Exploring the Concept. In: STATES AND SECURITY LEARNING GROUP at the PEACE AND JUSTICE MEETING. Rio de Janeiro, 2004.

WRIGHT, Lawrence. O Vulto das Torres. São Paulo: Companhia das Letras, 2007. 